\title{
Pareceres jurídicos en asuntos de indias
}

Desde el momento en que Fray Antonio Montesinos alzó su voz en contra de los abusos que se cometían contra los indios en la Isla Española. en la Dominíca precedente a la fiesta de Navidad del año 1511, comenzó lo que acertadamente se ha llamado la lucha por la justicia en América. Esta lucha no tuvo tregua, puede decirse, en los años que se siguieron a la protesta del fraile dominico $y$, cuando después de las leyes de Burgos, dadas en 1512, abonanzó un tanto el combate, vino Las Casas a encender de nuevo la pelea en 1517 y ésta no cesó, culminando en el fámoso debate entre Ginés de Sepúlveda y Fray Bartolomé, en los años 1550 y 1551.

Desde el Perú habían terciado en la contienda, en defensa de los indios, Fray Domingo de Santo Tomás, corresponsal de Las Casas y con el cual mantuvo estrecha comunicación y su hermano de hábito Fray Tomús de San Martin, que con libertad cristiana escribía estas líneas sobre los bienes adquiridos por los conquistadores: "Los primeros conquistadores e descubridores, según verdadera cristiandad y católica teología, se debe tener por averiguado que cuanto poseen e han llevado por tributos de los dichos indios, que ansi descubrieron e conquistaron son mal llevados e que no los pueden llevar ,porque no guardan las condiciones de buena guerra ni conquistaron, guardando ley natural, divina ni humana, canónica ni civil, por seguir su propio interese..., digo que los primeros conquistadores fueron tan amigos de su interese que en todo lo que hicieron iba delante el interese, de suerie que ellos propios con sus hurtos y robos justificaron la causa a los propios naturales, para justamente defenderse y no dar crédito a cosa que dijeren. E ansi subjetaron la tierra, robando y matando y no guardando, no digo ley divina pero ni aun natural...'. Fray Tomás y muchos otros como él salieron en defensa de la justicia y no temieron lanzar su terrible veredicto $\alpha$ la faz de los mismos conquistadores.

Estos frailes y un grupo reducido, es verdad, de colonizadores, no aguijoneados excesivamente por la sed del oro, encarnaron el propósito civiltzador y cristiano de la conquista $\mathrm{y}$, al abogar por los derechos del indígena, impidieron que ella diese por resultado su destrucción. Eran dos tendencias contrarias las que encaminaban a los españoles a las Indias, la una se inspiraba en un ideal muy humano y egoista: Ia adquisición de fama y de riquezas; la otra obedecía a impulsos más nobles y generosos y se proponía la expansión de la fé verdadera y de la civilización cristiana. Pero la lucha

(1) C.D.I.H.A. Tom. 7, p. 349. 
no estalló tan sólo entre los dos bandos extremos sino que se entabló dentro de cada individuo, por que el español, como una esfinge de dos coras, no era insensible al ideal cristiano y tampoco lograba desprenderse del afán de las riquezas. Legalista por instinto y por tradición trató de justificar sus actos y su posición ante el indígena sometido y hubo de recurrir a teólogos y juristas. La intervención de estos pudo ser en muchos casos, como en el ya citado de Fray Antonio Montesinos ó en el de Las Casas, una voz de protesta, pero en otros no sirvió sino para acallar escrúpulos o poner los fundamentos de un derecho que aparecía dudoso e incierto.

Los dominícos, parte por la influencia que ejercían en la España del siglo XVI, parte por la sólida formación científica de sus miembros, fueron los que más se distinguieron en esta lucha y es digna de todo elogio la actitud que adoptó la mayor parte de ellos, enfrentándose gallardạ y serenamente al mismo soberano. Con el andar del tiempo y el afianzamiento del absoIutismo, unido todo ello a las ideas exageradas que se tenían de la autoridad real, para muchos vino a constituir una razón de peso la voluntad del Monarca y de ello se hallan trazas más o menos claras en los autores que escribieron sobre la materia, ya a partir del último tercio del S. XVI. Es indudable, como se ha dicho², que si en los trailes de Santo Domingo se descubre esa libertad santa en el hablar y, al mismo tiempo, esa cudacia en el discurrir, hay que atribuirlo a su cabal conocimiento de la teología. Por eso no fueron los juristas, aun eclesiásticos, los que sentaron las bases del derecho indiano sino los teólogos que poseían una ética superior. De ahí que el estudio de las obras de estos sea de capital importancia para una exacta interpretación de la historia de América, en la cual van a medir sus aceros dos fuerzas o dos tendencias que, hoy como ayer, están en perpetua liza, el materialismo grosero y el espiritualismo cristiano.

De la obra y del pensamiento de los Dominícos se ha escrito no poco, pero no sucede otro tanto por lo que hace a la Compañía de Jesús. Es cierto, que esta Orden llegó a América la postrera y cuando ya la controversia sobre el derecho de conquista y otras relativas a asuntos de Indiasi ó habían llegado a una solución o se habían entibiado, pero con todo no les faltó ocasión de intervenir. Si en la lucha con el Protestantismo la Compañía constituyó la vanguardia de la Iglesia, en América no podía menos de salir a la defensa de los indios, dado que su establecimiento en estas tierras obedecía ante todo al propósito de convertirlos a la fé. Orden misionera, por excelencia, sobre todo en estos países, pero al mismo tiempo, amaestrada en las lides del saber y con indudable reputación de sabia, tenía por fuerza que ponerse del lado del indígena oprimido y sin defensa. $Y$ lo hizo cuantas veces se hizo necescria su intervención.

Son conocidas las ideas de un José de Acosta, uno de los primeros en concebir un plan misional adaptado a la realidad, las de un Luis de Valdivia cutor de la guerra defensiva contra los Araucanos y de un Antonio Ruiz de Montoya, el incansable apóstol $y$ defensor de los guaraníes, pero otros muchos nombres yacen olvidados y es oportuno conocerlos, no sólo por el valor intrínseco que puedan tener sus apreciaciones sino porque ellas nos revelan cuál era la mente de los jesuitas acerca de los problemas que aquí se suscitaban y el influjo ejercido por ellos en los gobemantes y en las leyes. En este trabajo hemos recogido algunos pareceres sobre las encomien-

(2) Venancio D. Carro O.P. Ia Teología y los Teólogos Juristas Españoles ante la Conquistơ de Amdérica. Madrid, 1944. Tom. I, Introducción. 
das, la mita, el servicio personal o las ordenanzas dadas para el buen régimen de los indios y hemos prescindido de citar los Memoriales de los Padres antes citados, por ser más conocidos. Nos ceñimos, además, a los Jesuitas del Perú, provincia que en los principios alcanzó a tener los mismos límites que el Virreinato, fraccionóndose después en las del Paraguay, Quito y Chile y oun la misma Nueva Granada.

Fué San Francisco de Borja, el célebre Duque de Gandia y Tercer General de la Orden fundada por San Ignacio, el que envió a la Ámérica Española los primeros jesuitas, aunque ya en vida del Fundador se había tratado de esta misión. El 28 de Junio de 1566 se embarcaban en Sevilla los PP. Pedro Martínez. Juan Rogel y el Hermano Francisco de Villarreal, con destino a la Florida, por donde los había solicitado con instancia el Adelan. tado Pedro Menéndez de Avilés ${ }^{3}$. Aun cuando aquellas tierras distaran tanto del Perú, el pensamiento del General no era otro sino que esta misión dependiera de la Provincia que se había de fundar en la Nueva Castilla, haciendo poco caso, como entonces se hacía, de las muchas lequas que separaban unas tierras de otras. Al siguiente año, en 1567, se hacían a la vela desde Sanlúcar de Barrameda, los ocho jesuitas destinados al Perú, teniendo a su frente al P. Jerónimo Ruiz del Portillo. El 28 de Marzo de 1568 arribaban al Callao y el primero de Abril hacían su entrada en Lima, donde fueron recibidos con sigular alborozo. Pronto empezaron $\alpha$ ejercitar sus minisierios, ya sea con los españoles ya sea con los indios y negros y con tanto truto y aceptación que en Abril del siguiente año escribía el Oídor Gregorio Gonzalez de Cuenca a San Francisco de Borja que era para alabar a Dios ver las mudanzas que entre indios y españoles habían logrado con su predicación los de la Compañía.

No dejaban de presentárseles casos difíciles y de ello nos dá una prueba este párrafo de carta del P. Provincial, Jerónimo Ruiz del Portillo a San Francisco de Borja: "Deseamos mucho tener de Vuestra Paternidad la resolución de cómo nos avremos con los encomenderos, conquistadores y mercaderes destas tierras, porque en un Concilio Provincial que se hizo en la ciudad de los Reyes de Obispos y letrados de todas religiones ha hecho unos decretos y modo que parece pío y seguro $\mathrm{y}$ seguir lo del Concilio Provincial es suficicnte causa para que nadie se escandalice de nosotros $y$ nosotros quedemos seguros. Ay se invia a V.P. con otro modo de la Orden de San Augustin que $\alpha$ sus frailes tenia dado". "El Concilio aqui citado no era otro sino el de 1567, convocado por Fr. Jerónimo de Loayza y en él se aprobaron unos "Avisos Breves para todos los confesores destos Reynos del Perú, cerca de las cosas que en él suele aver de más peligro y dificultad...". Estos avisos que suscribieron a una con el Arzobispo Loayza los Provinciales de Santo Damingo, Fray Gaspar do Carvajal, de San Francisco, Fray Francisco de Morales, el Vicario Provincicl de La Merced, Fray Miguel de Orenes y los Priores de Santo Domingo, Fray Tomás de Argumedo, de San Agustín, Fray Andrés de Ortega, los canónigos, Bartolomé Martínez, Arcediano, Domingo Marquina, Chantre y los PP. Fray Ambrosio Guerra O.P. Fr. Gerónimo de

(3) V. mis estudios: Orígenes de la Provincia Jesuítica del Perú. Los Mártires de la Florida. Lima, 1940 y Jesuitas del Perú. Lima, 1941. Parte 1. Cap. 1.

(4) Arch. Romano S.J. Perú. Historia. Carta tha. en Los Reyes, 2 de Enero de 1568. 
Villacarrillo, O.M. y Fr. Pedro de Cepeda, O.S.A. fueron redactados y firmados algunos años ontes del Segundo Concilio Limense, a 11 de Marzo de 1560 y fueron la réplica de lo que con igual motivo se había hecho en Méxdico on las llamadas Iuntas Apostólicas.

Ell P. Portillo juzgó conveniente adoptar las reglas que en ellos se daban para confesar encomenderos o ayudarles a disponer sus testamentos con buena conciencia, hecho que conviene tener en cuenta para explicar el porqué de algunas disposiciones testamentarias de los primeros conquistadores, como Nicolás de Rivera, Francisco de Fuentes y Juan Sierra de Leguizamo, pues dichas reglas no databan de entonces sino que ya se las habian pedido a Fray Bartolomé de las Casas algunos frailes de su Orden y el Obispo las había redactado y sometido al juicio de algunos varones doctos y maestros de Teología del célebre convento de San Esteban de Salamanca. ${ }^{5}$ Como la autoridad de los que habían extendido estos avisos era grande y la experiencia los había dado por buenos. Portillo no dudó tomarlos como norma en sus re!aciones con los encomenderos y de ahi que el 12 de Enero de 1569 escribiera a S. Francisco de Borja: "En lo de los encomenderos y conquistadores y los demás en que podría aver escrúpulo, seguimos el orden que aquí en el Concilio Provincial se ha dado y el que por el señor arzobispo se nos dá que es bien escrupuloso en esto y ansi nadie tiene que desedificarse".

Estos avisos los vamos $\alpha$ reproducir aquí, tomándolos del ejemplar que el mismo P. Portillo remitió a Roma, pero en el cual se advierten algunas variantes que conviene señalar. En primer término preceden a los A visos unas preguntas que los Confesores han de hacer a los encomenderos, tomados de la Real Cédula de su encomienda, pues, como era natural, lo primero de todo era averiguar si cumplían con aquella a que estaban obligados por el tenor da la misma cédula. Luego, después de los Avisos, se trascribe la resolución al caso de conciencia que se propuso en el Colegio de Lima en el año 1570, sobre las obligaciones de los encomenderos, supuesta la legitimidad de su encomienda y al cual satisfizo el P. Bartolomé Hernóndez, como se verá. Todo esto nos permite conocer, por una parte, cuál era el concepto ético jurídico de los Jesuitas en el asunto de las encomiendas $y$, de otro lado, la escrupulosidad con que se procedía en materia tan espinosa ${ }^{6}$.

(5) V. el opúsculo de Las Casas, titulado: "Aquí se contienen unos avisos y Reglas para los confessores que ayeren contessiones de los españoles que son $\circ$ han sido en cargo a los indios de las Indias del Mar Océano, colegidas por el Obispo de Chiapa"... Sevilla, en casa de Sebastión Trugillo, impressor de Libros. 1552. Reproducción facsimilar del mismo en el Tom. III de Libros Ramos Americanos pub. por el Instituto de Investigaciones Históricas de la Fac. de Filosofía y Letras de Buenos Aires. Buenos Aires, 1924.

(6) Copias de estos avisos debieron circular por todo el Perí. Una de ellas sirvió al P. Damingo Angulo para el artículo que publicó en la Revista del Archivo Nacional del Perú (Tom. I, p. 82 y s. Lima, 1920) bajo el título: 'Instrucciones de los PP. Dominícos para contesar conquistadores y encomenderos", tomándola probablemente del Archivo de Santo Domingo de esta ciudad. No advirtló, sinembargo, que se trataba de una casi textual trasotripción del Tratado de Las Casas que hemos citado. Estos Avisos difieren bastante de los aprobados por el Arzobispo Loayza, pero tampoco podemos decir que estos últimos han permanecido inéditos hasta ahora. En 1947 el P.A. Tibesar O.M. los reproducía en la revista "The Americas", (Vol. III, No 4. April, 1947). En la introducción asegura que dichar copia procede del Archivo de San Francisco de Lima (Registro 2, p. 2, Doc. 30) y en ella se dá a este documento el título de 'Instrucciones para los confesores de conquistadores dadas por el Arzobispo de Lima en 1560". Por desdicha la copia utilizada o, 


\section{III \\ Preguntas para los Contesores de Encomenderoe}

Las preguntas que se han de hazer a los encomenderos que se confiesan por razón de las encomiendas de sus indios podrán ser las siguientes, las quales son sacadas de las que en la cédula de encomienda del Rey se les manda y de lo que en ella y en la tasa se les prohibe.

Primeramente se presupone que ay tres géneros de encomenderos: unos, los primeros conquistadores que son los que se hallaron en Caxamal ca, al principio, donde mataron al Inga y obieron gran cantidad de oro y plata, de lo qual están obligados a restitución in solidum. ${ }^{7}$ Destos ar muy pocos y estos los repartimientos que tubieron por encomienda del Marqués Pizarro fué sin tasa, más de que se les permitió que se sirviesen de los indios y les llevasen lo que buenamente pudiesen darles y servirse dellos de ser vicio personal, como si fueran esclarvos, no pagándoles su trabaxo y llevábanles todos los tributos que podían, no dexándoles oro ni plata, ganados ni otra cosa de que ellos se pudiesen aprovechar y hechávanlos a las minas de ciento en ciento, como si fueran esclavos, donde morían muchos y llevábanlos cargados a las guerras, donde quiera que iban y hazían grandes crueldades en ellos y morían muchos destos. Se dize que estón obligados a restitución de lo que así les llevaban y a todos los daños, por ser tan exorbitantes y porque no les davan doctrina ni policia ni hazíam otro beneficio, como se les mandava en la encomienda, aunque podrá llevar algo porque sustentavan la vezindad.

Los segundos son los que hizieron la tasa primera que fué la del hic. Gasca, esta se entiende fué agravada contra los indios y con esto se entiende que muy pocos la guardavan y así llevaban más de los que se les mandava dar en ella y no les davan doctrina bastante instrucción en las cosas que les mandan en las encomiendas y así se entiende que están obligados a restitución de todo lo que llevaron excepto lo que gastaron para su honesta sustentación.

Los terceros son los retasados que son los que an sido últimamente tasados por los Virreyes o oidores y estos si la tasa que les an tasado la pueden pagar sus indios de manera que no vengan en disminución y tengan sustentación cómoda para si y para sus hijos y mujeres y donen doctrina suficiente y cumplan con lo demás que se les manda en la cédula de encomienda y tasa que de los indios tienen pueden llevar esta tal tasa con buena conciencia y si exceden desto, no porque sea última tasa podrán llovarla, porque siempre se entiende que la tasa será justificada quando es contorme al alvedrio de buen varón.

como se deja entender en algunos casos, la trascripción dejan bastante que desear y ex algunos casos hacen ininteligible la lectura.

Si a estas copias existentes, como se vé, en los conventos de Santo Domingo, San Francisco $y$ en el Colegio de la Compañía, añadimos la que atribuye el P. Portillo a ló Agustinos, se llega a la conclusión de que la Iglesia uniformó su parecer en esta materia y veló de esta manera porque se respetaran los derechos de los indígenas, tal y co. mo eran reconocidos por la ley.

(7) Es decir, integramente. 


\section{Preguntas sacadas de la cédula de encomienda:}

1.- Si a llevado más tributos de los que en la tasa le mandan dar, como ariba se a declarado.

2.- Si se a servido de los indios de algún servicio personal en su casa o haziendas por si o por interposita persona.

3.-Si a tratado bien a sus indios y procurado su conservación y defensión y dádoles doctrina bastante $\mathrm{y}$ instruídolos en buena policía, ley $\mathrm{na}$ tural y si a sustentado la vezindad con armas y cavallo como se le manda en la encomienda que dellos tiene.

4.-Si a guardado el juramento que por causa de la encomienda hizo, conde juró guardar fidelidad al Rey, a sus governadores en su nombre $y$ darles buen consejo quando le fuere pedido $\mathrm{y}$ guardar secreto $\mathrm{y}$, en tiempo de guerra, acudir al servicio del Rey; si a sabido de alguna alteración ó bullicio que se aya levantado donde el bive y no a avisado dello al que govierna.

\section{Las preguntas que dió el Obispo de los Charears en esta materia:}

1.-Si antes de la tasa llevaron más tributo ó (roto) de aquellos en que fueron después tasados, porque el Lic. de la Gasca que vino a governar al principio se los encomendó con condición que no les llevasen más de lo que buencmente pudiesen darles.

2. - Si las tasas que dan los indios las pueden buenamente pagar, quedándoles lo necesario para si y sus casas y si dan de tasa de las cosas que tienen en sus tierras o si salen fuera della a buscarlas.

3.-Si a ocupado a los indios en guardar ganados o en beneficiar chacras o otras haziendas suyas o embióndolos a Potosi o $\alpha$ otras partes, sin darles la paga en su mano y si les dá tanto como los otros que no son encomenderos suelen dar y si la paga es en plata ó en otras cosas que no las quieren los indios; si a los yanaconas que les sirven pagan su soldada.

4. -Si en la sementera que por la tasa mandan hazer a los indios en sus tierras para los encomenderos ocupan más indios y más tiempo porque sean mejores y si les toma la mejor tierra para ellos.

5.-Si los encomenderos ponen estanciero en sus granjas y que haga trcioajar a los indios y si lleva el estanciero parte de los frutos que se cogen porque por esta razón las trabajan más.

6.-Si tienen chácaras de los indios, aunque sea con autoridad de justicia y sean de las del inga sin pagarlas a los indios en cuyo término están. porque las del inga eran para los tributos de comida que le davan y quitándoselas cargan los tributos que le dan sobre las propias tierras de los indios.

7.-Si por ocupar los indios en sus haziendas el encomendero no les queda tiempo para sembrar sus comidas ni para entender en lo que conviene a sus casas.

8.-Si quando el encomendero vá a su repartimiento, sus amigos o faniliares pagan a los indios el servicio de yerva o leña como ó las demás cosas que a ellos toman como las avian de pagar a otros que no fueran sus indios.

3.-Si paga el servicio a los indios que le sirven al estanciero o $\mathrm{ma-}$ yordomo y los mitayos que le dan y si paga a los mensajeros que imbia con cartas o con otras cosas. 
10.-Si los indios que ocupa o trae alquilados los ocupa de monera que no les quede tiempo para entender en saber la doctrina y las demás cosas que tocan a su alma.

11.-Si tiene los sacerdotes necesarios para doctrinar sus indios, con. forme a la distancia de la tierra de su repartimiento y a la cantidad dellos y por aora parece que para cada 400 indios casados se deve poner su sacerdoie, estando lugares cómodos y no muy apartados y llámanse suficientes de doctrina quando por falta de sacerdote no se muere ningún indio ni aduito sin los sacramentos necesarios.

12. - Si el tiempo pasado a tenido bastante doctrina conforme a lo susodicho, donde no a de restituir a los indios, por lo menos la cantidad que se avia de gastar en la doctrina aunque aya dejado de ponerlo por falta de no hallar sacerdotes.

13. - Si a pagado el salario de doctrina al sacerdote y si por no pagarle quando le devía pagar a dexado el sacerdote la doctrina y hecho gastos en venir a cobrarla a la ciudad, porque en tal caso estará obligado el enco. mendero al daño que viene $\alpha$ los indios por la ausencia del sacerdote y $\alpha$ los gastos que el sacerdote hizo en venir a cobrar su hazienda.

14. - Si el año que los indios no cogen por esterilidad la comida acostumbrada les lleva por entero la tasa y si de aquel año no se la lleva le harce pagar otro año porque conforme a la tasa el año steril no han de pagar los indios sino lo que buenamente pudieran.

15. - Si quando iba a la guerra o a otras artes llevaba indios con cargas de comidas y otras cosas, si pagó el llevar de las dichas cargas a los indios que las llevaban.

16. - Si a hecho conquistas, si los daños que hizo él y sus yanaconas, criados y negros $y^{\prime}$ las muertes y robos, anse de guiar en esto por las reglas generales de bello. 8

17. - Si por tener ganados muchos en sus repartimientos hazen daños en las sementeras de los indios y si por temor destos daños dexan los indios de hazer sus sementeras o las hazen en tierras más lexos y peores.

18. - Si procura saber el encomendero los agravios que los caciques hazen a sus indios en repartir los tributos y los demás servicios de la comunidad, porque está obligado a saberlo y procurar que se remedie y lo mismo esta obligado a saber si tienen los indios bastante doctrina, porque no siendo tal es obligado a avisar al prelado para que le provea.

19. - Si conciente el encomendero que los que de derecho no son caciques tengan los cacicazgos usurpados a los caciques naturales, porque los otros que no lo son no sólo les hazen cobrar mejor sus tributos pero les permiten otras granjerías prohibidas.

Jhs.-Avisos Breves para todos los confesores destos Reynos del Piru cerca de las cosas que en él suele aver de más peligro y dificultad, fecho por mandado y en presencia del Iltmo. y Revmo. Sr. Dn. Fr. Hierónimo de Loayza, primero Arzobispo de los Reyes, por todos los prelados y theologos que en esta corte residen $y$ de otras partes an acudido."

(8) El texto dice: por las guerras generales: debe decir: por las reglas generales de bello, esto es, de la guerra.

(9) Al pié, de otra letra: Instructio pro confessariis Provinciae Peruanae y más abajo: Missio Peruana. 
El llustríssimo y Rermo. Sr. Dn. Fr. Jerónimo de Loayza, primero arzobispo de los Reyes, movido con sancto celo de la salvación y remedio de las almas y deseando dar buena quenta dellas y procurando quitar las impedimentos que el demonio les suele poner para conocer el camino de la verdad que Jesucristo nos vino a enseñar, acordó de buscar el mejor y más sancto y eficaz remedio que para aquesta conquista espiritual pudo aber que es la conformidad y concordia de opiniones de parte de los ministros de Dios, a cuyo cargo están las conciencias de los fieles cuyas confesiones oyen, los quales ministros con esta unión serían bastantes para destruir el reyno del demonio fácilmente, pues vemos que la gente de cualquier exercito, por mucha $y$ fuerte que sea, es fácilmente vencida $y$ desbaratada no siendo $\alpha$ una y en la cuerda de la ballesta aquellos hilos de que se compone, cada uno de por si tiene poca o ninguna fuerza y muchos juntos son bastantes para doblar un fortísimo acero, desta manera los ministros de Dios y. confesores harán hazienda y ternan cierta la victoria y será argumento que se rigen por el espíritu de Dios y no por el suyo, sienda todos a una, pues como dize Sant Pablo: Cristo no está dividido, para que con esta concordia se comienze la conquista contra el demonio, desde luego haziendo los predicadores y confesores con esta unión, en el reyno que por tan suyo tiene el demonio, una entrada con que sea desposeído del.

El señor arzobispo juntó muchos prelados, asi provinciales como otros theologos de las quatro Ordenes, los quales, en muchas congregaciones que delante de su señoría reverendíssima tuvieron, acordaron entre todos de dar los avisos que convienen a los confesores para alumbrar las conciencias de los que con ellos se vienen a confesar, acerca de los descargos a que estón obligados los que conquistaron esta tierra como cerca de la obligación que tienen los encomenderos de yndios y otras cosas en que podrían los confesores tropezar y los penitentes yr defraudados en todo el caudal del ónima.

Las cosas que determinaron son las siguientes:

Primeramente se determinó que todos los conquistadores son obligados a restituir todo el daño que hizieron en todas las conquistas y guerras que hasta agora se an hecho, adonde ellos se hallaron por los capitanes $\mathbf{Y}$ oficiales $\mathrm{y}$ gente de guerra que pudieron ver la ynstruction de Su Magestad $y$ entender el órden que mandava tener, al qual devian mirar e ynformarse si la guerra era justa y porque no la guardaron no se pueden escusar de restituir todo el dicho daño in solidum ${ }^{10}$ cada uno de los dichos $y$ de otra monera no los pueden absolver.

Item son obligados in solidum $y$ no se pueden escusar en alguna manera los que dudaron si la querra era justa o no y no se informaron de quien les pudiera dezir la verdad sino con duda si era lícita o no la guerra se quisieron ir allá.

Item se determinó que si uvo algunos que pensaron que era justa $y$ buena, lo qual no es de creer que oviese alguno destos, pero si lo ovo que con esta ignorancia le parescía que podía quitar a los yndios lo que tenían, por ser idólatras o comer carne umana o sacrificar hombres o por otras razones semejantes o aparentes que les moviesen a pensar ser la guerra lícita $y$ assi mesmo tenía intención que si supiera u oyera que esta guerra era injusta se desistiera della, esta tal, porque no avia la ynstrucción de Su Magestad, que no permite se les hiziese la guerra como se les hizo, serán obligados a restituir la parte que les cupo de los robos, no la aviendo gastado

(10) V. nota 7. 
durante aquel tiempo que creian ser buena la guerra y no tenían quien le enseñase lo contrario, $\alpha$ quien deviesen creer, pero si quando aquello gas: taron en el tiempo ya dicho por gastallo de su hazienda ahorraron otro tmto, en tal caso son obligados a restituir todo aquello en que se hizieron más ncos, que será todo aquello que avian de gastar, si no comieran y gastaran de lo ajeno.

Item se determinó que la restitución de lo que se ovo en las conquistas y de los daños que se hizieron se a de hazer luego, cunque sea con da. ño de su estado, reduciéndose de cavallero a plebe $y$ en el gasto, por ser avidos por medio tan ilícito, como es hurto o rapiña; no se deven absolver los tales si primero no restituyeren $y$ no constando de las personas $\alpha$ quien se hizo el daño y robos, por ser ya muertos o no se poder aver, podráseles: dexar algo por via de pobres, conforme a la necesidad que tuvieren, para sustentar sus personas, según el provecho que hizieren en la república o en. el aumento y conservación de los indios y esto con parescer del Obispo de su àócesis $y$ no aviendo Obispo del confesor prudente y lo demás emplearlo y darlo para cosas que sean en beneficio de la república de los indios, que principalmente fueron damnificados de manera que resciban dello beneficio temporal y espiritual, según el parescer $y$ buen juizio del Obispo. donde se oviere de hazer la tal restitución.

Item se declaró que estos dichos bienes de conquistadores, por ser tan injustamente avidos, aunque no se sepan ciertas las personas a quien se deven, no admiten otra composición más de la dicha que es dexar algo al que tiene los dichos tales bienes por via de pobre, como dicho es, por el arbitrio del Obispo y que en estos bienes puede adquirir dominio como si a otro cualquier pobre se diesen y no está obligado a restitución de aquella parte que para su sustentación se le dió, sino fuese debiendo más de lo que el susodicho restituyó, que entonces todo lo que tuviese y adquiriese más de lo que a menester para sustentarse será obligado a restituir hasta satisfazer lo que deve o si no según su facultad lo que pudiere.

Item se declaró y determinó que por lo necesario para su persona se entiende lo que moderadamente $\alpha$ menester para si y para, su mujer y hijos, considerada la calidad de la persona y aprovechamiento en la república y conservación de los indios, de tal suerte que no aya fraude ni dolo en ello ni superfluidad en el tratamiento de su persona, lo qual se le a de dar en el entretanto que busca alguna manera de bivir de que se sustente.

Item se determinó que los hijos y sucesores o herederos de los taleg están obligados a restituir todo lo que heredaron de los dichos conquistadores de manera que si el dicho conquistador devia 20,000 pesos y el heredero ovo 10,000 está obligado a restituir 10,000 y si heredá una chácara que el padre conquistador hizo, la qual no valía más de 5,000 pesos (no estará obligado el heredero a los frutos de la dicha chácara sino a los 5,000 pesos) porque fundus fructificat Domino, que quiere dezir que la heredad dá frutos para su poseedor, de manera que si un usurero con 5,000 pesos ganados $\alpha$ usura comprase una chácara no deviendo más de aquellos 1,000 pesos no estará obligado a los frutos de la tal chácara, de esta manera se entiende el caso sobredicho.

Item se determinó que la mujer del conquistador que supo o dudó y no se informó que todos los bienes de su marido eran robados $y$ estavan obligados a restitución que no podrá llevar la mitad de lo multiplicado, siendo las cosas de su marido cosas que tructifican como ganados, guertas, heredades, pero si fuesen bienes que no fructifican, como oro, plata, puedel gozar de la mitad de lo multiplicado con la yndustria de su marido o suya. 
Item se determinó que esta tal si no tiene otros bienes de que pasor la vida que podrá vivir de los tales bienes, aunque tenga mala fe, con intento de restituir si viniere a tiempo que pueda, como la mujer de usurero, pero si esta tal viese que los multiplicos todos son de bienes robados que multiplican de suyo y tiene otros bienes de que poder bivir estará obligada $\alpha$ mantenerse dellos.

Item se determinó que la dicha mujer del conquistador que tuvo buena fé y la a tenido, no sabiendo ni pensando que los bienes de su marido fuesen robados pueda gozar durante la buena fee de la mitad de lo multiplicado y sustentarse della y hazer como de cosa suya y si durante esta buena fee pasa el tiempo de la prescripción puede in perpetuum ser señora de la mitad del tal multiplico.

Item se determinó que los mercaderes $y$ otras cualesquier personas que vendieron o an vendido a los conquistadores o a otras personas cuyos bienes están todos obligados a restitución, si las tales cosas que les vendieron son de las que se consumen con el uso, como ropa, vino y otras cosas de esta calidad, que estarán obligados los tales mercaderes o vendedores $\alpha$ restituir todo lo que llevaron por sus mercadurias, excepto lo que fué necesario para la sustentación de la vida del conquistador, pero si aquellas mercadurias no las consumió ni quedó el que mercó más ynábil para restituir que antes que comprase, no estará obligado el mercader a restitución, aunque sean cosas que con el uso se consumen.

Iten se determinó que quando los tales mercaderes venden $\alpha$ los dichos conquistadores $o$ a otros cuyos bienes están obligados a restitución cosas que con el uso no se consumen, como joyas, perlas, heredades, mulas, cavallos, que no estón obligados a restitución, pues que los conquistadores con la tal compra quedaron tan ábiles como antes para restituir.

Iten se determinó que los mercaderes que en tiempo de guerra injusta recibieron armas para la tal guerra, a sabiendas o en duda si era justa o no, estarán obligados a restituir in solidum como los que hizieron el daño con ellas, pero si los tales mercaderes tuvieron ygnorancịa bastante de la tal guerra $y$ entendieron con su buena fee que no eran para guerra injusta, no están obligados a restitución.

Iten se determinó que qualquier criado de persona cuyos bienes todos están obligados a restitución no puede llevar ningún salario del tal amo y si lo llevare estará obligado a restitución y lo mesmo se dize del calpisque ${ }^{11}$ - mayordomo del encomendero que no fué conquistador, que no cumple con nada de lo que a sus yndios es obligado, asi en doctrina como en policía, no teniendo el amo otros bienes ningunos sino el tributo que injustamente llebó a los indios, pero si el tal encomendero no conquistador, aunque no cumple con los indios, como dicho es, tiene otras haziendas o granjerías o habiendas de donde lo pueda pagar, podrá lícitamente llevar su salario.

Iten se determinó que si los tales calpisques o mayordomos entendiesen en solicitar a los caciques o indios que diesen a su amo más de lo justo, que de todo aquello que por su solicitud llevaron más sus amos serán ellos

(11) Calpisque o mejor Calpixque es palabra mexicana que significa cuidador de la casa, do calli: casa y pixqui: guardián. También se traduce por mayordomo. En el Perú se aplico en la costa a los indios fiscales de doctrina o catequistas. En la sierra se les dió el nombre de Sayapayac, esto es el mayordomo ó administrador de otro. También, como dico Calancha, se les denominó Viczaraicu, ó persona que por la comida sirve a otro, de vicza, vientre $y$ raycu, por amor de ó por causa de. 
obligados a restituirlo a los indios y otro qualquier agravio que les hagan, precio estimable, si los amos no lo restituyeran.

Iten se determinó que los que tienen indios en encomienda, si tienen y an tenido doctrina suficiente y cuidado de la policía y buen enseñamiento de sus indios podrán llevar un honesto tributo para su sustentación, considerada la calidad de la persona y el provecho que en la tierra haze.

Iten se determinó y declaró que la cantidad de dicho tributo no se a de medir por las tasas o retasas que están puestas sino por la conciencia del buen varón y temeroso de Dios, porque si los indios son tan pobres y necesitados que no pueden dar mill que dize la retasa no los podrán llevar con buena conciencia sino aquello que buencrmente pudieren dar, quedándoles tiempo para entender en sus haziendas y granjerías y sustentar sus casas e mujer $y$ hijos, no haziéndolos venir en necesidad por el tributo que no pueden dor.

Iten se determinó que si los indios son ricos y pueden holgadamente dor lo que manda la tasa o retasa sin ser agraviados en nada, como dicho es, que lo podrán llevar y no mas, cumpliendo, como está dicho, con doctrina y policia con los dichos indios.

Iten se determinó y declaró que por suficiente dotrina se entiende que ningún niño se muera sin bautismo ni ningún adulto baptizado sin confisión y que todos sepan las cosas necescrias a la fee, como el credo, paternoster. ave maría y los diez mandamientos de la ley y los mandamientos de la yglesia $y$ se les platique y dé $\alpha$ entender lo susodicho en la mejor manera que ser pudiere, según su capacidad.

Item se determinó que el que faltó de tener doctrina, todo el tiempo que no la tuvo por ningún ministro ni por su persona, lo que avia de dar al padre sacerdote o sacerdotes necesarios para el enseñamiento bastante de los indios a de restituir $\alpha$ los indios, según el tiempo que no la tuvo ni enseñó y si haziendo sus diligencias no pudo hallar el clérigo necesario para la doctrina ni él la enseñó, está obligado a restituir a los indios lo que avia de dar a los clérigos o frayles, pero podrá llevar de lo residuo del tributo alguna parte muy moderada para su onesta sustentación y de su casa' y no más y esto por razón del cuidado de la policía de los indios y por hazer cuerpo en esta república cristiana que está acó para sustentar la tierra en paz y ell justicia $\mathrm{y}$ para que los indios tamen las costumbres cristianas de seguir $\mathrm{y}$ frecuentar la yglesia y aprovecharse del fruto de los sacramentos.

Item se determinó y declaró que los encomenderos están obligados a saber $y$ entender si los yndios que tienen en encomienda pueden holgadamente $Y$ sin perjuizio de su sustentación y casas cumplir con el tributo señalado por la tasa o retasa y para saber no se han de fiar de sus criados y calpisques si no en persona, sin molestar ni agraviar a los indios han de ver $y$ conoscer su posibilidad y conforme a ella podrán moderar el tributo por las leyes de la conciencia, como dicho es.

Item se determinó que estén obligados los encomenderos a bivir con cuidado de saber si los frailes o clérigos que tienen en sus yndios para ia doctrina cumplen lo que son obligados así en hazer juntar los indios para la doctrina como en la administración de los sacramentos y si tienen cuenta con los pobres y enfermos y si les dan buen exemplo en todo lo que tienen obligación, como ministros de jesucristo y si en estas cosas o en cualquier dellas faltaren o fueren negligentes den aviso a su obispo o perlado a quien están sujetos.

Item se declaró que los dichos encomenderos han de poner mucha diligencia en saber cómo los caciques y prinçipales tratan a los yndios comu- 
nes y pobres, sabiendo si los roban con achaque del tributo, haziendo trabajar a los yndios y a las yndias para que le den más de lo justo, por te. ner ellos que gastar en botijas de vino de castilla como se sabe que muchos lo hazen $y$ en todo esto han de procurar el remedio o por via de justicia o por el mejor modo que pudieren, como ello se remedie y sientan los pobres yndios que el encomendero está puesto más para que mire por ellos que no para llevar el tributo.

Item se determinó que si algún conquistador o otro oviese tomado algunas ovejas o otra cosa de las que multiplican y las oviese luego consumido que estará obligado a restituir las ovejas o bienes del multiplico, conforme al valor que tenían quando las tomó o consumió, como si uviera que. mado mieses estando en berza, que está obligado a restituir lo que valía al tiempo que las quemó, pero si no uviese consumido las tales ovejas o bienes de multiplico estará obligado a restituir todos los partos y pospartos y multiplicos, deductis expensis justis ${ }^{12}$.

Item se determinó que si alguno oviere rescibido alguna cosa de pre. cio, que no sea parva, de algún conquistador o de otros cuyos bienes están obligados $\alpha$ restitución que está obligado el que rescibió a bolver la cosa o su valor a la persona de quien lo rescibió, si entiende que lo restituirá $Y$ si no piensa que lo hará que lá buelva a los indios, avisaṇdo al que se lo dió cómo hizo la tal restitución y esto se a de hazer quando se sabe quáles fueron los yndios o personas de quien se tomó o sus herederos, si no estuvieren tan lejos que sean más las expensas quel principal y quando no se pudiere saber a quien se han de restituir se emplearán en beneficio del pueblo o provincia damnificada. Si, como dicho es, no está tan lejos que sean las expensas más que el principal y este descargo se a de hazer con parescer del Obispo y en su ausencia del confesor, al qual se le encarga que no lo entendiendo bien se ynforme de personas que lo entiendan.

Las personas que con el Iltmo. y Rvdo. Sr. Arzobispo de los Reyes. se hallaron pora definir y determinar todo lo susodicho fueron los siguientes:

Los Muy Rrdos. provinciales de Sancto Domingo, San Francisco: Fray Gaspar de Carvajal, Fray Francisco de Morales.

El P. Prior de sancto domingo de Lima, Fray tomás de argumedo, presentado en santa teologia.

el prior de señor sant Agustin de Lima, fray andrés de Ortega.

fray ambrosio guerra, presentado en santa teologia.

tray gerónimo de Villacarrillo, tray pedro de cepeda.

el licenciado Don Bartolomé Martínez, arcediano en esta santa yglesia. Merced.

el padre fray miguel de orenes, vicario provincial de nra. sra. de la

el doctor Domingo Marquina ${ }^{13}$.

Acabóse $a$ onze de marzo de mill y quinientos y sesenta años y los dichos con su Señoría Revma. lo firmaron de sus nombres.

Después que vino el P. Hernández y los demás PP. de España se empezaron a tratar estas materias y a conferir dellas para instruction de los que venían y de los que acá estavan para que todos conviniésemos en la

(12) Esto es: deducidos los gastos justos.

(13) Borroso en el original, pero creemos fundadamente que se trata del Chantre D. Domingo Marquina. 
doctrina que se obiere de tener y asi las conferencias de los casos que se tuvieron por muchos dias fué desta materia, poniéndose la pregunta al modo que aquí va y la resolución al pié della.

Pregunta: Suppuesto lo que se usa ya en las Indias que el Rey o los que las goviernan en su lugar encomiendan los indios pregúntase a qué cosas estarán obligados los encomenderos para llevar con buena conciencia los tributos que se les señalan y asi mismo cerca de qué cosas estará obiigado el confesor a examinarlos quando los confiese por razón de la encomienda.

Respondiendo a esta pregunta lo primero presupongo que asi como el Rey puede tener los indios en si y no conviene que los dexe y puede obligarles $\alpha$ que le paguen los tributos justos y el servicio justo por administrarlos y governarlos en justicia y lo demás necessario, de la mesma manera los puede encomendar a otros con la mesma obligación y carga que el Rey tiene y obligar a los indios que les paguen los tributos justos. Esto es lo que el Rey dize en la encomienda que se los encomienda con la obligación y carga que él tiene y les encarga su conciencia para que hagan y cumplan lo que en la encomienda se dize y descarga la suya. Lo segundo se dize que ya que son cristianos están también obligados lo dichos indios a pagar los diezmos de los fructos de la tierra para los que les administran y enseñan en lo espiritual y ya que no paguen diezmos estarán obligados a dar sustentación cóngrua a los dichos ministros ecclesiásticos como agora se haze que del tributo se saca para los ministros. Esto todo es tan notorio que no es necesario provarlo.

Segundo, presupongo para responder a la pregunta que conviene excluir dos extremos que suele aver en esta materia uno de los que usan mucho rigor no creyendo a nadie, condenándolo, todo, otro de los que usan demasiada benignidad, absolviendo a todos y creyéndose de lo que les dizen fácilmente.

His suppositis ${ }^{14}$ respondiendo a la primera parte de la pregunta dezimos: que los encomenderos que tienen indios encomendados por el Rey o por el Governador que govierna en su nombre estarán obligados a tratar bien a los indios y a procurar su conservación y multiplicación y amparo y defensa como se les dize en la encomienda y están obligados a hazer esto por si o por otro que con efecto lo haga y no cumplen con dezir que el governador les prohibe que no entren allá, si se les prohibe por sus deméritos, como el señor de vasallos o de cura de ánimas no cumplirían si por sus deméritos les prohibiesen que no governasen a sus súbditos, porque están obligados a ser tales que puedan cumplir con las obligaciones de su officio - a poner otro que con efecto las cumpla. Esto se prueva, porque el señor de vasallos en España agora los aya comprado, agora se los ayan dado por sus trabaxos y méritos, está obligado $\alpha$ administrar en justicia y amparar y defender sus vasallos para llevar con buena conciencia la renta dellos.

Esto se entiende en caso que el Rey o governador no se encargase desto, poniendo corregidor que hiziese lo que el encomendero estava obligado a hazer quanto $\alpha$ esta parte, porque en tal caso no estará obligado a lo hazer $y$ aunque les prohibiesen habitar entre ellos, aun no quedan descargados de procurar saber si les hazen agravios, para defenderlos por justicia y esto porque comen su sudor $y$ por lo que les dan están obligados $\alpha$ mirar por ellos.

(14) Esto es: Supuesto lo antecedente. 
Item están obligados a ponerles doctrina suficiente conforme al cap. 20 de lo que determinó el Sr. Arzobispo en la junta que hizo y a procurar que sean ynstruidos en la ley natural y buena policía haziendo todo esto como se les dize en la encomienda del Rey o del governador y cesando de los agravios que alli se manda que no les hagan podrían llevar con buena conciencia los tributos que el Rey les señala conforme $\alpha$ la tasa justa, y no lo haziendo no lo lleva con buena conciencia, probatur quia benefficium datur propter officium \& en el fin de Rescriptis in $8^{\circ}{ }^{15}$. Desto se a de ver en todas maneras el cap. en la instruición de lo que a de hazer el visitador que es el tercero y último de los que se an de notificar al encomendero después de hecha la visita en el qual se dize que la causa porque se le dan los indios es porque los instruya y defienda y haga lo demás que en la encomienda se le manda y que no haziéndolo esté obligado a bolver los tributos que les a llevado y que le quiten al tal los indios y los puedan dar a otro con la mesma obligación.

Asi mesmo dezimos que por doctrina suficiente se entiende que ningún niño se muera sin baptismo ni ningún adulto sin confesión y que todos sepan las cosas necesarias a la salvación como los artículos de la fee, el credo, mandamientos de la ley de Dios y de la yglesia y las oraciones, particularmente el pater noster y que se les platique y de a entender lo susodicho según sus facultades, conforme a lo determinado en la dicha junta, capítulo 20 .

Adviértass que se determinó en el Concilio Provincial deste Reyno que una doctrina no pudiese tener a cargo más de hasta 400 indios casados.

Dezimos que aquella se llamará tasa justa no aquella que se tasó al principio, ni tampoco se llamcrá justa tasa por haverse retasado, si los indios no la pueden pagar, sino quei la tasa justa se a de regular por alvedrio de buen varón $y$ temeroso de Dios tenido respecto a que la puedan pagar los indios sin molestia ni vejación y que les quede para poderse sustentar a si y a sus mugeres y hijos conforme a lo que se determinó en el cap. 18.

E los que faltan de hazer estas cosas no haziendo ellos por si lo que a ellos toca y no haziendo que se haga lo demás no llevan con buena consciencia los tributos o a lo menos la mayor parte dellos.

El que falto de tener doctrina de sacerdote que pueda enseñar lo que arriba se a dicho o no pudiendo hallar sacerdote no la a enseñado por si, sabiéndola, o por otro lego que la sepa enseñar, a de restituir, a los indios todo lo que avia de dar al sacerdote o sacerdotes aunque podró llevar lo residuo del tributo conforme al cap. 21 .

Ase de notar que si él o otro légo objere enseñado la doctrina, por no hallar sacerdote, que no a de descontar por esto tanto como avia de dar al sacerdote sino lo que mereceria un lego y lo demás que se avia de dar al sacerdote se a de restituir a los indios.

Los que an llevado más que la tasa o an hecho alguna de las cosas que se les prohibe en ellas o en las encomiendas del Rey más modernas estarón obligodos a restituir lo que an llevado de más y a todos los daños $\mathrm{y}$ menoscabos que a los indios se les obieren hecho, conforme al parescer del prudente $\mathrm{y}$ docto confesor.

(15) Esto es: se prueba porque el beneficio se otorga por el oficio y la cita siguiente debe estar tomada de las Decretales. 
El confesor deve ser muy cauto y provado en hazer que se haga la satisfacción a los indios para que absuelva a los tales encomenderos o haziéndoles hazer una escritura por ante escrivano, por la qual se obliguen $\alpha$ los yndios a quien son a cargo, diziendo que se constituyen por deudores en aquella cantidad de los dichos indios y la pagarán a tal y tal plazo $Y$ si no estubiere líquida la quantia se diga que dará y pagaró a los dichos indios la cantidad que el Sr. Arzobispo o Obispo o el que estubiere en su lugar y el $P$. fulano su confesor señalaren y esta escriptura se a de procurar que se entregue al prelado para que la haga executar y dé noticia della $\alpha$ los indios, porque si queda en poder del confesor y después él se la haze executar será ocasión de que se ofendan y que asi se hagan los sacramentos odiosos o que digan que les revelan las confesiones o cosas semejantes.

Quanto a la segunda parte de la pregunta se responde que el confesor ultra de lo que a de preguntar por razón de ser cristiano y casado, si lo es. y padre de familia, le preguntará por razón de ser encomendero si a hecho alguna de aquellas cosas que en las encomiendas se le prohiben que no haga y también le podrá preguntar las preguntas que el Obispo de los Charcas scrivió y asimismo si a guardado el juramento que hizo quando le encomendaron los dichos indios. Para saber hazer estas preguntas a de tener hecho un interrogatorio dellas, el qual se a de sacar de la encomienda y del juramento que él hizo quando se los encomendaron y de aquellas preguntas que hizo el obispo de los Charcas que hera varon muy docto y siervo de Dios y de mucha experiencia. Con esto parece que queda respondido por agora a la pregunta hasta que Dios ordene otro mejor orden de govierno para con estos indios ${ }^{16}$.

Arch. Rom. Soc. Jesu. Perú.

\section{IV}

Como habrá visto el lector en estos avisos se halla condensada la doctrina ética por la cual se regían los confesores de encomenderos en general, pero los de la Compañía no contentos con lo que se había resuelto en la Junta convocada por el Arzobispo Loayza y a fin de evitar cualquiera mala inteligencia redactaron ua serie de preguntas, basadas en la Cédula de la encomienda, a fin de poner en claro si se había faltado ó no a la obligación y, juntamente con esto, hicieron suyas las 19 que redactó el Obispo de Charcas, Fray Domingo de Santo Tomás, celoso defensor de los indios y buen conocedor de las cosas del Perú. Aun esto no bastó y con motivo de las disposiciones del Virrey Toledo, sea sobre las encomiendas, sea sobre la tasa que debían pagar los indios, se adoptó el procedimiento que el P. Bartolomé Hernández propuso en una consulta habida en el Colegio de Lima. La ley amparaba, sin duda alguna, el derecho del indígena, pero en la práctica resultaba más eficaz la acción sacerdotal que influía en las conciencias. La ley podía burlarse y el agravio quedaba muchas veces sin sanción, pero ante el tribunal de la penitencia el reo quedaba convicto y confeso y obligado a reparar los daños. Esta influencia social no era desdeñable, ni mucho menos, en un siglo de honda fe religiosa.

El primer parecer que damos a luz en esta serie es obra del célebre P. Diego de Torres Bollo y se refiere a la perpetuidad de las encomiendas, asunto largamente debatido, desde el punto en que se establecieron en Amé.

(16) Arch. Rom. Soc. Jesu. Perú. Historia. 
rica. Si bien las Nuevas Leyes (1542) habían zanjado la cuestión, suprimiendo esa especie de feudo, en la práctica la encomienda perseveró $y$, en 1558. al ser enviado al Perú el Conde de Nieva, una de las tareas que se le encomendaron a él y a los Comisarios fué la de examinar si se extinguirían las encomiendas en las dos o tres vidas, para que fueron concedidas o se las había de otorgar a perpetuidad. Muchos, entonces $y$ después, fueron partidarios de esto último, con algunas limitaciones y entre ellos el P. Torres. Este había sido designado Procurador de la Provincia del Perú en la Congregación Provincial de 1600 y, al siguiente año, se embarcó para Es. paña. Ya en la Corte fué consultado sobre este espinoso asunto, todavía no enteramente resuelto y debió enviar su parecer al Duque de Lerma, favo. rito de Felipe III. EI P. Torres conocía bien el Perú, pues había desempeñado el cargo de Superior de las casas de Juli y de Potosí algunos años y también se había hallado en Quito cuando la famosa rebelión de las Alcabalas. Tanto este suceso como la situación de los indios, cuya disminución era notoria, le movieron $\alpha$ dar su parecer en favor de la perpetuidad, pero, como se echa de ver, las razones en que se funda son todas de órden social y apuntando al bienestar de los naturales y pacificación de la tierra.

Dice el P. Torres: "Ha mós de 70 años que se trata si converná que se perpetúen los repartimientos de indios que ay en todas las Indias en las personas que los tienen encomendados por dos o tres vidas y también las que están en la corona real, si es más conveniente que asi como vayan vacando se pongan en la corona y la órden y asiento que en esto se podía dar y sobre ello se an tomado en este tiempo diversos pareceres de muchas y muy graves personas y haviéndose juzgado que convenía hazer la perpetuidad de toda la tierra del Perú, como por su parte se havia pedido y que se podría sacar gran suma de hazienda para las necesidades y guerras que se ofrecían a S.M. Y que importava para la conserbación, acrescentamiento y seguridad de aquellas provincias, se embiaron Comisarios el año de 60 al Perú, con comisión y facultad muy cumplida para ponerla en execución $y$, queriendo usar de sus comisiones, hallaron tantas dificultades $y$ contradiccionss y tanta incertinidad en los presupuestos que se hizieron para esta resolución que, haviendo avisado a S.M. (que aya gloria) de lo que pasava y les parescia, tuvo por bien de mandarles que se volviesen, como lo hicieron, $\sin$ executar cosa alguna" 17.

Esta es en suma la historia de la encomienda en el Perú hasta la fecha indicada por el P. Torres, el cual añade unas líneas mós abajo que hacia doce años no se había vuelto a tratar el asunto hasta aquel entonces, cuando las cosas de Indias habían sufrido alguna mudanza, no obstante lo cual, el Virrey D. Luis de Velasco y otras personas celosas de la conservación del Reino se inciinaban hacia la perpetuidad ${ }^{18}$.

No puede negarse que era muy aceptable la tésis defendida por el $P$. Torres, tal y como él la planteaba y, posiblemente, mejor que la contraria, pero la dificultad estribaba en que no se habían de cumplir todas las condiciones exigidas a los encomenderos. Por otra parte, no estaba en lo jus-

117) El parecer del P. Torres está tomado de un vol. en fol, encuadernado en pasta, procedente del Colegio Mayor de S. Bartolomé de Cuenca, en Salamanca $\mathrm{Y}$ hoy en la Biblioteca del Real Palacio. En el mismo se registran diversos pareceres sobre la misma materia: uno del Marqués de Cañete, otro del Lic. Francisco de Sandoval, id. de Juan de Ibarra y otros.

(18) V. Vargas Ugarte. Historia del Perú. Virreinato. Siglo XVI. Buenos Aires, 1949, p. 123. 
to el P. Torres al pedir que se concediese jurisdicción sobre sus indios al encomendero, por que esto lo rechazaban aun los partidarios de la perpetuidad $y$, ciertamente, lo constituía en una especie de señor de horca $y$ cuchillo, dejando al indio indefenso en sus manos. Tampoco nos parece muy acertada su opinión en cuanto a suprimir los Corregidores, pues si bien es verdad que estos abusaron de su oficio, la institución en sí era provechosa y benéfica para los indios. Los encomenderos, aun en los primeros tiempos, cuando se hacían cuenta de que habian de gozar la encomienda a perpetuidad, no fueron mejores. En cambio, atinadamente advierte que las encomiendas se han de dar tan sólo a los beneméritos, esto es, a los conquistadores $0 \alpha$ sus descendientes en línea recta $y$ asimismo el que se evite el que pase a América gente vagabunda $y$ que los que vinieren sean obligados a ejercer los oficios que ejercían en España y no quieran pretender acomodos y vivir a costa de los indios.

Es revelador lo que dice acerca de los mestizos. Sugiere que no se les permita vivir entre indios $y$ mucho menos casarse con indias $y$ los considera gente perjudicial y pronta siempre a alborotarse y armar sediciones. Común fué en aquellos tiempos tener en poco a los mestizos y recelarse de ellos. La sumisión del indio contrastaba con la rebeldía del mestizo y no podía ser del agrado de los españoles, pero en el fondo latía ya la oposición entre lo nativo y lo extranjero. Lo peruano era lo mestizo y la voz de la tierra y de la sangre tenía que dejarse sentir cada vez con más fuerza.

Cronológicamente el parecer del $\mathrm{P}$. Torres debía venir después, pero el problema de que se ocupa era uno de los más antiguos en Ámérica y en este sentido le corresponde la primacia. Fuera del mérito encerrado en las razones que alega, tiene además el de documento histórico por el cuadro que nos traza de la situación de las clases sociales del Perú de fines del S. XVI.

El segundo parecer que cquí se inserta más que un alegato jurídico es una relación fehaciente y descarnada de amplificaciones retóricas sobre la miserable suerte de los mitayos de Potosí. Mucho se ha escrito sobre la materia pero creemos que pocas páginas más objetivas $Y$ terribles que las debidas a la pluma del P. Antonio de Ayans. Este era oriundo de Navarra y de noble prosapia. Su hermano, D. Jerónimo de Ayans, era señor de la Casa de Gandulay, entroncada con la rama real de Navarra y deudo de San Francisco Javier. En su mocedad había pasado a Salamanca con ánimo de graduarse en derecho, pero allí la voz de Dios le llamó a la Compañía e ingresó en ella. Era todavía estudiante, cuando se sintió movido a pedir le enviasen a las Indias $y$, aceptado su ofrecimiento, se embarcó en cornpañía del P. Andrés López, Procurador de la Provincia del Perú. Llegó a Lima en el año 1585 y en esta ciudad terminó sus estudios teológicos y se ordenó de sacerdote. Enviado al Colegio de La Paz, fué señalado por compañero del P. Miguel de Urrea, que había venido con él desde España quien se preparaba a entrar a los Chunchos de Apolobamba, en cuyas manos vino a morir mártir. Habiendo enfermado gravemente muy a los principios de esta misión, hubo de volver al Colegio de La Paz y, desde entonces ejerció el penoso oficio de misionero de indios, tanto en la comarca da 
Chucuito como en Potosí, hasta que su falta de salud le obligó a volver al Colegio, donde falleció el 30 de Mayo de 1598, a los 45 años de edad ${ }^{19}$.

Su vida en las provincias de donde salían los indios de mita para el rico cerro y la experiencia adquirida en el mismo Potosí le convierten en un testigo de mayor excepción. Su corazón de apóstol se conmovió ante el espectáculo que vieron sus ojos y tomó la pluma para defender a los indios de los maltratos que se les inferían y dar a conocer el intolerable yugo que pesaba sobre el indígena y le abatió aun mós de lo que estaba después de la conquista. El cuadro es pavoroso y nada se podrá aducir para justificarlo. El P. Ayans lo traza con mano segura, como que está cierto de lo que dice $\mathrm{y}$, al mismo tiempo, sin pasión. No son sus razones las que nos convencen sino los hechos que cita. Mayor nervio de argumentación hallaremos en el parecer del P. Pedro de Oñate, cuando éste nos hable de la mita de Huancavelica, pero la realidad tal cual nos la presenta el P. Ayans resulta más convincente. El autor no llegó a ver impreso su trabajo, que, $\alpha$ su muerte, se halló entre sus papeles y alguno debió, remitirlo a España, tal vez al Consejo de Indias, donde se perdió entre el acervo de papeles que afluían a la Corte y quedaban luego amontonados en los anaqueles de una secretaría. Bien vale la pena de que salga a luz, como un testimonio de lo que sentía y hacía este insigne defensor de los indios.

De fines del $\mathbf{S}$. XVI $\in \mathrm{S}$ el parecer que dieron al Virrey D. Luis de Velasco los PP. del Colegio de Lima sobre si era lícito o no el repartir indios a las minas nuevamente descubiertas. Fntre los firmantes figura el célebre P. Juan Pérez Menacho, que tan gran fama de teólogo y hombre docto dejó entre sus contemporáneos, pero del cual apenas nos han quedado algunas disertaciones jurídico-canónicas y sus comentarios a la Suma de Sto. Tomás, casi todos manuscritos ${ }^{20}$. Los Jesuitas de Lima están acordes que no es lícito ni conveniente gravar cun más a los indios de lo que están, enviándolos a las minas que se descubrieren. No van más allá, ciñéndose a la pregunta que se les hace, pero queda manifiesto su sentir sobre las mitas forzadas para minas.

Asunto muy debatido y que arrancaba casi desde el descubrimiento era el relativo al servicio personal. Este, tal como se había implantado, venía a ser una esclavitud disimulada. Contra él habían clamado los frailes doctrineros y el Obispo de Chiapas ${ }^{21}$. En una $u$ otra forma continuó, si bien

(19) Jacinto Barrasa. Historia de la Compañía en el Perú. Ms. Tom. 2. Catálogo de Varones Ilustres en santidad que murieron en el Colegio de Chuquiabo. No 6. Arch. Col. Lima.

(20) En la Biblioteca Nacional de Lima, Ms. 0003, se guardaba un papel titulado: Respuestas de los PP. Felipe Claver, Pedro del Castillo y Juan Pérez Menacho sobre las dudas que se presentaron sobre las Ordenanzas de Gonzalo de Abrego (Abreu), para el Tucumán. Diéronse en 1601 y lamentablemente perecieron en el incendio del edificio.

(21) Como es sabido Fr. Bartolomé de las Casas que contradijo la esclavitud de los indios no se opuso antes favoreció la traida de negros esclavos. La introducción de estos se remonta casi a los primeros años del Descubrimiento. (Bol. Acad. de la Hist. de Madrid. Vol. 28, p. 507. Orígenes de la Esclavitud en América). Al Perú llegaron también casi a raiz de la conquista. Francisco de Barrionuevo, escribiendo a S.M. el 23 de Diciembre de 1533 le dice desde Panamá, que algunos navíos eran idos al Perú con toda la más gente que había y algunos negros. Alguno llevó consigo los 24 que tenía. Cuan grande era el número de indios sujetos al servicio de los españoles se podró colegir del hecho siguiente. Hacia 1532 Panamá sólo contaba con $32 \circ 33$ vecinos españoles $Y \cdot 10$ indios de servicio llegaban a 500 . 
un tanto mitigado, hasta que en el año de 1601 se dió la fơmosa cédula, aboliéndolo. Al recibir el real despacho D. Luis de Velasco, a la sazón Virrey del Perú, se halló tan embarazado con los inconvenientes que se le presentaron que el $1^{\circ}$ de Mayo de 1603 escribía al Rey, exponiéndole con prolijidad las causas que le impedían ponerlo en ejecución. Consultó a la Audiencia, reunió a los teólogos y juristas que en lima residían y los pareceres fueron encontrados. Fray Miguel de Agia, franciscano, dió a luz su famoso: "Tratado que contiene tres pareceres graves en Derecho", impreso en Lima en 1604. Agia defiende el servicio personal y juzga que su supresión no podría hacerse sin grave daño de toda la república. Cree que el Rey puede compeler a los indios a prestar estos servicios, incluyendo el trabajo de las minas y sólo en el tercer parecer se retracta por lo que hace a las minas de Huancavelica, después de haberlas visitado.

Como él pensaron otros muchos, pero no faltaron quienes rebatieron sus razones. Uno de los más autorizados fué el P. Francisco Coello que en Lima, antes de entrar en la Compañía, había sido Alcalde de Corte y Ásesor de D. García Hurtado de Mendoza. No conocemos el trabajo del P. Coello, pero tanto el P. Diego de Ãvendaño como Solórzano Pereira lo citan con elogio y lo tuvieron en sus manos. A falta del mismo se podrá ver el antes citado de los Padres del Colegio de Lima, que tiene unos años de adelanto $\alpha$ estos sucesos $Y$, sobre todo, el que dió al mismo D. Luis de Velasco el P. Alonro Meszia Venegas, en 1603 y. más tarde, a D. Rodrigo de Aguiar y Acuña del Consejo de S.M. en Madrid, en 1607. Si bien Lorente insertó este parecer en el tomo II de sus: "Relaciones de los Virreyes y Audiencias que han gobernado el Perú", apareció tan plagado de errores que bien vale la pena reproducirlo.

El P. Messia no es de opinión que se suprima el servicio personal por los inconvenientes que la misma cédula tiene previstos $y$, respondiendo $\alpha$ la cuestión práctica, de si debe o no ejecutarla el Virrey, asienta que éste, en virtud de la facultad que se le otorga en otra cédula, puede suspender su ejecución y conviene que así lo haga. Estudia los medios que en la misma céaula se proponen para suplir la falta del servicio forzado de los indios y halia que ninguno satisface, antes bien están llenos de inconvenientes. Pasa luego a examinar las ventajas o desventajas del servicio personal de indios en las sementeras $y$ en las minas y concluye que para lo primero son indispensables $y$ el servicio cede en provecho de los mismos indios, si bien se hace necesario corregir algunos abusos. En las minas, este servicio está ya entablado y tolerodo. Suprimirlo traería consigo daños irreparables y así sólo discute si convendrá utilizar los indios en aquellas minas que son de poco truto. No desconoce, sinembargo, los agravios que se hacen a los que vin a Potosí e insinúa el remedio.

Entre ellos, el de poblar el distrito de Potosí con el número de indios que bastasen para el entero de la mita, cada tres años, es el que le parece mejor. Ya en tiempos de Toledo se había tratado de esto, pero no se conoció practicable, porque, dada la esterilidad de la comarca, si se hacía difícil proveer a la ciudad, en tiempos normales, el problema se agravaría si se multiplicaban sus habitantes y los de sus cercanías. Messía se propone las objeciones del caso y trata de hallarles solución. Creemos que en esta parte flaquea su discurso. El, como otros muchos hombres de su tiempo, se habían persuadido que los indios de su voluntad no habían de ir a las minas $y$ que el laboreo de estas era indispensable para la prosperidad común. Partiendo de estas dos premisas, sacaban sus conclusiones. Reconocían que se hacía fuerza al indígena y se violaba su derecho de hombre libre, pero 
apelaban a la urgente necesidad del Estado y también a la voluntad del Soberano. Este sacrificio del individuo que hoy nadie admitiría y que aun entonces muchos se negaban a aceptar; encontró apoyo, sinembargo, entre algunos teólogos y juristas y uno de ellos fué el P. Messia, con las reservas necesarias, pues al final no puede menos de decir: "Concluyo que si la Real Cédula de S.M. se pudiera ejecutar sería el mayor remedio y más propia encuadernación que se podrá dar a este Reino".

\section{VI}

En 1610 el Marqués de Montesclaros escribió al Lic. Maldonado de Torres, Presidente de la Audiencia de Charcas, a fin de que convocase en Potosí a una Junta, asi de oficiales reales y prelados de las Religiones como de azogueros y mineros, a fin de que estudiasen el asunto de la mita. El 8 de Marzo de dicho año se celebró la junta, a la cual se halló presente D. Francisco de Alfaro, nombrado Visitador de las Provincias del Tucumán y Río de La Plata. No se tomó entonces resolución alguna, pero se convino en que unos y otros, de común acuerdo, diesen su parecer y luego en otra junta se examinasen y se enviasen al Virrey los que se creyeran más convenientes. No sabemos cuáles fuesen los pareceres remitidos a Montescla. ros, pero el P. Diego Alvarez de Paz, Rector del Colegio de Lima, puso en manos del Virrey el que ahora trascribimos. Los Padres de Potosí comien. zan por referir los agravios que se hacen a los indios con el servicio de la mita y claramente la tienen por injusta. Juzgan que sería conveniente repoblar las provincias de donde proceden los mitayos, a fin de aliviarles la carga y obtener que sólo les quepa la mita cada 7 años y sólo trabajen 4 meses, el año que les corresponda. Consideran que sería vano intento $\mathrm{y}$ muy perjudicial el tratar de poblar de indios de mita la comarca de Potosí, pero en cambio juzgan hacedero que se favorezca el avecindamiento de indios voluntarios que, unidos a los que ya existen en Potosí, podrían dedicarse a la labor de las minas por su justo salario y relevándolos de todas las demás cargas que pesan sobre ellos y les hacen intolerable la vida. Este parecer, al cual se adhirieron no pocos mineros y azogueros, es, sin duda, uno de los mejores que poseemos sobre un asunto tan espinoso como el de la mita.

Los que siguen versan sobre el servicio personal, entablado en las Provincias del Tucumán y Río de La Plata y al cual vino a poner remedio D. Francisco de Alforo con sus Ordenanzas. El primero se debe al P. Diego de Torres, a quien ya nos hemos referido, Provincial entonces de aquella nueva Provincia y está tomado de la Carta Anual que en 1612 remitió, desde Córdoba, al P. General Claudio Aquaviva ${ }^{22}$. El sequndo lo dieron los teólogos de nuestro Colegio de Lima y lo hicieron suyo los PP. del Tucumón. Como los vecinos de estas regiones quedaron lastimados en sus intereses, $\alpha$ l publicarse las Ordenanzas de Alfaro, muchos de ellos se resistían a obedecerlas y de allí el escrúpulo de los Jesuitas sobre si podían o no absolverlos. Los PP. de Lima declaran abierta y llanamente que las dichas Ordenanzas deben guardarse bajo pena de pecado grave $\mathrm{y}$, por tanto, los que a sabiendas las quebrantan no pueden ser absueltos si no reparan los daños

(22) V. Documentos para la Historia Argentina. Tomo XIX. Iglesia. Cartas Anuas de la Provincia del Paraguay. (Buenos Aires, 1927). Publicación del Instituto de Invest. Hilstór. de la Fac. de Filos. y Letras. p. 484 y s. 
y agravios inferidos. Uno $\mathrm{y}$ otro parecer pone una vez más en evidencia la independencia y rectitud de criterio que usó la Compañia ante los abusos de los vecinos y pobladores, aun con riesgo de malquistarse con ellos y perder su amistad y protección. Pero sobre todo esto estaba la verdad y el derecho.

El P. Pedro de Oñate fué uno de los hombres que más ilustraron la Provincia Peruana. Nacido en Valladolid, vino al Perú en el año 1592, siendo todavía estudiante. Aqquí completó su formación y en 1604 lo hallamos de Rector del Noviciado. En 1615, el General de la Compañía lo nombró Provincial del Paraguay, sucediendo en este cargo al fundador de esta Provincia, el P. Diego de Torres. Bollo. No le seguiremos en su larga carrera. Vuelto al Perú, tuvo a su cargo, en atención a sus vastos conocimientos de Teología Moral, la resolución de los casos de conciencia que cada mes se discuten en nuestras casas, según el Instituto. En un vol. en $4^{9} \mathrm{~ms}$. que hemos visto en la Biblioteca del Seminario de Ayacucho se conserva buena parte de ellos, pero bastarían a acreditarlo de buen moralista y canonista los tres tomos que sobre la materia de Contractibus dió a la estampa en Roma en 1646-1647.

El parecer aquí inserto se remonta al año 1629, gobernando el Virreynato el Conde de Chinchón. El mismo P. Oñate nos explica el porqué del mismo. Estaban señalados 2,000 indios de mita a Huancavelica, pero como las provincias de donde se remitían se hallaban asoladas, se trató por parte del Virrey de examinar si sería lícito repartir nuevos indios de otras provincias hasta completar ese número. Se consultó a los de la Compañía y se discutió el caso entre ellos. El encargado de dar la solución a las preguntas que se hicieron fué el $P$. Oñate $y$ lo hizo con una libertad de pensamiento, una solidez de juicio $y$ un caudal de doctrina que dejan admirados. Comienza por plantear la cuestión que en el fondo se debatía y que no era materia de la consulta pero la sobreentendía, esto es: si era lícito ó no compeler a los indios a trabajar en Huancavelica y concluye que esta mita es contra el derecho natural. Más adelante propone algunos medios que podrían sustituir a la mita para la saca del azogue y en un artículo refuta la aserción, bastante esparcida por los patrocinadores de la mita, que era necesario para el bien de la Iglesia y la conservación de España y de las Indias el azogue de Huancavelica. Con lo expuesto había bastante para responder a las preguntas que se habían formulado.

El P. Oñate, acomodándose al uso de los escolósticos, comienza por establecer el estado de la cuestión y el sentido que se ha de dar a ella, luego cita las razones que en favor de la licitud de la mita se pueden aducir y pasa a probar cómo es contra derecho e injusta. Comienza por asentar los principios que en asunto de tributos se han de adoptar y lo hace con sin igual maestría. En esta parte creemos que el escrito del P. Oñate tiene plena actualidad, porque sus razones son tan valederas hoy como entonces, sea cual fuere el sistema de gobierno de un Estado. Después de ello, enumera la injusticia que se hace a los indios imponiéndoles tan pesada carga y con sobra de razones prueba cómo es a todas luces ilícita.

Solían los defensores de este servicio personal como he dicho, abroquelarse en dos argumentos que no dejaban de hacer impresión en los hombres de entonces. Era el uno, como dice el P. Oñate, que las minas de Huancavelica eran necesarias para que no se destruyese la monarquía española y para la conservación de la fé católica e Iglesia de Dios, supuesto que de otra manera disminuirían las rentas reales y no podrían sostenerse las guerras contra los herejes en Flandes y Alemania. Pero dejemos que el mismo Padre responda: "En cuanto a hazer dependiente la Iglesia de Dios de 
estas minas de Huancarvelica, bien se ve que, por una parte, es cosa poco pía, antes bien del todo impía, pues, así como Dios no necesita de nuestras mentiras (Job. 13.7) tampoco de nuestros agravios y de tan terribles opresianes para conservarse y defenderse de los herejes, pues las puertas del Infierno no prevalecerán contra (la Iglesia). ¿Cuántos años estuvo la Iglesia de Dios más florida que ahora sin Guancavelica? ¿Cuánto mejor medio es para conservar la Iglesia de Dios quitar agravios, opresiones y tan enormes tributos que echarlos sobre las vidas de los indios forzados y sobre las conciencias de los que los fuerzan? ¿Es posible que no tiene Dios en los infinitos tesoros de su Omnipotencia y Eterna Sabiduría otro medio para conservar su Iglesia y defenderla de los herejes sino el azogue de Guancavelica y que no está fija en más sólido e inexpugnable fundamento la promesa y profecía de Cristo: las puertas del Infierno no prevalecerán contra Ella?... Casi la misma es la respuesta a lo de la precisa necesidad de los Reinos de España. Lo primero, negando tal necesidad, pues como se conservó España tantos siglos sin Guancavelica se pudiera conservar ahora. Antes bien, muchos niegan ser verdadero y sólido bien de los reinos de España la mucha plata que saca, porque dicen que la mucha prosperidad y abundancia ha traido consigo el demasiado regalo, superfluidad en gastos y ociosidad, juegos y pasatiempos y con ella se han afeminado los ánimos de los españoles, antes más fuertes y duros para cualquier honesto trabajos y que de aquí ha nacido la corrupción de nuestras costumbres... y que la plata ha empobrecido a España y enriquecido a las naciones extranjeras, porque no ha sido España sino un canal de su plata... ${ }^{23}$ y ha sido causa del inestimable empeño que tiene de tantos millones que la tienen destruída y imposibilitada de remedio".

A lo dicho añade que las rentas reales alcanzan a 22 millones $y$ de estos sólo millón y medio vá del Perú, de modo que no hay fundamento para decir que el estado español dependa de dicho millón y medio y esta cantidad del azogue de Guancavelica. Pero aun dado que asi fuera, ya ha probado que las cargas y tributos se han de repartir conforme $\alpha$ las necesidades de las provincias y reinos que componen la nación y las de unas no han de pesar sobre otras $y$ mucho menos la de todo el cuerpo social sobre una sola de ellas. Antes, tratando este punto había dicho sin rebozo y con franqueza verdaderamente castellana: "Si el Rey tiene necesidad de tanto tesoro para defender sus reinos a los ajenos y para la fe católica y destruir a los herejes, ¿por qué no se distribuye la contribución por todos igualmente, de manera que, como dicen todos los autores, a los más ricos les quepa más y a los más pobres menos, sino tan al revés que a los españoles ricos no cabe nada y a los pobres muy poco y a los indios ordinarios mucho más $Y$ a los indios de las minas que revienten y a los de Guancavelica qué mue-

(23) Ya Saavedra Fajardo (Empresas Políticas. Empresa 69), había dicho que España se había empobrecido desde el descubrimiento, pues había abandonado el fomento de la riqueza interna por irla a buscar afuera. Somoza y Quiroga explicaba la salida del dinero de España por el símil de dos pozos, situados el uno al lado del otro y de distinto nivel. EI agua por fuerza pasaba al de nivel más bajo. dejando al otro exnausto. Macanaz (Semanario Erudito. Tom. V. p. 234), llegó a dudar si hubo verdadera ventaja para España con la conquista de América. Finalmente, creo que un hacendista como Canga Arguelles. fué el que dijo que España era el paladar pero el resto de Europa vino a ser el estómago, adonde afluyeron las caudales de Indias. 
ran mala muerte?". Pocas veces se habrá hablado con tanta entereza Y claridad.

\section{VII}

El papel que se sigue no es propiamente de un autor de la Compañía, si bien es verdad que en cierto sentido se puede atribuir a los jesuitas, tanto por haberlo hecho suyo el Provincial del Perú y los Padres más graves del Colegio de Lima, como consta de la carta que remitieron al Conde de Lemos, como por haber sido ellos quienes, como diremos después, animaron al Conde a escribirlo y le sugirieron la materia.

D. Pedro Fernández de Castro, Conde de Lemos sobresale en todo sentido entre los gobernantes del Perú. Ciñéndonos a la materia de que trata su carta al Rey, ninguno habló más claramente que él sobre la mita. Desde que Toledo la reglamentó ninguno de los Virreyes que le sucedieron se atrevió a poner en duda su licitud y sólo llegaron a deplorar los abusos que se cometíon en este servicio $\mathrm{y}$, sobre todo, la disminución que ella cau. saba entre los indios. Al estado llano ó al clero pertenecían quienes la condenaron y tuvieron por injusta y hasta el trono llegaron estas voces, pero en las esferas oficiales, tanto en Lima como en Madrid, la respuesta que se daba a estos alegatos no era otra sino decir que sin la mita no habría plata y sin la plata no podría sostenerse el Reino.

El Conde de Lemos en su parecer nos dá una relación exacta de lo que era la mita en su tiempa y vá señalando una por una todas las arbitrariedades que se cometen con los indios obligados a ella, desde su numeración y enrolamiento hasta que llegan a Potosí. Aquí se detiene y como en resumen dice: "Con esta opresión y tiranía se a continuado la mita de Potosí que han lamentado muchas personas celosas del servicio de Dios y de V.M., teniendo por injusta esta ocupación y contraria al derecho natural". Refiriéndose luego a los abusos que en su tiempo se cometían, expone las medidas que tomó para hacerlos desaparecer y las dificultades que le opusieron para ponerlas en práctica. Apoyándose en las disposiciones tomadas en favor de los indios, llega a la conclusión, después de haberlo consultado con el Procurador de los Mineros y el Visitador D. Alvaro de Ibarra, que S.M. debe mandar que se quite desde luego la mita de Potosí y que acudan a las labores del cerro los indios que voluntariamente quieran trabajar. En caso extremo, pide, por lo menos, que se aprueben los tres puntos que propone para el alivio de los mitayos. Con sólo unos meses de anticipación, el 7 de Febrero de 1670, escribía a la Reina, que si los medios que proponía no eran a propósito, se lo avisasen, "que con eso no recaerá, dice, sobre mi conciencia la tiranía con que son tratados los indios y justamente se debe recelar que las piedras de Potosí, en algún tiempo, rompan en sangre de in. dios, pues demás de haber muerto muchos del continuo trabajo, los que mejor libran sclen tresquilados y azotados, después de haber estado en lorgás y rigurosas prisiones y haberles vendido sus pobres alhajas, frutos y ganados para enterar en plata los indios faltos, como si fuese de su obligación".

Con esta libertad se dirige al Monarca, porque para él este asunto es de conciencia' y, como en otra carta dice, él no ha venido a las Indias a arriesgar su salvación, consintiendo que se continúen todos los agravios que se cometen por razón de la mita. Esto último nos dá motivo para suponer que en su ánimo debió influir tanto el V.P. Francisco del Castillo, varón santo e ilustrado por Dios, a quien escogió por confesor, apenas llegado al Perú, como la opinión que en la materia defendían los PP. de la Compañía, 
testigos abonados de todo cuanto ocurría en Potosí y en las Provincias obligadas a la mita. El Conde no llegó a visitar la villa Imperial, pero en Laicacota y en San Antonio de Esquilache pudo darse cuenta de lo que eran las labores de minas y en el Collao pudo palpar la desolación causada por la mita. Un deber ineludible le movió a tomar la pluma $\mathrm{y}$, deseando reforzar su parecer con el juicio de letrados, lo comunicó con las Religiones todas $y$ en sus respuestas, tres de las cuales aquí insertamos, se vé claramente cómo no disentían un punto de la opinión del Conde y alababan su celo $y$ decisión en poner remedio $\alpha$ un mal ya envejecido.

Cierra la serie de pareceres que hoy damos a conocer el que dió al Gobernador de Huancavelica, D. José Santiago Concha, en 1724, el P. Manuel Toledo y Leiva, Superior entonces del Colegio que en dicha villa poseía la Compañía. Dió motivo a dicho parecer la R.C. de 6 de Diciembre de 1719 en que S.M. mandaba consultar con hombres prócticos y de conciencia si sería conveniente o no continuar la mita de indios forzados, así en Potosí como en Huancavelica. El P. Toledo fué uno de ellos y respondió con este papel. Por lo pronto advirtamos cómo subsiste siempre el escrúpulo de la licitud de la mita. Y aun dado caso que no se dudara de esto, cómo son ciertos los males que de ella se siguen y las injusticias que se cometen, pues si nada de esto hubiera no se explica tanta preocupación. El escrito del $\mathrm{P}$. Toledo lo confirma, porque el cuadro que nos traza de la mita en el S. XVIII no difiere del que ofrecía en los siglos antecedentes.

El autor es testigo abonado de lo que refiere, pues ha vivido en Potosí y conoce toda la comarca altoperuana, de donde es oriundo. No nos detendremos a dar su biografía, pues él nos la ofrece en las primeras páginas. Divide su razonamiento en tres capítulos: en el primero defiende la conveniencia de suprimir la mita forzada; es el más extenso y el de más nervio. sobre todo, cuando rebate la opinión de la pretendida ociosidad de los indios, amparándose en ella para justificar el trabajo forzoso de las minas: en el seguncio, se retracta, pues intenta probar que es conveniente haya mita forzada de indios: es el menos extenso y el de más débil argumentación; su principal argumento es el tan repetido y manoseado de que sin mita forzada desaparece la riqueza del Perú. Si se compara lo que aquí dice con lo dicho en el capítulo primero, no puede menos de reconocerse que incurre en contradicción, pues allí ha afirmado que otras muchas minas del Perú y más productivas que las de Potosí de aquellos años, se trabajan con indios voluntarios. Finalmente, en el capítulo tercero y último se declara partidario de la prosecución de la mita siempre que se quiten a los mitayos otras pensiones que sobre ellos gravan. También en esta parte deja bastante que desear. En primer término, las pensiones de que habla son: exoneración del tributo que pagan a S.M., que los Corregidores no les carguen con otros trabajos, que los curas no les exijan derechos excesivos, que se tenga cuidado en atenderles en sus enfermedades en el Hospital y se guarden, en fin, las Ordenanzas de la mita dadas en favor de los indios. No se necesita mucha perspicacia y conocimiento de la materia para caer en la cuenta de que todo cuanto exigía el $P$. Toledo les era debido a los indios en justicia. ¿Por qué habían de pagar tributo, pesando sobre ellos una carga tan pesada como la de la mita? Exigir que los Corregidores no les ocupasen no era sino pedir aquello a que estaban obligados y les prohibía la misma ley. Tampoco los Curas debían excederse en reclamar los derechos de estola y si lo hacían incurrian en falta grave y estaban obligados a restituir. Atender $\alpha$ los indios enfermos no sólo era un acto de caridad cristiana y de la piedad más rudimentaria sino obligación natural de los que los tomaban a su ser- 
vicio, comenzando por el Rey y de ahí que éste hubiese ordenado que en todos los asientos mineros se levantase un Hospital.

Estas deficiencias y aun el tono general del parecer del P. Toledo nos demuestra cuán poderosa había sido la costumbre para adormecer el sentido de justicia y cuán lejos se estaba de la sana libertad con que en los siglos precedentes se hablaba de las órdenes del Monarca, cuando estas no se ajustaban a lo que exigían la razón y la conciencia El retroceso es manifiesto $\mathrm{y}$ de él podrían citarse otros ejemplos. Con todo, el parecer del $\mathrm{P}$. Toledo no es desdeñable, tanto por los datos que aduce sobre la mita de su tiempo como por la defensa que hace del indio $y$ porque en él se reflejan muchas de las ideas corrientes en su tiempo sobre el tema.

\section{VIII}

De intento hemos dejado para el fin de este trabajo la mención del $\mathrm{P}$. Diego de Avendaño, el ilustre teólogo y jurista que en su Thescrurus Indicus nos legó una monumental Suma de todas las cuestiones que se relacionan con este Nuevo Mundo y atrajeron la atención de los teólogos, canonistas, moralistas ó especialistas en derecho. En la dicha obra, hoy un tanto olvidada por el hecho de estar escrita en latín y por haber enrarecido, Avendaño dá su parecer sobre todas ellas con una competencia, solidez de juicio, caudal de doctrina y precisión que admiran.

De los seis tomos en folio que constituyen el Thescurus Indicus, el primero y acaso el quinto son los que nos interesan. Una breve síntesis de las cuestiones allí ventiladas nos servirá para conocer el pensamiento del autor. Comienza por preguntarse si se han de graiificar los servicios de los conquistadores y cómo, (Tom. 1, Tít. 1, Cap. V). Responde que merecen en justicia ser recompensados, ahora halla intervenido un pacto ó no con la Corona, pues su trabajo y el riesgo que corrieron merece ser gratificado $y$ en la proporción correspondiente a su esfuerzo y diligencia. Esta aserción es una tácita aprobación del sistema de encomiendas. Declara, sinembargo, que no consta igualmente si han de ser perpetuas, aunque es indudable que deberían extenderse $\alpha$ las hijos y nietos, por lo menos. No vé dificultad en que las encomiendas se concedan también a personas que no hayan sido conquistadores, pues siendo las encomiendas bienes pertenecientes a la Corona, ésta puede disponer de ellos a título de donación justa. Con todo, no seria equitativo, otorgarlas a quienes gozan de gran fortuna, habiendo otros muchos beneméritos de peor condición, pues los tributos recaerían sobre ellos y la justicia distributiva exige que las cargas de la república se repartan proporcionalmente $y$ no vengan a pesar sobre algunos $\alpha$ diferencia de otros. Finalmente, piensa con Solórzano Pereira, que las encomiendas deben darse con frecuencia a los beneméritos de Indias, pues estos tienen mejor título para ello, si bien es verdad que no les haría injuria el Monarca si las diese a otros.

Sobre la esclavitud de los indios (Tom. I, Tít. 1, Cap. 1), afirma claramente que no pueden ser hechos esclavos, salvo el caso de guerra justa, como sucede en Chile $y$, aun en este caso, sólo a los adultos que fueren hallados con las armas en las manos. Cree, sinembargo, que no se debe dar ocasión a esta lucha, pues muchas veces se ha exasperado a los indios $y$, por esta razón, conviene usar de clemencia con los cautivos 24 . Pasando

(24) En el Tom. V, N9 636, vuelve sobre el asunto $y$, sin retractarse de lo dicho anieriormene, declara que los indios de guerra fuesen reducidos a esclavitud temporal. 
luego a tratar de la mita, (Tom. I, Tít. I, Cap. XII), dice que es cuestión resuelta y. por lo tanto, así la considere ilícita o no, su parecer, después de cuanto se ha dicho de una y otra parte, no vá a decidir el asunto. No obstante, confiesa que la sentencia que la tiene por lícita sólo tiene probabilidad extrínseca, pues sus argumentos no convencen. Agrega que los mismos Reyes no llegan a desvanecer todo escrúpulo al consentirla y, en su sentir, este es un argumento de que carecen de rozones bastantes para escudarse tras ellas. 25. Esto supuesto, si la mita en general no puede llamarse justa con mayor razón la de Huancavelica, pues aun los contrarios no la defienden.

Sobre el servicio personal (Tom. I, Tít. I, Cap. XIII), no es menos explícito. Lo considera injusto y considera que no puede invocarse en su farvor la costumbre, tanto más que las leyes que lo prohiben son terminantes. Empero, en la próctica hay que usar de discreción al condenarlo, sobre todo cuando los que hacen uso de él están de buena fé. En el Capítulo siguiente vuelve sobre lo mismo, aunque bajo el nombre y con la calidad de trabajo forzado. Este lo juzga lícito siempre que se trate de labores necesarias para el bien público, como sucede, p. ej., en el servicio de tambos y de correos o chasques. No lo autoriza en los obrajes, ni en favor de particulares y tampoco para el recojo y plantación de la coca. Ya en su tiempo muchos opinaban que debía proscribirse del todo el uso de esta hoja y los Concilios Limenses clamaron contra ella. El P. Avendaño reprueba su uso, sin duda, pero cree que no puede prohibirse que sea objeto de comercio. También se discutía si era lícito o no el yanaconaje, tal cual entonces se practicaba, pues a algunos les parecía una suerte de servidumbre. No lo condena, siempre que sea voluntario, pues a cada cual le es lícito vender, digúmoslo así, sus servicios, aunque sea de por vida, a cambio de otras ventajas. El hecho es que muchos indios preferían servir de yanaconas a estar sujetos a la esclavitud de la mita ${ }^{26}$.

En el mismo volúmen (Tít. VII, Cap. 2), vuelve $\alpha$ ocuparse de los encomenderos, estableciendo las obligaciones que gravan sobre ellos y demuestra que las principales son dos: Ia defensa de sus indios y su adoctrinamiento en la fé católica. Si faltan a una u otra están obligados a restituir los tributos que hayan percibido y se les puede despojar de la encomienda. Tal es ia doctrina encerrada en sus libros $\mathrm{y}$. como vemos, ella no difiere de la enseñada por otros autores de la Compañía, la cual se constituyó, por el mismo caso, en defensora del indígena $\mathrm{y}$ con su actitud, en el púlpito y el confesionario logró suavizar su condición y en muchos casos obtuvo que se reparasen los agravios que se le habían inferido, sea por los particulares sea por los mismos gobernantes. De este modo, en esta lucha por la justicia, los jesuitas ocuparon el puesto que les correspondía y hasta su extrañamiento deestas regiones se mantuvieron fieles a esta consigna que les atrajo el amor y las simpatías de los indios.

\section{Ruben Vargas Ugarte S.J.}

(25) En el Tom. I, Tít. X, en donde trata de los Mineros y Azogueros, hace una lista de los delitos ó pecados en que incurren ó suelen incurrix los que a este negocio se dedican.

(26) En el Tom. V. Parte X. No 605 y s. se plantea la cuestión de si es justo o no el salario con que se retribuye en los valles de Trujillo el trabajo del indígena (4 reales) y conclu. ye que es del todo insuficiente. 


\section{Parecer del P. Diego de Torres sobre si conviene la perpetuidad y con qué modo se deveria hazer, conviniendo, (1601).}

Para responder a esto es necesario suponer dos cosas certíssimas que la experiencia $\alpha$ enseñado $y$ dirán las personas que han estado algunos años en aquel Reyno: La primera, que esté a pique de acabarse aquel Reyno con la gran disminución de los yndios, los quales con las bexaciones $Y$ trabajos ymmensos y ordinarios de minas, traxines, obrajes, trapiches, labores de biñas $Y$ sementeras, servicios de tambos, ciudades $Y$ obras públicas y andar casi siempre apcurtados de sus mugeres, van en notable disminución $Y$ rruyna; de todo lo qual los principales ynstrumentos y ministros son los corregidores de yndies y los caciques que los avian de defender y amparar. El $2^{\circ}$ supuesto es: que como en aquel Reyno ay tantos hombres ociosos y tantos descontentos de que, aviendo sus pasados ganado aquel Reyno, ellos mueren de hambre y no les dan de comer, tratan muy de ordinario de ynquietudes y sediciones $-\mathrm{y}$ las yntentan y como la gente perdida y bagabunda crece y también los descontentos con la dificultad- que ay de alcanzar no sólo mercedes sino paga de servicios، el Reyno está en grande riesgo de que subceda algún alboroto y prenda tal fuego que ó no se pueda apagar ó sea tarde y con mucha costa, como avría sucedido en lo de Quito, si tubiercm caveza de base ó el Marqués de Cañete no tubiera tanta y tan gran grudencia $\mathrm{y}$ como los que entonces sirvieron padecieron tanto $\mathrm{y}$ no fueron premiados, sino qual ó qual, con razón se podría temer que avría pocos que acudiesen a sus obligaciones.

De todos los daños del primer supuesto es la causa y raiz principal estar los yndios como obejas sin dueño, faltándoles quien los defiendia y ampare, porque los encomenderos que lo devian hazer no tienen mano para ello, ni viven en los pueblos de los yndios, sino en las ciudades de los españoles y como tienen los yndios de prestado, trátanlos como viña alquilada, destrutándolos, por grangear que dexar a sus hijos y porque los corregiảores los dexen grangear y los caciques les ayuden a ello, ellos también disimulan los agravios que los Corregidores, Caciques y curas hazen a los yndios. Lo qual no harian, teniendo los yndios perpetuos y asi la primera razón y fundamento de la perpetuidad es la conservación de los yndios, defendiéndolos los encomenderos y amparándolos en todos los agrabios dichos, mirando por ellos como propia y única hazienda suya y de sus hijos y sucesores, no consintiendo que corregidores, caciques, sacerdotes ni pasajeros los molesten ni agravien y ayudándoles a que, como sus haziendas. 
la aumenten, como lo hacían los primeros encomenderos y conquistadores, que, como fueron los primeros poseedores y temían los crvían de perder $Y$ ver en poder de otros dueños y señores, los ayudaban y defendían y amaban como $a$ sus hijos y les dejaron limosnas y comunidades de mucho balor.

La segunda razón es que, repartiendo todos los yndios del Perú y encomendándolos, dando a cada doctrina su encomendero, que serán más de mill y ducientas encomiendas y encomenderos $y$, siendo estos los sucesores de los conquistadores y la gente más principal, aquel Reyno queda se. guro y llano y libre de sediciones y alborotos, perpetuamente, porque estarán contentos y quietos los que agora no lo están y todos los hombres y principales, precisados y obligados a la defensa y no solo ellos sino más de otros doze mill hombres, deudos, hijos, criados y paniaguados que están a su sombra, no tendrán nada que pretender con las alteraciones. porque sin ellas tuvieran lo que sin ellas aun no era posible conseguir y no puede aver tal que se atreba, saviendo que todos los dichos an de morir en la defensa y los mestizos, de los quales pudiera aver rezelo alguno, no les pasará por ymaginación tal cosa, porque o serán criados, hijos, deudos de los encomenderos.

$3^{a}$ De esta razón se siguen otras conveniencias. La $3^{a}$ que no serán menester Corregidores ni lanzas y arcabuzes ${ }^{1}$ y Su Magestad ahorrará dellos cada año más de ducientos mill ducados que agora se gastan. No serán necesarios Corregidores, porque estos se ponen por dos fines que con los encomenderos cesan: uno para cobrar las tasas y tributos $\mathrm{y}$, estando el encomendero en su pueblo, allí se le pagará o sino, los mesmos yndios llevarán a los pueblos de españoles para que allá se pague, que parece necesario. El $2^{\circ}$ fin es porque defiendan a los yndios de los agravios de los caciques y pasajeros, y teniendo el corregidor 20 ó 30 pueblos, y, no pu diendo asistir más que a uno, mal defenderá a los yndios, de más que, camo todos confiessan. sólo el Corregidor haze más daños y agravios a los yndios que todos los pasajeros y los encomenderos, viviendo en sus pueblos y teniendo por Su Magestad a su cargo la defensa de los yndios, avrá la sin comparación mejor, cuidarán que no salgan de sus pueblos, guardarón el Reyno y no serán necesarios lanzas ni arcabuces.

$4^{\alpha}$ Que no se atreberón en el Perúl los españoles a matar unos $\alpha$ otros con la facilidad que agora, porque en saliendo de las ciudades no se atreverán como agora a cometer semejantes delitos.

$5^{a}$ Una de las cosas que en el Perú pide mayor remedio es el reformar las Reducciones que hizo Don Francisco de Toledo, cuya conservación ymporta sumamente al bien temporal y espiritual de los yndios, con cuyas ausencias se van perdiendo las Reducciones y poblaciones porque nadie cuy$\mathrm{da}$ del remedio con calor $\mathrm{y}$ hazerlo an los encomenderos siendo los yndios perpetuos, y conservaránlos y augmentaránlos, que no es negocio dificultoso, sino fácil, aviendo persona que le duela y cuyde de ello con veras.

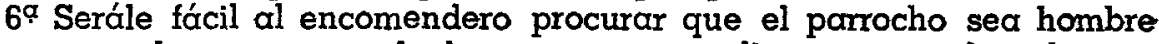
de buen exemplo y que sepa la lengua y que predique a menudo a los yndios y haga su doctrina, como la a de hazer y quando no, avisará al Obispo lo remedie.

7. Serále fácil al encomendero remediar las borracheras y pecados públicos de los yndios, viviendo entre ellos y estándole esto encomendado

(1) Guardia de Lanzas y Arcabuceros, fuerza armada á las órdenes del Virrey 
por Su Magestad y los caciques que suelen ser los principales delincuentes en esto no lo serán con la presencia de su amo.

8. Remediarón por su ynterés los encomenderos dos abusos que ay entre los yndios, con gran perjuicio del bien común. Uno es, que las yndias, porque sus hijos no paguen tasas ni acudan al servicio personal como los demás yndios, cásanse con mestizos, españoles, negros, mulatos y otras mezclas, y hazen dos daños, uno que cada una de las que así se casan quitan que aquellos hijos ayuden a la comunidad en los servicios y tributos y ponen $\alpha$ los yndios y a la comunidad otros tantos enemigos y cargas quantos son los hijos que tienen, y asi con mucha razón estava mandado en las Ordenanzas antiguas no se casasen las yndias sino con yndios y el abuso que ay en lo contrario los encomenderos lo remediarán, procurando que las yndias se casen con yndios, por no perder el deudo y tributo de sus hijos, y la ayuda que la comunidad puede tener dellos, siendo yndios. El $2^{\circ}$ abuso es que muchos yndios se hazen officiales y yanaconas de los españoles, $y$ se ausentan, $Y$ con eşo se pierde el tributo $y$ por ser oficiales, dejan de ayudar a la comunidad, y así se deve moderar esto y nadie lo hará con los encomenderos.

9. Aprenderán los yndios la lengua española y buenas costumbres y aficionándose más a los españoles, recibiendo buenas obras y conociendo siempre por señores a los de una familia y acudirán mexor a socorrerse y ayudarse dellos que agora que, como mudan tantos señores, no les tierien amor.

10. Las causas principales por las quales no se an reducido y concurrido tanta multitud de provincias como ay en el Perú de ynfieles y muy rricas de oro son dos. La primera el saver los malos tratamientos y agravios que los yndios christianos reciben de los españoles. Este ynconveniente cescrá en gran parte con la perpetuidad, como está dicho y los ynfieles con ver que por esta camino se hazen buenas obras a los fieles, perderán el riedo y orror que cgora tienen a los españoles y rreduciránse. La $2^{\text {a }}$ causa de no se aver conquistado es que los españoles viendo los grandes gastos de las conquistas y el riesgo, que no les an de dar los yndios sino por dos vides no quieren yr a conquistar, sino gente perdida que ni tiene que gastar ni porder y no van sino a hurtar y no guardan órden, ley ni ynstructión y huzen las conquistas del todo ynjustas y tiránicas. Pero si los yndios se uvierar. de dar perpetuos, fueran a las conquistas gente principal $y$ honrada que guardará las leyes y instructiones y procurarán atraer por bien y buenos modos a los yndios y aunque de esta manera no lo conquistaran, cuando edificaran pueblos, a los quales pudieran salir los Religiosos más fácilrni-nte que agora a predicar y convertir los fieles y tubieran mayor seguridra $y$ pesando bien esta razón deve hazer fuerza por ser en materia tan g. ave. La $11^{q}$ razón que parece confirma las demás es, que aviendo quarenta años y más que se trata de esta materia y siendo las personas más grabes del Perú de parecer que se hiziese la perpetuydad, no se a hecho, diciendo que no convenía a la conservación y bien die los yndios $y$ seguridad de el Reyno y la experiencia a enseñado lo contrario, que los yndios por este modo an venido en gran diminución, $y$ en el Reyno se a yntentado muchas sediciones y alborotos y asi no a sido bueno este modo de pensar siempre que las encomiendas se dieren $1^{\circ} \alpha$ los conquistadores. $2^{\circ} \alpha$ los qus huviesen servido bien a su Magestad en el mesmo Reyno. $3^{\circ}$ los que le uvie. sen servido en otras partes. $4^{\circ}$ la gente noble y principal.

Quanto a la cantidad de yndios: que no pasasen de aquellos que puedam dar asta tres mill ducados de rrenta y $\alpha$ otros se diesen menos, y los 
que por sus días o de sus hijos tubiesen más los gozasen y después se diesen $\alpha$ sus nietos, repartiéndolos al modo dicho, $y$ si con la vida del padre uviesen de cescr $y$ él quisiese que, después de su vida, se diesen a sus hijos y que se le encomendasen, luego se hiziese, al modo que con los demás, siempre $y$ cuando que cada uno suceda quando buenamente se pudiere en los yndios de sus pasados y mandando que ninguno tenga dos encomiendas.

La sucesión de las encomiendas avia de ser sólo por linea recta, ago ra tuese baron agora muger, y no avia de pasar al colateral sino componiéndose de nuevo como los demás. pero devian ser preferidos los deudos más cercanos, solo en $2^{\circ}$ ó $3^{\circ}$ grado y siempre que muriese el encomendero, devia el hijo o nieto mayor acudir al Virrey a que le pasase la encomienda, saviendo todos que si el tal heredero fuese muy desbaratado y vicioso que no se le dará la encomienda, pero no se le devia quitar sino en caso muy raro y con parecer de toda la Audiencia, aviendo el fiscal en nombre de Su Magestad convencídolo de que no era capaz de ello y no admitiendo en el pleyto y causa para seguirla al sucesor ni a otro por el, sino al fiscal de officio, para que con este freno viviesen bien $y$ para que, después de aver entrado en las encomiendas, hiziesen lo propio $y$ no se desbaratasen, devian sıñalarse algunos casos grabes y raros en que perdiesen las encomiendas y para remedio de otros excesos y escusar mexor los corregidores, devíase guardar la ordenanza de las Audiencias de que siempre andubiese en el districto de cada una visitando un oydor, pero con poca gente y gasto, porque no molestasen a los encomenderos ni a los yndios, dándoles nuevas ynstructiones de cómo an de visitar.

Los encomenderos devian vivir en sus pueblos con authoridad y mano para poder prender delinquentes y rremitir a las ciudades con los ynfor mes y para poder ymbiar cartas de Justicia contra los delinquentes, quando conviniese y para hazer que los alcaldes de los yndios hagan justicia entre ellos, encargándoles seriamente en las visitas de encomiendas la defensa y amparo de los yndios y no permitir se les hagan agravios, que no consientan se ausenten $y$ procuren se reduzcan los ausentes, todo esto como a veräaderos protectores suyos, mandándoles ansimesmo que no se sirvan de negros ni mulatos, por casar; que todos los mestizos que uviesen procuren deprendan oficios o que ellos y las mestizas sirvan, no consintiendo que, éstas, anden en avito de yndias, que procuren que' los curas que se señalasen a sus yndios sean buenas lenguas y hombres de edificación; que los encomenderos den a S.M., por via de servicio y la pensión o feudo, cada año de la tercera o quarta parte o lo que en esto se debe $y$ pide consideración y traza de los SS. que lo tienen a cargo y miraren mejor; sólo parece necesario advertir que se vaya con consideración de minorar las tasas y tributos de los yndios porque están muy subidas para tan pobres y que solo tienen para ello y su sustento su trabajo y sudor.

$2^{\circ}$ Parecía muy conveniente que de lo que cabe y queda al encomendero, o de la gruesa del tributo y tasas se sacase una moderada cuota o pensión para que en cada cabeza de obispado se fundase un Collegio Seminario de hijos de caciques y en las demás partes o ciudades que el Virrey juztgase, y que como los curas den para los seminarios de los obispados. $3^{\circ}$ que los encomendiros para estotro diessen otro tanto y también de las comunidades lo que pareciese conveniente. A menderos a Su Magestad la $3^{q} \circ 4^{\alpha}$ parte de las rrentas y aviendo de proveer los Virreyes las encomiendas que vacaren, por falta de succesor y pudiéndose acudir a él, a que cuele y dé a los succesores las encomiendas, arto recurso queda en el Reyno a el Virrey $Y$ bien tiene en qué hazer merced, 
expecialmente que, repartidas todas las encomiendas y yndios della, como por lo dicho parece que conviene, pocos quedarán por pagar y satisfacer y contentar, especialmente teniendo grande fuerza $y$ rigor en que no pase al Perí tanta gente que, por una parte, acá haze grande falta lo que en ella consumen $y$ asuelan a los yndios y como gente ociosa tratan sediciones y alborotos $y$ viven con gran escóndalo, $y$ asi convenia bien para la seguridac de el Reyno que todos executasen allá los oficios que tubieren acó y que. como se ha apuntado, los mestizos sirvan o tengan officios, que es un género de gente perjudicial y aparejado para sediciones: asi se abia de executar el medio que se apuntó en el $\mathrm{N}^{\circ} 3$, de que todas las yndias se casen con yndios, con orden de que los que naciesen de yndios sigan la condición de los yndios en el avito y servicios $\mathrm{y}$ tributos con lo cual cescrán de aquí adelante en pocos años los mestizos $\mathrm{Y}$ se ahorrarian muchos pecados de españoles y mestizos con yndias.

En lo que toca a las lanzas y arcabuzes que agora ay, puédeseles conservar y que como van vacando, se vayan consumiendo o hazer con ellos asiento en encomiendas, satisfaciéndoles lo que dexaren.

Para más seguridad del Reyno y contento de los que viven ien él y bien de los yndios, convernia que los segundos hijos de los encomenderos se criasen en los collegios seminarios de los obispados, a costa de sus padres y que tuesen preferidos en las doctrinas y beneficios,por saver mejor las lenguas y averse criado en virtud y letras, y juntamente que los de las yndias no vengan acó a pretender ni dando prevenda alguna a persona que no sea de aquel Reyno, y si pareciere conveniente se podrían también bender allá algunas rentas de Su Magestad, comó de estas partes, de las encomiendas que $\mathbf{S u}$ Magestad ternó, con que no avrá persona allá que no esté prendada y defienda el Reyno, con la qual carga se supone se han de dar todas las encomiendas $\mathrm{y}$, si pareciere, también las demás rentas que se bendieren, $\mathrm{y}$ officios y mercedes que se hizieren.

Conveniente parece que seria ordenar que los indios que por la predicación se convirtiesen de nuevo no se encomendasen a persona alguna ni tubiesen obligación $\alpha$ servicios personales ni tributo, por 20 ó 30 años, con que sólo sustentasen a los sacerdotes que los hubiesen de doctrinar y que, passado el dicho tiempo, la tasa fuese muy moderada y servicios personales también, porque con eso $y$ el buen tratamiento que viesen se hace $\alpha$ los christianos se facilitase su conversión.

De todo lo dicho se infieren algunas razones que confirman más la importancia de la perpetuidad. La primera, que haciendo y prefiriendo en las encomiendas a los descendientes de los conquistadores y haciéndoles alguna gracia de que paguen menos que los demás a Su Magestad, se descarga su Real conciencia y de sus pasados que todos sienten ay obligación a hacer merced a los sobredichos y gratificar los servicios de sus antepasados que con tanto riesgo y trabajo ganaron y conquistaron aquella tierra y por otro camino y modo se hará esto mal.

$2^{\circ}$ Se infiere que por dicho medio de la perpetuidad no sólo Su Magestad conserva y sustenta en paz aquellos Reynos, pero se augmenta su Real patrimonio $\mathrm{y}$ hacienda, ahorrando, por una parte, más deducientos cinquenta mill ducados de Corregidores, lanzas y crcabuzes y los grandes gastos de las querras, pero terná con los dichos feudos y tributos más de quatrocientos mill ducados de rrenta más que agora, y esto cun sin el servicio que al principio de las encomiendas se le a de hacer.

Ha más de 70 años que se trata si converná que se perpetúen los repartimientos de indios que ay en todas las Indias en las personas que los 
tienen, encomendados por 2 ó 3 vidas y también los que están en la Corona Real, si es más conveniente que asi como vayan vacando se pongan en la Corona y la órden y asiento que en esto se podría dar y sobre ello se an tomado en este tiempo diversos pareceres de muchas y muy graves personas $_{4}$ y haviéndose juzgado que convenia hazer la perpetuidad de toda la tierra del Perú, como por su parte se havia pedido $y$ que se podria sacar gran suma de hazienda para las necesidades y guerras que se ofrecían $\alpha$ Su Magestad y que importava para la conservacion, acrescentamiento y seguridad de aquellas provincias, se embiaron comisarios el año de 60 al Perú con comisión y facultad muy cumplida para ponerla en execusión $y$, queriendo usar de sus comisiones hallaron tantas dificultades y contradicciones $Y$ tanta incertinidad en los presupuestos que se hizieron para esta resolución, que habiendo avisado a Su Magestad (que aya gloria) de lo que pasava y les parescia, tuvo por bien mandarles que se volviesen, como lo hizieron, sin executar cosa alguna, y despues acá se a tratado desta materia diversas vezes en el Consejo de Yndias $y$ en juntas particulares $y$ se an visto los papeles antiguos y modernos que tocan $\alpha$ ella, que son muchos y se an hecho diversas consideraciones a Su Magestad, aprobando algunos medios y reprobando otros que se an propuesto y se an tomado aparte paresceres por escripto de los ministros que en estas Juntas han concurrido $y$, aunque difieren unos de otros, los más dellos concurren en que conviene que aya perpetuidad, y del mesmo parescer fueron los comisarios del Perú, más difieren en la forma en que se deve hazer esta perpetuidad.

$\mathrm{Y}$ haviéndose hecho relacion de todo a Su Magestad (que aya gloria), no se acavó de resolver en ello y a más de doze arios que no se ha tratado desia materia hasia agora $y$ en este tiempo ha avido mucha mudanza en las cosas de las Indias del estado que entonces tenían y si algunos se muestran contrarios a este parescer, deben ser de los que no tienen mucha experiencia, que de los que la tienen, muy raros son los que no digan es sumamente importante la perpetuidad, como lo dicen muchos perlados y el Virrey Don Luis de Velasco y atras muchas personas celosas de la conservación de aquel Reyno y servicio de Dios Nro. Señor y de Su Magestad, especialmente agora con la puerta que se ha abierto $y$ principio que se ha dado para que todas las buenas encomiendas del perú se den y provean acó, lo qual seró infalible de aquí adelante, como las necesidades, servicios y favores de acá son tan grandes y estón tan cerca de Su Magestad. Y los graves inconvenientes que esto tienen son muchos $y$ sin otro remedio alguno que el de la perpetuidad y repartir de una vez todas las encomiendas de aquel Reyno y contar a todos los del $y$, por ventura, esta es de las principales razones que persuaden a la perpetuidad, porque con una encomienda que acá se da se contentan quatro o seis personas beneméritas de allá, los quales no tienen duda sino que socorrerán mejor las necesidades de los indios, viéndolas, que no los que estuvieren lexos y no los hechan de ver.

Biblioteca Real. Madrid, Ms. 2-C-3. 
Breve Relacićn de los agravios que reciven los indios que ay desde cerca del Cuzco hasta Potosí, que es lo mejor y más rico del Perú, hecha por personas de mucha experiencia y buena conciencia y desapasionadas de todo interés temporal y que solamente desean no sea Dios N.S. tom ofendido con tomtos daños como los indios resciven en sus almas y heziendas y que la conciencia de Su Magestad se descargue mejor y sus Reales Rentas ro sean defraudadas en nada sino que antes bayan siempre en continuación (1596).

En las Provincias que ay desde Potosi hasta cerca del Cuzco an ydo los yndios en tanta diminuycion questan los pueblos desiertos y los tambos sin gente ni servicio y todo tan solo y desamparado que es la fama dello: de donde dexados otros daños nace uno harto grande a la hazienda Real ques no poderse cobrar en muchas partes sus tributos y tasas y aver muchos recargados por lo qual será justo y de mucho servicio de nuestro Señor y Su Magestad que las personas graves y de saver asi eclesiásticas como seglares den aviso destos daños y sus caussas y del remedio que podra aver a quien estubiere $\alpha$ cargo el podellas remediar y si fuera menester tambien a Su Magestad: pues en todo lo ques servicio de Dios y suyo y continuacion de sus Reales Rentas y satisfacer agravios le es muy grato qualquier noticia que se le dé.

Las principales caussas de averse ausentado tantos yndios de sus pueblos y averse huydo a diferentes partes son dos, aunque ay también algunas otras de harto momento que despues se diran: La primera es el yr a Potossi cada año tantos yndios a la labor de las minas que es la que dizen la mita de Potosí. y la segunda, el trajinar tan continuamente y con tanto exceso. En primer lugar se dirá lo que sea esta mita y los daños que padecen $\mathrm{y}$ lo que se podra temer de todo ello, y despues se pondra el remedio que a parecido podra aver a personas baqueanas $\mathrm{y}$ de experiencia $\mathrm{y}$ de muy buen conoscimiento y conciencia en todo lo qual es bien se ponga desde luego que en la hazienda Real no $\alpha$ de aver diminuycion sino antes más continuacion. 


\section{Cap. Primero.-En que se trata de la mila de Potosí y de los daños y agravios que los yndios reciven en ella.}

Cossa notoria es a todo el mundo la gran riqueza de plata que a salido deste Reyno del Pirú la qual principalmente $\alpha$ salido del cerro y minas de Potosi. este cerro esta apartado de lo poblado de los yndios que ban a el. lo mas cerca como quarenta leguas $y$ lo más lejos como ciento $y$ tantas leguas y la dispusicion de la tierra es de manera que la avitacion de los yndios se estiende a lo largo y no al un lado y otro de Potosi: de los pueblos o Provincias ban cada año a la labor de las minas cierto numero de yndios que son como treze mill $y$ aunque de algunos pueblos enteran los yndios el numero que estan obligados a dar, los más no cumplen la parte que les toca porque no pueden y para que mejor se entienda lo que se pretende pornáse aqui lo que en la Provincia de Chuquito se haze cada año y los yndios que ban y buelben y lo que en ella passa. Eso mismo se a de jusgar de las demas, como en la Provincia de los Carangas, de la de Paria, de la de los Pacajes y esta de Humasuyo y de todo el collado y canas $y$ canches.

Esta Provincia esta repartida en siete pueblos y en toda ella en la ultima revisita que se hizo agora 16 años se hallaron como 17,000 indios de tasa de 18 á 50 años, contando los presentes y ausentes de todos estos, que aunque algunos años atrás no iban sino mil y cien indios, mandó D. Francisco de Toledo, Virrey que era entonces destos Reynos que cada año fuesen 2,000 y 200 y añadió 200 á los dos mill; todos estos hordinariamente ban con sus mugeres y hijos y el numero de todos ellos siempre pasa de siete mill almas, cada yndio destos lleva por lo menos ocho o dies carneros de la tierra $y$, algunos pacos o alpacas para comer que es otro género de ganado; otros de más caudal llevan treynta y quarenta carneros, en ellos llevan su comida y ollas y los chuses en que duermen que son sus frazadas y sus esteras para defenderse del frío, porque duermen siempre en el cam. po. y unos llevan más y menos ganado conforme a su caudal y tomado todo junto ordinariamente passa de quarenta mil cabezas de ganado y casi siempre llega a quarenta y cinco mill $y \alpha$ avido año de cinquenta y tres mill. Las quarenta mill con el chuño y maiz $y$ harina de quinoa y cecina que ellos dizen charqui $\mathrm{y}$ sus bestidos nuebos $\mathrm{y}$ todo valdrá más de trescientos y veynte mil pesos corrientes. toda esta gente con toda esta riqueza y camuaje vá caminando a Potosi por sus jornadas y tárdanse de hordinario en llegar alla dos messes y sera la distancia como cien leguas. la caussa de detenerse tanto es no poder llevar el ganado con mucha priesa en todo este camino comen a su costa y tambien quando buelven a sus pueblos y no por lo uno ni por lo otro jamás se les a pagado que no es pequeño el agravio que en esto ay.

Lo segundo, desamparam su patria y pueblo y su ganado y chacaras y aunque algunos encomiendan lo que dejan a sus deudos, pero quando acasso buelben lo hallan todo tan mal puesto y tan perdido que la expe. riencia les enseña ser lo mas acertado no bolver particularmente juntándose a esto otros travajos.

Lo tercero, a la partida hazen grandes sentimientos $y$ entristeciéndose unos con otros como gente que a pesar suyo desampara su patria y que ba a manifiesto peligro de su vida como luego se dirá y que con mucha razon teme no bolverá más della: otros ay que descaecidos con la memoria de los travajos que an de padecer y la pérdida que an de tener en sus hazien- 
das se entregan a vicios y borracheras. otros toman ocasion desto para dexar sus mugeres $y$ se amanceban con sus hijas o hermanas o con otras yndias y como quando llegan a potosi el cura de la Parroquia adonde hazen asiento no los conosce se quedan asi en su mal estado y quando acavado el año de su mita se huyen a los valles y se conciertan con algun chacarero queda confirmado su amancebamiento de donde a nascido pagar en la dịcha Provincia las mugeres la tasa de sus maridos sin culpa suya por siete o por ocho o diez años que quiebra el corazon ber sus llantos y lágrimas y tienen harta razon para aflixirse viéndose por una parte sin maridos y por otra obligadas a pagar la tasa que ellos deven. y de la misma manera se cobra la tasa de las hijas y hermanas de muchos yndios ausentes que no consta si ze an muerto o adonde se han huydo o lo que se a hecho dellos y paganla por entero con los mismos llantos y lagrimas que las pasadas y por muchos años.

Lo $4^{\circ}$ quando todo esta gente llega a Potosi luego se toma memoria del numero de todos y sy falta alguno y si de la gente que salió de la Provincia se huyen ciento $o$ doscientos yndios a los valles que ay a la una $y$ otra parte del camino luego enbian de Potosi un Justicia con dias y salarios para que se saque de la mesma Provincia la cantidad que faltaran y nunca ban a buscar a los que se ausentaron a los valles y con esto y con bolber tan pocos de Potosi se an ydo agotando: De manera que aunque se saquen el dáa de oy todos quantos ay en la Provincia de chuquito ni se podrá cumplir el numero de dos mill y docientos que hasta agora an ydo cada año y aunque Don francisco de Toledo señaló docientos a los dos mill para suplir las mermas y faltas y ausencias de las demas nunca se a tenido atencion a esto porque cunque no falten sino veynte yndios luego embian por ellos con dias y salarios, como esta dicho y de lo que sirben estos Jueces que asi bienen de Potosi, de algunos dias acá es de llevar sus salarios y aunque los caciques a cuyo cargo esta el dar los yndios que falten estén agenos de toda culpa, porque ni la tienen, con todo eso están obligados a la pena que es a pagar al juez sus derechos y para podellos cobrcr, aunque no hagan nada traen bastantes recados de quien los envia y de la manera que llaman estos Jueces y el nombre que les ponen no es digno de ponerle aqui.

Lo $5^{\circ}$ aviendo ya hecho los yndios asiento en sus parroquias luego los obligan a trabajar en las minas y los que acuden a esta labor por obligación llaman los indios de cédulas. Y quando un español o minero la tiene para diez o veynte indios va a sus casas y con mucho rigor y aspereza los saca azotóndolos y maltratándolos porque no van tan presto como el quisiera y si el indio que es capitan dellos no le entera el numero que la cécula reza acontece abofeteallo y maltratallo hasta que la entere. Despues que aya llevado el minero sus indios hace que entren en las minas y que saquen el metal y si no es tanto como el desea entonces es el azotallos y acoceallos con tanto rigor que afirman muchos que los azotes de las galeras no llegan $\alpha$ esto. y el pokre indio a veces no puede mas por estar la mina muy honda y cansarse si trae mucha carga y temer se caerá y morirá. Otras, porque el metal está muy duro y el que barretea saca muy poco, este rigor y asperesa, temenla los indios mucho porque a acontecido y sucede cada dia matar los españoles indios a puras coces y azotes.

Lo $6^{\circ}$ para alivio desta carga la paga que reciben cada semana son dos pesos y medio corrientes que son veinte reales, y para que mejor se entienda el agrabio que con tan poca paga reciben sera bien decir lo que - llos gastan moderándolo todo lo possible. Estos años atras a valido la ha- 
nega del chuño a veinte $y$ beinte $y$ dos $y$ beinte $y$ quatro pesos corrientes $y$ $\alpha$ mas y la de maiz a muy poco menos hechando la quenta por un mes cas me un indio por lo menos media hanega de chuño y si es de maiz mas porque este quando se cuece no crece como el chuño y quentase por esta media honega diez pesos que lo ordinario cuesta mas. gasta mas cada mes de harina de maiz por lo menos dos pesos. Come cada mes de carne una alpaca y oun es poco que siempre vale cuatro pesos, de pescado y aji y sal gastara siempre dos pesos, de leña o estiercol y de paja que llaman hichu para guisar de comer gasta cada semana un peso que esto cuesta mucho alla, al cabo del mes son quatro pesos y medio. Los mas de los indios comen cada dia dos reales de coca que claro esta que tantos millares de cestos que della entran en Potosi cada año que toda la consumen ellos, unos pues comen dos reales della cada dia y algunos real y medio y algunos y aunque pocos, un real, cuéntanse moderándolo lo possible cinco pesos por un mes. Mas se quente por un mes un peso de chicha, que más bebe un indio, pero eso no entra en esta quenta ni tampoco la fruta y otras cosas que a veces suelen comprar sino solamente lo forzoso. Todo ello monta beinte y ocho pesos y medio y no se quenta lo que gastará en ollas ni las mantas que rompe on sacar el metal y en vestirse ni la tasa que paga en un año que son treinta pesos comientes $y$ lo que gasta con su muger $Y$ hijos en dalles de comer $y$ vestillos que por lo menos gastaran tanto como el, y sobre todo esto acontece que el minero no le paga por entero lo que le deve porque dice que no cumplio ni entero su tarea y en conclusion le sale cada mes al pobre indio solo lo que gasta en su persona, con la tasa y vestidos mas de treinta $y$ dos pesos $y$ juntándose esto lo que su mujer $y$ hijos comen $y$ visten pasan de sesenta pesos y la paga que recibe seran quando mucho onse pescs y medio. La respuesta que algunos an querido dar a esto de bien poco fundamento se porna mas abajo quando se diga el remedio que a parecido a los mas experimentados y entendidos podran tener estas cosas y otras que se trotaran.

Lo $7^{\circ}$ Aunque temen los indios mucho las pérdidas sobre dichas y el rigor y azotes de los mineros y otros trabajos ya referidos también temen mucho el gran peligro que tienen en sus vidas quando entran en las minas por estar tan hondas $\mathrm{y}$ ser las entradas $\mathrm{y}$ salidas tan peligrosas $\mathrm{y}$ desgalgarse muchos terrones y piedras que descalabran o matan a los que topan, $\alpha$ otros ies ban los pies quando suben las escaleras que son de cuero, y si al que ba delante se le cae algo o el por su desgracia se deslisa suele bescalabrar y aun matar a los que vienen tras el y assi ay cada semana por lo rnenos de siete $\alpha$ ocho descalabrados, unos quebradas las piemas, otros los brazos, otros la cabeza, y otros molido todo el cuerpo, y una semana con otra ay uno y dos muertos, fuera de los que quedan en lo hondo de las minas, hechos pedazos, que no se sabe dellos. Allende desto muchas veces hay 30 y 40 muertos de una vez, unas veces más $y$ otras menos por caerse y derrumbarse un pedazo de una mina y cojellos debajo. algunos suelen quedarse medio enterrados $Y$ de las minas mas cercanas los confiesan a voces y es una lastima y compasion grandíssima ver estas cosas y ellos, que las da dia dos reales de coca, que claro esta que tantos millares de cestos que serables indios y pluguiera a Dios que no fueran tantos que convencidos con la falsu apariencia que el demonio les representa y afligidos con la memoria de los trabajos donde pierden tanta de su hacienda $y$ enriquecen $\alpha$ los demas $y$ por el temor que tienen al rigor y aspereza de los que asisten a sus tareas que son los mineros y considerando el gran peligro de sus vidas y que dejan a pesar suyo su patria $y$ tierra se ahorcan $y$ desesperan $y$ en 
un pueblo solo de la provincia a avido casi siempre un aorcado cada año y en otros mas, y todo esto se occulta y calla y se deja de dezir a quien podia remediallo. Muchos indios ay que quando les cabe su mita para ir a Potosí, que por allarse con caudal alquilan a otros y lo que por lo menos dan que algunos ay que pagan mas es lo siguiente: lo primero treinta carneros rasos que valen trescientos pesos yten doze obejas de la tierra que valen cinquenta pesos mas ocho cargas mas dan dos pares de vestidos nuebos iten dan mas los treinta pesos corrientes que pagan de tasa en Potosí que monta todo mas de quatrocientos $y$ beinte $y$ seis pesos $y$ todo eso dan $\alpha$ un solo indio $y$ tienen a gran dicha $y$ ventura allar quien quiera ir por esta paga y este tal fuera de lo que a recibido gana mas lo que le dan en Potosí.

Conforme a las Ordenanzas de don francisco de Toledo en acabondo estos dos mil y docientos indios su mitta que les dura un año luego que llegan los otros dos mil y docientos que suceden en los mismos trabajos se avian de volver a sus pueblos, pero en esto no se a puesto ningun cuydado ni diligencia y assi sera bien decir que tantos buelben y que tanta ganancia traen de tanta riqueza que llevaron y de lo que en Potosí an ganado.

Averiguadamente se sabe $y$ no por via de sospecha $y$ duda que no buelven quinientos indios $y$ que todo el resto con sus mugeres y hijos que seran cinco mil almas unos se quedan en Potosí y otros se van a los valles que ay a la una $y$ otra parte. La razon que a esto les muebe es que quando quieren volver como la ausencia es de tanto tiempo $\mathrm{y}$ de tanta distancia no tienen chacaras sembradas en sus pueblos y muchos o todos no tienen ganado y assi no tienen de que sustentarse quando quieran volverse. Lo segundo saben que en volbiendo los an de occupar en trajinar $y$ en el servicio de los tambos y como de algunos años aca van faltando indios en mas cuontia que de antes y el numero de los españoles crece y cargan estos rabajos sobre los pocos que ay $y$ buelven de Potosi, quitanse de ruido Y quédanse donde mejor les parece.

Lo tercero, como ay tan pocos indios desde algunos años aca y particularmente en estos ultimos acontece y es muy ordinario que en llegando el indio de Potosí a su pueblo como su cacique esta apurado y no tiene indios con que cumplir el numero que le cabe y el gobernador y Jueces le apremian a que le entere tornale a nombrar para que tome otra vez a Potosí con las mismas obligaciones y cargas arriba referidas que quiebra el corazon ver sus lloros $y$ tristeza $y$ destos suelen aorcarse artos $y$ assi por escusarse destos trabajos se quedan o huyen adonde esten libres dellos.

Lo quarto tienen un gran probecho en huirse $\alpha$ los valles $y$ es que tienen que comer y se libran de todas estas vejaciones, y los que se quedan en Potosi acabada ya su mita y año no los fuerzan a que trabajen en las minas por obligacion sino que ellos de su vella gracia se alquilan y ganan dos tanto $y$ tres tanto que los indios de cédula y no los azotan ni castigan como a los otros ni tampoco pagan al rey los treinta pesos de tasa $y$ estan desobligados como esta dicho del trajin y tambo y de otros trabajos que pa. decen en sus pueblos y muchos mineros ganan mas con estos que assi se alquilan que con los de cédula como despues se dira. Estos indios que asi se quedan son los que de ordinario quedan amancebados como se dijo más arriba y particularmente los que quedan en Potosi como estan mezclados con indios de tantas naciones, dánse a vicios y borracheras con grandissimo exceso, y todo esto se permite y consiente para que aya mas gente para las minas y como tienen ya la renta cierta que es alquilarse y ganar mucho mas que los que acuden de obligacion por que cada mes les sale a 40 
ps. de ganancia y ven que son bien tratados de los mineros, no quieren otro Dios ni otra habitación $Y$ tienen tambien otras granjerías que pueden acudir a ellas por ser libres. El daño que reciben en sus almas no solamen. te estos pero cun los que estan mas de un año es muy grande $y$ en particular lo an advertido los padres de la Compañía que estan en la Dotrina de Juli que assisten con más continuacion en el pueblo que los clérigos de los otros por trocallos y mudallos sus perlados mas a menudo $y$ saber los unos de los otros con tanta puntualidad el estado de sus dotrinas y es que quando buelve un indio con su muger y hijos no saben mas de la dotrina christiana que si nunca la ubieran aprendido y bienen tan estragados en sus costumbres que es menester tornar de nuebo en todo y si les preguntan ca mo no saben nada de lo que avian aprendido no dan otra respuesta mas que decir que an ido a Potosí.

Dicen algunos y bien baquianos que el dia de oy abró en Potosí camo seis mil indios con sus mugeres y hijos de sola la provincia de Chucuyin $y$ aunque estan tan apartados della tienese por cierto que sus caciques cckran dellos la tasa muy por entero, y cunque no paguen al rey los treinta pesos pagan y dan a ellos a mas de quarenta y cun de sesenta y la misma cantidad cobran de los que topan en los valles que tambien se tiene por muy averigoado que de muchos dellos saben donde estan aunque no de todos. La platica que a estos indios les hacen es decilles que ellos no acuden al servicio del tambo ni al trajin ni a la labor de las minas de Pa tosi $y$ que an alquilado $\alpha$ otros indios por ellos que estaban obligados $a$ hacer todo esto y que assi an de pagar lo que en esto se a gastado $y$ a veces no a sido un solo real todo el gasto que refieren. Si se quedan o no los caciques con estas ganancias y otras semejantes requería una relacion de por si $y$, lo que se sabe de cierto es que ay muchos rezagos en la hazienda real $\mathrm{y}$ en conclusión tienen los indios por bien de dar la cantidad dicha por verse libres de los trabajos y grandes perdidas que padecen los que estan en sus pueblos.

De todo el ganado que llevaron que pasa de treinta mil cabecas no buelven mil ni aun quinientos y los indios que buelven vienen tan pobres $y$ desnudos que es lástima vellos pidiendo limosna de puerta en puerta y a los pasajeros $y$ el marido trae un niño a cuestas y la muger otro, y la regla general que ay para conocer $\alpha$ uno de estos de donde venga sin preguntario es vellos tan pobres y desnudos y con la lastima y lágrimas y reverencias que piden limosna para poder llegar a sus pueblos. y si algun in. dio trae alguna platilla no es de los que an trabajado sino de los que mandan.

Pondérese pues, aunque brevemente, que cada indio destos dos mil y doscientos a pagado al rey en un año treinta pesos de tasa y que muchos mineros an sacado de las minas mucha cantidad de plata y an enrriquecido con su trabajo y que desta ganancia an resultado muchos quintos a Su Magestad y que muchas personas a quien se a hecho merced de diez o beinte indios de cédula cada indio le a valido por un año cien pesos ensayados y que los tristes llevaron de su hacienda mas de trecientos y beinte mil pesos de caudal y que todo esto lo an consumido para poderse sustentar $y$ vestir y pagar la tasa y que buelven sin un real ni marabedi y que los que se huyen a lcs valles o se quedan en Potosí se allan sin nada y en conclusion a todos enrriquecen y ellos quedan de la manera dicha. Algunos caciques dejan de embiar a Potosí a muchos indios que les cabía el ir conforme a la reparticion que tiene hecha por los cohechos que reciben como 
es docientos y trecientos pesos en plata o cosas que lo valgan y otras voces nombran al que no avia de ir por rrecibir otro tanto.

\section{Capítulo segundo en que se trata lo que es el trajin y los agravios $y$ daños que del resultan a los indios.}

Siguese agora tratar de lo que es el trajin para que mejor se entienda la zazon que los indios tienen para no volver $\alpha$ sus pueblos, porque $\alpha$ la ho. ra que llegan luego los mandan acudan estos y en lugar de descansar por los trabajos que an tenido en Potosí hácenlos trabajar de nuebo teniendo tambien en esto muchas perdidas.

El trajin es en esta manera: el Corregidor de una provincia manda a los caciques de su distrito le den cien indios para que bayan con su ganado dei mismo corregidor a Paucartambo por coca, $\alpha$ los valles de Arequipa por vino y unas veces compra él mismo la coca ó vino para cargallo en su ganacio, otras veces la coca ó vino es de otro y él, por la paga que le dan con los indios y ganado que tiene se obliga á ponello en Potosí que es lo que dicen fletar coca o vino y tambien dan los corregidores muchos mandamientos a diferentes soldados y amigos para que los caciques de su juridicion les den los indios que el manda y señala. La paga que dan a cada indio por un mes son cinco pesos de a ocho reales, sacados ya los indios reciben el ganado por quenta y van con el hasta el pueblo donde an de cargar de coca o vino y despues buelven hasta sus pueblos de donde salieron y alli se truecan $y$ van otros hasta Potosi $y$ con todo este viaje de ordinario $y$ a veces mas se tardan seis y siete meses y adviertase que a los que truecan para ir a Potosí con el ganado y carga no les pagan lo que tardan en bolver de Potosí a sus pueblos, y de algunos dias aca por ser tan pocos los indios que ay no se truecan sino que unos mismos hacen el biaje entero.

Este trato tiene tambien algunos cargos de consciencia y casi le temen y aborrecen tanto los indios como el ir a Potosí. Lo $1^{\circ}$ la paga de cinco pesos cada mes es poquissima, porque cada indio come en un mes lo mismo que se dijo en Potosí, salvo que los precios son mas moderados y para que mejor se entienda esto se referira brevemente lo que gastan., El chuño $\mathrm{y}$ maiz a valido $\mathrm{y}$ vale de algunos años aca tasandolo al precio más barato a catorce pesos la hanega aunque lo mas del año vale a mas el chuño que es lo que ordinariamente comen pues quéntese de media hanega siete pesos que bien la come en un mes. Iten come tambien un paco o alpaca hecho charqui o cecina que vale lo ordinario tres pesos. Tambien lleba harina de quinoa y aji $\mathrm{y}$ pescado seco para los viernes que moderandolo lo possible vale por lo menos lo que come cada mes tres pesos y medio. Iten gasta cada mes un peso de coca y aun mas, de manera que en solo comer gasta en un mes catorce pesos y medio y los que desto tienen mas larga experiencia dicen llega a mas y no se quentan los vestidos que rompen y las ollas que llevan para guisar su comida y otras cosillas ni la tasa que pagan.

Lo $2^{\circ}$ les hacen aderezar las isangas en que llevan el vino, o los cestos de coca y hacer sogas de hichu y por estas cosas no les pagan nada.

Lo $3^{\circ}$ cada indio destos lleva dos carneras suyos en que carga su comida $y$ un chuse en que dormir $y$ una estera con que cubrirse de noche $Y$ defenderse del frio y del agua porque siempre duermen en el campo.

Lo $4^{\circ}$ el que trajina obliga a estos indios que den por entero todas las boiijas de vino o los cestos de coca que les entregaron juntamente con el gancdo, de manera que si falta algunos desto y no ay clara y manifiesta escusa de que si falto alguno fue sin culpa suya lo an de pagar por entero. 
No se niega que algunas veces los indios hurtan algo particularmente quando les parece que no se sabra; pero es muy ordinario como ban tantos carneros juntos cutir las unas botijas con las otras y quebrarse sin culpa de los indios y otras veces en los mismos caminos por aver en las laderas algunas piedras muy salidas donde topan las botijas, y atras en los pueblos por donde pasan en las esquinas de las calles, y otras acontece y muy a menudo espantarse el carnero de qualquier cosa y dar un brinco y al primero cia con las botijas en el suelo y si ay algun camero al lada ayuda a que se quiebren mas y quando dan estas escusas los indios por maravilla son creydos y assi les hacen pagar las botijas que faltan, no a como costaron donde se compraron sino al precio mas riguroso de a como valen en el pueblo donde hechan de ver que se an quebrado y de creer es que si a de pagar un pobre indio ocho pesos o nuebe por una botija, que no querrá quebralla y bebslla por no desembolsar tanta plata.

Lo $5^{\circ}$ del ganado que se les entregó para chacanear si se huyó alguno como acontece de noche quando pasa alguna zorra por junto a ellos se alejan tanto que quando a la mañana quieren cargar estan tan apartados algunos que ni scben dellos ni adonde ir a buscallos o si acaso an hurtado otros indios algun ganado de noche, que se sabe se suele hacer esto muy de ordinario, si los pobres que trajinan no dan alguna señal de que murió de cansado o biejo o de enfermedad se lo hacen pagar por entero y siempre el carnero muerto o perdido dice el español cuyo era que era el mejor de la manada y que se le hurtaron para padre y hacer casta y asi le vienen a pagar por cada uno $10 \mathrm{ps}$. Y puédese creer no le bastara porque enire si mismos hallan carneros tan buenos y mejores y por menos plato. Verdad es que ay algunos españoles, aunque pocos, que no llevan esto por el punto crudo sino con más conveniencia y christiandad.

Lo $6^{\circ}$ reciben estos indios gran daño en su propio ganado y dejan en sus pastos porque en biendo que el dueño esta ausente lo hurtan y no temen a la nuger ni hijos y ay de esto mucha experiencia. Iten para que este ganado se aumente se requiere mucha asistencia de los mismos indios y esto cesa con su ordinaria ausencia, Iten parte dello se huye.

Lo $7^{\circ}$ le reciben en sus chácaras porque la muger puede muy poco, y tiene bien que mirar por sus hijos y casa y acudir a hilar y hacer ropa.

Lo $8^{\circ}$ le reciben en sus almas que como se ausentan tres $y$ quatro meses $y$ a veces mas, como es quando van a Paucartambo por coca y estas ausencias son tan ordinarias olvidaseles lo que saben de nuestra fe y en los caminos cometen muchos y muy graves pecados, de los quales dejarian de cometer gran parte dellos si estuviesen en sus casos y con sus mujeres; cometen tambien muchas idolatrías como gente apurada y olvidada de Dios que ni ve misa ni oye sermon ni ay quien les diga cosa de Nuestro Señor y sus mismas mugeres por la ausencia de sus maridos y por la necesidad que padecen cometen también muchos pecados y ay grandes offensas contra Nuestro Señor y las mas destas cosas se escusarían dando traza que los indios estubiesen mas de asiento en sus pueblos que para todo se puede dar remedio y el estado de matrimonio que es remedio de flacos para no pecar y poderse salvar con mas seguridad ayuda muy poco a estos miserables por la ordinaria y violenta ausencia de sus casas y si con los esclabos casados para podellos apartar de sus mugeres ponen los dotores tantas limitaciones quanta más razon era se tubiera attencion a que esta gente es libre, aunque en el hecho todos son cautivos y mas esclavos que los negros comprados y traydos de Guinea. 
Lo g9 recíbese un grande agravio en toda la comunidad destos indios $y$ un daño no pequeño para todos de tantas ausencias como hacen $y$ es ir a menos esta gente $y$ ir faltando la generacion de los mismos indios por la mucha y ordinaria ausencia que hacen de sus casas y mugeres. lo qual se a hechado de ver notablemente en los niños que se bautizan que son mucho mas de la mitad menos de lo que solia aver pocos años ha.

Algunos corregidores usan en sus trajines de una cosa de gran perjuycio (sic) para los indios $y$ es tomar de su distrito ochocienios y mil carneros alquilados $y$ for tiempo de quatro meses $y$ a veces por mas no pagan sino un peso corriente por el flete de cada uno teniendo obligacion a pagar siquiera cinco pesos $y$ en especial an tenido este trato algunos corregidores de los Pacaxes y Carangas y de Paria y de Chayanta, $y$ en los mismos puestow fletaban algunos españoles en el tiempo que hacian lo referido los corregidores su ganado a razon de a mas de cinco pesos cada carnero y allende de la poca paga que dan por el flete de cada camero muchas veces no pagan cosa a los indios que llevan $y$ trajinan el ganado, que es un robo grandissimo y de extraordinario daño para los indios porque se les muere mucho ganado y no se lo pagan y los indios tienen las mismas pérdidas en sus almas $y$ hacienda que los demas arriba referidos.

De todo lo qual se infiere bien claramente que del trajin salen los in. dios estragados en sus almas, y muchos dellos se mueren en los campos sin confession como bestias, salen tambien destruydos en sus haciendas y dejado aparte el daño que reciben en sus chacaras y ganado lo que gastan cada mes en solo comer son quatorce pesos $y$ medio $y$ mas lo que visten $y$ otras cosillas y lo que consumen en enterar y pagar las averias de la manera que se a referido, de suerte que en trece meses de ausencia buelven los trisies con mucha pérdida, unas veces más $y$ otras menos, conforme a lo que a faltado de lo que trayan a su cargo y casi siempre pasan de cinquenta pesos los que an gastado de más, y assi an dicho muchos indios que temen más el trajin que ir a Potosí, lo uno por ser tan ordinario y con tantas pérdidas suyas y ocasion de tantos pecados. Lo otro porque el ir a Potosí, guardándose con rigor lo que $D$. Francisco de Toledo mandó es 3 ó 4 veces toda la vida. Pero como en lo uno y en lo otro ay tanto exceso todo bo temen como la muerte.

Ay otra causa para que el trajin sea de maior carga para los indios y para que se ausenten de sus pueblos, y es que los españoles van cada dia a mas como se a dicho y los indios a menos y lo que avian de hacer mil lo hacen ciento $y$ aun menos, $y$ esto con los doños y perdidas que arriba se dijo. Y razon era que quando alguinos buelven de Potosi descansaran algunos dias, pero las ansias que los corregidores que de nuebo bienen traen son adquirir plata y mas plata, y pareceles an estado los indios descansando asta su venida y esperandolos para servillos y enrriquecellos, y assi en llegando luego apremian a los caciques de su distrito a que les den indios y carneros para trajinar y les mandan hacer ropa y otras cosas y como se van mudando los correjidores van avibando los deseos $\mathrm{y}$ aumentándose los trabajos de los tristes indios y a todos les parece que el dia que no trabajan para su provecho que huelgan y pierden tiempo, como si no tubieran arto que hacer en sus pueblos $y$ no ay nadie que tenga atencion $\alpha$ los muchos trabajos que an tenido y los corregidores que de nuebo bienen cada uno trae un escribano y un algoacil $y$ un teniente $y$ a veces mas de dos $y$ de quatro $\mathrm{y}$ algunos amigos con otros que se allegan con dádivas $\mathrm{y}$ presentes $\mathrm{y}$ mil generos de lisonjas sin otros muchos que de su parte buscan indios con cohechos $y$ de la manera que pueden. 
A todo esto se añade que fuera de los indios que los corregidores toman para si y los que dan a sus officiales y amigos y a otras personas algunos Virreyes an dado provisiones a muchos para sacar cantidad de indios por los servicios $y$ meritos que representan y por las relaciones que dan $y$ de creer es que si supieran el exceso que en esto ay pusieran mas los ojos en el remedio y satisficieran a estas personas benemeritas sin daño y perjuicio de los indios, y de la audiencia de Chuquisaca tambien hacen peticiones y cartas que son bien efficaces para que se den indios $y$ assi no allan remedio en parte ninguna.

$$
\text { * * * }
$$

Capitulo III.-Del modo y manera con que los corregidores $y$ otras personas tratan en ropa de la tierra $y$ del agravio que en esto reciben $\mathrm{Su}$ Morgestad $\mathrm{Y}$ los indios.

Reciben los indios otro agravio de los corregidores que es el hacerles ropa de la tierra la qual reparten en todos los pueblos de su distrito y algunos con tanta demasia y rigor como luego se dira. Este trato tiene tambien sus cargos de conciencia.

Lo 19 La paga que se da por cada pieza que es manta y camiseta es muy poca que son tres pesos y medio de a ocho reales y para averiguar ser esto assi de proposito hizo la experiencia de lo que cuesta un Retor de la Compañía de Jesús de Juli, y suponese que por cada dia que se hila o teje se paga un solo rreal que assi lo mando decir a un Visitador general en la provincia de Chucuyto. Verdad es que entre los mismos indios se paga a mas porque a una india fuera del real que les dan por su trabajo por un dia les dan tambien de comer. este Retor busco muchos reales sencillos y dioles $\alpha$ dos fiscales $\alpha$ los quales mando con mucho rigor hiciesen hilar $y$ tejer a dos indias todo el dia y a la noche pagasen lo que el Visitador avia mandado que era un real a cada una, los fiscales. lo hicieron assi y entrambos eran hombres de bien y ricos $y$ que en cosa tan poca no buscarían su interes y particularmente por el deseo que tenian de dar contento al Rector y quando vino a acabarse la hechura costó seis pesos y tres reales sin la lana que costó medio peso, de manera que el primer agravio es pagarse casi ia mitad menos del trabajo, verdad es que los mismos indios suelen vender la ropa en las partes a donde se hace casi al mismo precio que costó la dicha hechura o poco mas.

El $2^{\circ}$ es que con pagarse tan poco esa cantidad no se da a las personas que an trabajado sino a los Caciques, los cuales casi siempre se quedan con la plata. Porque ordinariamente una pieza de ropa la vienen a acabar 6 ó 8 indias y es que la una hila la mitad y la otra la otra mitad y otra la pone en el telar y otra teje un pedazo $y$ otra otro pedazo, porque como tienen chácaras y ganado $y$ servicio de tambo $y$ otras cosas $a$ que acudir $y$ esto tan a la continua por marabilla se hallara que sola una india acabe toda una pieza y de donde nace quitarse de ruydo los caciques en averiguar quanto trabajó la una y quanto la otra para dar a cada una la parte que le cabe de los tres pesos y medio y assi para hacer la quenta mas facil se quedan con todo. De donde se sigue que aunque los correjidores y otras personas que mandan hacer ropa pagaran a ocho y diez pesos por cada pieza no satisfarian a su consciencia pues se ponen a manifiesto peligro de que nunca pagaran a las personas que trabajaron en hacer su ropa, porque por mas que den al cacique pues saben que se queda con ello siempre quedan 
debiendo a la una y otra india su trabajo. $Y$ ay muy larga experiencia $y$ de gente de muy buena consciencia que en este caso a querido descargar la de alguno o algunos correjidores y a sido impossible el hacello por ser dificultosissimo juntar las indias que avian trabajado porque unas estavan en sus estancias de ganado y otras eran idas a Potosí con sus maridos y otras eran muertas $y$ otras se avian huydo a los valles $y$ quando estubieran todas juntas no se pudiera averiguar quantos dias trabajó la una y quantos la otra y como es mucha la ropa que mandon hacer viene a haver una confusion que es impossible disen marañarla. Y por las muchas ocupaciones que estas indias tienen como esta ya dicho es imaginación pensar que sola una a de acabar una pieza entera, y assi quererse poner uno $\alpha$ este riesgo $Y$ obligarse $\alpha$ lo que no podra satisfacer bien se ve encarga su consciencia. Y quando no apuran assi a los indios cada una hace la ropa que puede para si y su marido y sus hijos y tambien para vender, pero los corregidores quieren mas priesa que esta $y$ si unas pueden hilar $y$ tejer otras no pueden pero quando el lo manda todas lo an de hacer.

Lo $3^{\circ}$ Se sigue desto otro daño a Su Magestad y a los mismos indios y es que como los correjidores apremian con tanto rigor a los caciques $\alpha$ que hagan esta ropa acontece y muy muchas veces que la que toda la comunidad de los indios tiene hecha para pagar su tasa al Rey la toma el corregidor para si $y$ dice $\alpha$ los caciques que la que avian de hacer para el la mandan hacer para Su Magestad, de donde se sigue que como estan tan alcanzados de tiempo assi los indios como las indias y cada dia van a menos y no tienen tiempo burlando ni de veras por sus muchas ocupaciones para hacella otra vez y pagalla $\alpha$ Su Magestad aya muchos rezagos, y lo que las indias trabajaron para pagar esta tasa de que no recibieron paga ninguna lo tornan a lastar y con la misma paga referida y como quiera que sucedan las cosas carga sobre los indios $y$ an de enterar lo que no pueden y ansi paganlo otra vez. Pocos años a que se vio en la provincia de Chucuyto por estos excessos dever a Su Magestad trece mil piezas rezagadas lo quál no ubiera avido sino se ubiera mandado hacer tanta ropa a las indias.

Fuera de los casos que no se pueden decir se referirán dos que acontecieron en la dicha provincia por el rigor con que mandaban hacer la ropa los correjidores, el uno es que $\alpha$ una india que tenía dos hijos que mamaban la daban tanta prissa su cacique y principales con amenazas y azotes para que hiziese una pieza de ropa del corregidor por la prisa que el daba para que se acabase la que avia repartido, que viendose aflijida y tan alcanzada de tiempo que aun no le tenía para sustentar $y$ dar el pecho $\alpha$ sus niños los mató por no vellos llorar tanto ni entristecerse viendo que se le morian poco a poco. En otro pueblo siendo tan perseguida otra india de su cacique como la que se a dicho y por la misma razon se arrcaron ella y sus hijos, $y$ en fin luce todo como ganado $y$ adquirido por tan buenos medios.

$$
* * 2
$$

Capítulo IV.-De la manera que algunos corregidores y otras muchas personas se conciertan con los indios, para que les den el servicio ordinario por un año $y$ el grande agravio que en esto reciben.

Algunos corregidores y otras muchas personas que son hartas hacen un concierto con los hylacatas y Marcacamayos que son los mandones que ay entre los indios para que en lo que toca al servicio ordinario de su casa 
acudan con lo que ellos usan dar, y assi se obligan los indios por la paga que reciben a dalles mitayos para la cocina y para la sala que es el guarda platos y para la caballeriza y tambien para guardar unas cabras y traelles agua y leña para la cocina y orno y para calentarse y la hierva necessaria para sus cabalgaduras $y$ dos reales de huebos y dos de pescado para tocios los viernes y sabados y dias de ayuno de todo el año y manteca de puerco para guisar el pescado y huebos y otros potajes y tambien traen la sai y aji y ollas que son menester y conciertanse de ordinario por tan poco que es verguenza referillo. Pornanse aqui dos casos no porque sean raros sino los muy ordinarios para que mejor se entienda el agravio que en esto ay. Un Juez se concerto con los hylacatas y Marcacamayos para que le diesen el servicio ordinario ya referido por tiempo de un año y dioles para mas descargo de su consciencia treinta y cinco pesos de a ocho reales dijo que no queria reparar en pocas cosas y que las dava cino pesos mas que venian a ser quarenta. Despues el dicho Juez trato lo que avia hecho con un cierto religioso y le dijo que por quitarse de escrupulos les avia dado cinco pesos mas de lo que se avian concertado, el dicho religioso que sabia bien lo que eran estas cosas disimulando por entonces con el Juez tomo tinta y pluma y fue sumando lo que montaba todo lo que los indios le daban apreciando las cosas con la moderacion possible las quales eran las siguientes.

Frimeramente le daban quatro mitayos cada dia que pagando a medio real caca uno sin dalles de comer que no se lo daba son dos reales cada dia y al cabo del año setecientos y treinta. Davanle mas dos reales de hucbos Y clos de pescado todos los viernes y sábados y dias de ayuno de todo el año que contandolo algo escasamente montan quinientos y sesenta reales. Mas le daban tres cargas de leña cada dia y fuera desto dos veces en la semana quatro para cocer pan que venian a ser cada semana beynte y nuebe que a medio real cada una valian cada semana catorce reales y medio que multiplicado por cinquenta y dos que tiene un año son setecientos y cinquenta y quatro reales. Mas le daban manteca todos estos dias de pescado que la cantidad valia mas de un real que en todo un año moderandolo lo possible bienen a ser ciento y quarenta reales. Trayanle tambien todos los dias ollas y cazuelas y sal y aji que por lo menos lo uno con lo otro montaria cada dia un cuartillo particularmente por quebrarse ordinariamente las ollas y cazuelas, monta todo esto en un año noventa reales. Mas se occupaba una india o un indio en vendelles el pan que hacia y quando no allaba el triste indio quien se lo comprase le obligaba lo tomase para si pues no avia sido para vendelle y que le diese en plata lo que el pan valía a este indio le cabria por lo menos un cuartillo cada dia y porque no todos los dias vendia pan se le quentan quarenta reales por un año que sumada toda la partida montan dos mil y trecientos y catorce reales y reducidos a pesos de a ocho reales ron docientos y ochenta y nuebe pesos y dos reales y no se quenta la hierva que le daban porque el dicho religioso no supo de cierto qué tanta era.

En otra parte se concertó otra cierta persona con los Hilacatas y Marcacamayos del pueblo donde vivia por otros quarenta pesos comientes, pero dábonle fuera de lo dicho todos los dias del año un real de belas y seis cargas de hierva que contando cada una a cuartillo, porque habia más de ella en aquel pueblo que en otros, reducido todo $\alpha$ pesos son $117 \mathrm{ps}$. y medio. Mas le daban todos los dias de carne 2 aves que á 3 reales cada una moderando los dias y el precio montan 150 ps. y lo que se avia de pagar a algunos indios que se ocupaban en guardar su ganado. $Y$ adviértase que assi el Juez como a esta otra persona daban muy de ordinario mas pesca- 
do y huebos y manteca de lo que se a dicho conforme al numero de jos husspedes que tenian que particularmente el uno tenia muchos $Y$ esto no se quenta, monta pues todo lo que daban a esta persona quinientos y cinquenta $y$ seis pesos y seis reales.

Estos dos exemplos se an puesto para que por ellos, como se dijo al principio, se sepa con la buena consciencia que se hacen estos conciertos y el grande engaño que ay en ellos y el agravio que los indios reciben. Adviertase que muchos caciques son servidos de la misma manera que los dos sobredichos recibiendo de sus indios las mismas cosas referidas y para ajustar sus quentas mas a su placer y con menos quebradero de cabeza no pagan cosa. Tambien se advierta que con ser tan moderada la cantidad que pagan algunos con todo eso nunca llega a manos de los pobres indios particulares que trayan leña y hierva y huebos y pescado y las demas cosas, sino que se quedan con ella los mandones $y$ principales, como se dijo en lo de la ropa y por la misma razon aunque dieran mil pesos a estos mandones no satisfarian a su consciencia, pues se sabe de cierto que esta cantidad que pagan y dan a los mandones nunca la reciben los indios que dieron y trajeron las cosas dichas y sirvieron de mitayos, y quando quisiesen juniallos al cabo del año o mas a menudo seria impossible, porque unos an ido alquilados para el trajin y otros estan ya en las minas de Potosí $y$ otros an ido a buscar comida $\mathrm{Y}$ otros estan en sus estancias y assi es impossible pagar a las mismas personas que se deve dilatando la paga por tanto tiempo.

$$
\text { * * * }
$$

Capítulo V.-De los agravios que muchos corregidores hacen a los indios de sus repartimientos vendiendoles algunas cosas a mucho mas de lo (que) valen forzandolos a que las compren.

Otro agravio -reciben los indios de los corregidores y es que mandan con mucho rigor que nadie trayga a vender a su repartimiento aquellas cosas de que en el ay falta, y luego ellos las hacen traer y las venden como queren $y$ entre otras cosas suele ser muy ordinariamente el vino el qual traydo a su distrito le ponen precio como es a diez y doce pesos y a mas la botija no valiendo a ocho. Traydo el vino unas veces le reparten por ayllos o parcialidades de los indios, otras veces lo ponen en una tienda, $y$ como en todo el repartimiento no ay otro vino $y$ es excessivo el precio que ellos an puesto vendese como quieren. Verdad es que esto ultimo se hace pocas veces. Muchas veces no quieren recibir plata sino otras cosas que ay en el distrito como es chuño, o maiz, o carneros o otras cosas que ay entre los indios. Un corregidor repartio mucho vino en su distrito contra la voluntad de los indios y a pesar dello mandó que por cada botija le diesen dos carneics rasos escojidos de la tieria que valian mas de dos tanto que el vino y era grandissima lastima ver los llantos y lloros de los indios con. siderando que les hacian tomar el vino por fuerza y que les quitaban sus carneros sin poder resistir a esta violencia y que por una botija que valía de siete $\alpha$ ocho pesos pagaban beinte en dos carneros escojidos que daban por cada uno. Otro daba cada botija por cierta cantidad de maiz el qual recibia al tiempo de la cosecha a muy menor precio de a como se vendía por entonces y venía a cobrar de cada indio mas de a dos tanto de lo que el vino valía, y tienen en esto tanto rigor y aspereza que los pobres indios 
se dejan robar por no verse tan maltratados y azotados y metidos en las córceles que para esto todos tienen vara real. Muchas veces acontece, como sucedió poco ha, que llevaba un soldado una partida de vino a Potosí y pasando por donde havia puesto un corregidor estanco, de que en su partida no pudiese vender nadie vino, por poder mejor vender él el suyo, temiendo el soldado la pena que habia puesta habló al cacique para que le comprase, si gustaba dello, cinquenta botijas para si o sus indios y que se las daría a como andaban que era $\alpha$ siete pesos. el cacique fue a tratallo con la persona que vendia el vino del corregidor $y$ dijole que el ni sus indios no tenían necessidad de vino porque gastaban en eso la plata con que pagaban la tasa, pero pues que era fuerza y los apremiaban a comprallo contra su voluntad que comprarian el que un pasajero les vendia que era muy bueno y a como valia de presente que era $\alpha$ siete pesos y que no los apremiasen a tomar el del corregidor $\alpha$ once pesos que era el precio que el avia puesto. La respuesta fue decille que era un vellaco y que si le hablaba mas sobre esto le daria una buelta de coces muy bien dada y que no se avia de comprar otro vino sino el del señor corregidor $y$ al precio que el tenia puesto.

En vender vino entre los indios ay muchos daños y entre ellos el primero es que por poco que bevan se enborrachan sin remedio y desto ay muy larga experiencia $y$ assi sucedio a un religioso una vez que queriendo regalar a nuebe indios cantores les dio a beber un poco de vino y temiendo no se emborrachasen, el por su propia mano dio a cada uno una vez de vino no mas en una escudilla vidriada $y$ el vino se le dio aguado, y assi de suyo no es lícito vender cosa que tan facilmente priva el juicio de donde nacen grandissimos pecados y aunque también se emborrachan con chicha pero exto es bebiendo mucha cantidad della que por lo menos a de ser diez tanta cantidad que la que les emborracha de vino. Lo $2^{\circ}$ gastan los pobres indios la plata o comida o ganado que tienen en pagar el vino y muchas veces acontece tomalles sus vestidos y pobres alajas $y$ venderselo todo para cobrar el corregidor su plata. De donde resulta lo tercero que al tiempo de pagar la tasa no tienen con que por aver gastado lo que tenian en pagar el vino. De donde se sigue lo quarto que como apuran $\alpha$ los indios $\alpha$ que enteren su tasa y no pueden se huyen y deja de cobrar el rey sus rentas reales y los correjidores an cobrado muy bien sus deudas, y estas cosas y otras semejantes las saben callar muy bien y los indios an de ser culpados en todo y como los corregidores que suceden $\alpha$ los pasados lo ordinario van por el mismo camino no saben que hacerse ni a quien quejarse $y$ bien se ve la mucha cantidad de plata que por este trato tan malo estan obligados a restituir $y$ por otros que se an dicho $y$ dirán.

$$
\text { * * * }
$$

\section{Capítulo VI.-De las tasas que suelen tomar los corregidores para sí $Y$ del daño que desto recibe la hacienda real $Y$ la de los indios.:}

Reciben otro agravio los indios de los corregidores no pequeño como es, quando en un pueblo de su distrito pagan ciento o docientas hanegas de maiz para el encomendero o para el Rey y supóngase que es para el Rey que es donde mejor se executa su intento. Al tiempo de cobrar esta tasa $y$ enterar las Cajas vendese por pregones el dicho maiz $y$ el corregidor hecha uno que saque para si esta tasa $y$ esto con cierto silencio y traza que 
quando venga a tomalle residencia se halle por escrito que no fuese el que sacó para si la tasa: y por otra parte usan de su acostumbrada maña y es que se sepa que aquel maiz es para si $y$ con esto no ay nadie que se atreba a pujar y assi sucedió agora que remataron cien hanegas a seis pesos y enteraron la caja con seiscientos pesos, y valía el maiz donde esto sucedio a once y a doze pesos, y porque los indios no tenían maiz ni aun para comer cobrabalo el corregidor $\alpha$ once $y$ doce pesos $y$ esto con tanto rigor $y$ crueldad que los pobres indios vendian sus carneros $y$ vestidos pora podelle pagar y contentalle, y despues por hacelles mejor obra mandó que la paga no fuese en plata sino en otro género de comida que a cada hanega de maiz correspondian 14 pesos y eso mismo hizo en otros pueblos de su distrito y casi no hay Corregidor que no lo haga haviendo ocasión para ello a como anda y vale y no a como ellos estan obligados a pagalla que lo oräinario es menos de la mitad, y como esto se hace en tantas partes $y$ con tanta continuación es una carga pesadissima para los pobres indios $y$ de grandissimo cargo de consciencia y que ay arto que restituir. Otros ay que por el contrario quando ay buen año hacen que se junte el maiz o chuño y estando la cosa presente mondan que se venda por pregones $y$ en conclusion sacan la tasa para si de la misma manera y con las mismas circunstancias ya dichas y si al hanega vale ocho pesos se vende a quatro y en cien hanegas de tasa es defraudada la hacienda real en quatrocientos pesos y otras veces con mucho mas. Y quando se venden quinientos 0 seiscientos carneros de Su Magestad que por lo menos valen a nuebe pesos como se sabe ya que el corregidor a hechado uno que los saque para si y los que estan $\alpha$ la mira $y$ oyen los pregones le an menester para sus granjerías nadie se atrebe a pujar un solo real y assi bienen a rematorse a cinco pesos o a cinco y medio y si no ubiera estas invenciones se vendieran por lo que valen $y$ assi biene a ser defraudado Su Magestad en mucha cantidad de plata $Y$ como estas cosas se hacen en muchas partes $y$ muy a menudo viene a ser mucha la cuantía, de manera que en buen romance o an de hurtar a Su Magestad o a los indios.

En algunas partes se vende la tasa que los indios de un pueblo o de muchos an de pagar al Rey assi de carneros de la tierra como de ropa y maiz sin que lo uno ni lo otro este cobrado ni presente y esta venta se hace por voz de pregonero como las demas dichas y adviertase que los indios no estan obligados a dar y pagar los cameros sino de dos años y medio y assi se rematan en los pregones como nuebos y de poco precio que no lo son de tanto como los $y^{\alpha}$ hechos, las personas con quien se remataron que de ordinario son los corregidores o otras como ellos cobran los de los indios de tres $y$ quatro años y muy escojidos $y$ de manera que en cantidad de docientos carneros hurtan a los indios mas de ochocientos pesos. Lo mismo se hace en la ropa de la tierra la qual tampoco están obligados los indios a dalla escojida y buena sino la que llaman de tasa que es muy ordinaria que parece que en todo favorece el Rey a los indios no obligandolos sino a lo que muy commodamente puede hacer. Esta ropa sin estar presente ni comenzada $\alpha$ hacer anda en pregones $\alpha$ quien mas diere por ella y como dice el pregonero que es de tasa remátase también en muy poco precio y tambien la suele sacar el corregidor o otro que pueda tanto como el, pero de ordinario es el corregidor. Despues al tiempo del cobralla no la quiere conforme $\alpha$ como los indios estan obligados a dalla y pagalla al Rey sino que la mandan hacer muy escojida con muchas colores y en cien piezas de ropa por lo menos hurtan mas de quinientos pesos $y$ como esto se hace tambien en todos los años y en muchas partes es un robo grandissimo $y$ de extraordina. 
rio daño para los indios por el mucho tiempo que en esto los ocupan. Muchos vecinos ay que no se contentan con la ropa que de obligacion les pagan sus indios sino que se la mandan hacer escojida y muy buena de la manera dicha y en fin por todas partes an de ser perseguidos. Io que algunos hacen es dar los colores de su casa.

Algunas veces usan los corregidores de otro robo mas moderado y es que los indios tienen privilegio $y$ facultad en algunas partes $y$ aun en $m u-$ chas para pagar la ropa a Su Magestad en plata la qual esta tasada a maderado precio y el corregidor apremialos a que esta tasa la paguen en ropa aunque sea de la que llaman de tasa y como no pueden resistir a su poder paganla en ropa y de derecho pues que los indios la pagan en especie todo io que ella vale avia de ser del rey: cobrada pues la ropa enteran la caja a como ella esta tasada por don trancisco de Toledo y vendela $\alpha$ dos tanto de como esta tasada y esa mitad la toman para si.

En cierta parte devian los indios al Rey como mil pesos y no tenian plata para pagallos viendo el correjidor tan buena ocasion dijoles que el les prestaria los mil pesos con condicion que se los pagasen en carneros. Vinieroil los indios en ello por la prissa que les daba a que los pagasen. Concertáronce los carneros a como él quiso y luego hizo demostracion de que metia en las cajas los 100 pesos y no los metió en mucho tiempo. Hecho esto mandó que luego á la hora se cobrasen y fueron algunos oficiales suyos de pueblo en pueblo y juntaban en un corral quantos carneros hallaban y si no les contentaban con amenazas y azotes hacian se trajesen quantos avia y alli escagieron como 200 carneros que valian entre los españoles más de 2,000 y 200 ps. por ser escogidos de la manera dicha y en parte donde los ay muy buenos. a bueltas de los carneros que escogieron de los que devian los 1,000 ps. al rey, como hacian juntar quantos avia, llevaron algunos que eran de indias pobres y viudas que no debían nada. Estas vinieron al Corregidor y rogáronle con grandes lloros y lástimas que les volviesen sus cameros que no tenian otro saudal y estaban ciertas que sus caciques no se los avian de pagar que es ordinario hacerlo assi en casos semejantes: la respuesta fue azotallas muy bien por lo que pedian y las tristes indias se volvieron gimiendo $\mathrm{y}$ dando gritos viendose las pobres sin remedio ninguno que era lastima vello y assi en este caso como en los referidos y en otros muchos que ay se verifica bien a la letra lo del sabio que dice: Vide calumnias quae sub sole geruntur et lacrimas innocentium et neminem consolatorem (Al márgen: Ecle. siastés c.4). Vi dice los agravios que se hacen en el mundo y las lágrimas de los inocentes y que no havia nadie que los consolase. Destas cosas nunca avisan los corregidores a los Virreyes ni de la crueldad con que los ro. ban y de como son causa de que se huyan los indios por lo que con ellos hacen por sus intereses y nótese lo que abra que restituir al rey y a los in dios y como es possible luzca plata tan mal ganada o por mexor decir tan mal hurtada.

\section{Cap. VII. -De como muchas veces so cobra la tasa doblada mas de lo que los indios estón obligados a pagar.}

Ay otra occasion pora que los indios se huyan de sus pueblos y al parecer sin culpa de los corregidores y caciques y es que como esta repartida le tasa de manera que siempre se a de pagar una misma cantidad, el correjidor apremia al cacique a que la de y el cacique como no a de dar de su hacienda un solo real va cobrando de los indios presentes, y porque de 
los indios huydos y ausentes, aunque sabe de buena parte dellos donde eston de todos sea impossible, cobra de los que puede de donde nace que si un indio avia de pagar siete pesos paga beinte y a veces mas y como eso es con daño dellos huyen de adonde se hallen libres destas obligaciones Verdad es que es gran parte para esto los agravios que a la continua reciben como se a dicho. Algunos caciques ay tan astutos y sagaces que por cobrar buen nombre y por que los conserven en su officio cobran de los pocos indios que tienen la tasa entera que deven todos los ausentes y para esto van a otras estancias y les venden sus carneros y hacen otros robos de suerte que pagan la tasa y absueltos hacen su hacienda, aunque lo orainario es aver muchos rezagos.

\section{Cap. VIII.-De los agravios que reciben los indios en guardar ganado de la tierra y de costilla a los españoles y caciques.}

También ay un uso o abuso de grande daño para los indios en toda esta tierra y es hacelles guardar ganado de la tierra y de castilla dandolss muy moderada paga, como es por doscientos o mas carneros de la tierra dailes medio real por cada dia $y$ no mas $y$, según las ordenanzas de don Francisco de Toledo que ay acá arriba que son las leyes deste Reyno, se les avia de dar para más media hanega de chuño o maiz cada mes y la carne necesaria y eso nunca se ha guardado. Solamente pagan 2 ps. por un mes $y$ en algunas partes 2 y medio. Y la razón porque no mándó dơr D. Francisco de Toledo más paga cada mes que los 2 ps: y la carga de comida y la carne necesaria fué por parecelle que los pastores tenian tiem. po para hacer sogas con que podrian ganar alguna plata. De manera que lo que el dia de hoy pagan a un pastor, ora lo sea de ganado de Castilla o de la tierra apenas alcanza para almorzar y sobre ser tan poca la paga obligan al desventurado indio a que entere toda la manada, de manera que si le falta un camero raso a de pagar 10 ps. por él, si no consta muy claramente que murió de biejo o de enfermedad y como se dijo en lo del trajin siempre dice el español o corregidor cuyo era el ganado que aquel carnero que falto era el mejor de la manada. En esto ay dos agravios de grandísimo perjuicio para los indios, el primero es que aun no le pagan bastantemente el trabajo de apacentar el ganado en buenos pastos pues aun no le dan para comer, porque en solo esto gasta en un mes lo que se dixo en el trajin que seran mas de catorce pesos. El segundo es que con ser tan limitada y poca la paga le obligan a que a de asegurar todo el ganado $y$ le a de dar por entero sin que falte nada de la manera que se le entregaron. no son menester letras para juzgar ser este un robo gravissimo y con obligación de restituir muchissima plata y quando les pagaran todo io que gastan en comer no podían obligallos con buena conciencia a que assegurasen todo el ganado, porque todos los teólogos $y$ sumistas (sic) (1) concluyen que por el trabajo se a de dar una paga que en el presente caso es traer el ganado en buenos pastos y por asegurarlo y obligarle $\alpha$ que entere y entregue la manada entera otra paga differente de la passada. y en

(1) Sumistas se toma aquí por moralistas, aludiendo a que la Teología Moral se aprendía entonces en las Sumas de esta ciencia, de las cuales se hizo célebre la del Dr. Navarro (Martín Azpilcueta). 
fin sí clora y manifiestamente no consta como esta dicho de su innocencia y dian señal de que murió el carnero de enfermedad o biejo le an de pagar sin remedio y como se dijo arriba sabese de cierto que ay ladrones que hurtan de noche muchos caimeros y los llevan $\alpha$ vender $\alpha$ otras partes de lo qual ay arta experiencia, $y$ otras veces van tras las obejas $y$ otras se alejan por los leones y es impossible solo un indio guardar tantos aviendo tanias salidas para que desaparezcan y no se atreba el triste indio a dejar toda la manada por buscar un carnero temiendo no le falten mas. Esta vejación que los indios tienen y las pérdidas que desto les recrece es también arta parte para que se huyan a donde no los hallen.

Muchos caciques que an aprendido bien de los españoles todas las cosas sobredichas hacen guardar mucho ganado suyo a los indios con las mesmas obligaciones de enterallo todo y lo ordinario aun con menos paga de la que los españoles dan.

\section{Cap. IX.-Cómo los corregidores salen de ordinario en sus resi- dencias libres $\mathrm{y}$ sin costas con hacer las cosas que se an dicho.}

Con razon podrá dudar quien quiera que ubiere leydo todo lo sobre. dicho como sea possible que en las residencias que dan los corregidores de ordinario dan a tantos por libres y sin costas pues hacen tantas cosas como se an dicho $y$ otras muchas que se an callado $y$ entre ellas muchas fuerzas y adulterios $y$ hacer processos a algunas personas con poca ocasion y llevarles muchos derechos y hacelles muchas costas.

No se niega que $\alpha$ avido algunos Corregidores muy hombres de bien y que aunque an procurado ganar plata $\alpha$ sido sin hacer agravios a los indios $Y$ en este capitulo como en los demas principalmente se $\alpha$ tratado de los corregidores de indios: las razones pues porque de ordinario salen libres son las siguientes. La $1^{\alpha}$ es quando an sacado alguna tasa del Rey de maiz ropa o ganado o de otra qualquier cosa muestran por escrito como se apunto arriba como andubo en pregones y que se remató en la persona que tienen escrita y como no ay a quien le duela el agravio que se hizo al rey y el testimonio que dan vá autorizado con escribano y testigos no se addiciona nada este punto. Lo $2^{\circ}$ quando los corregidores an sacado para si alguna tasa y an cobrado de los indios a dos tanto y a mas de como se remató también dan el mismo descargo y como los indios estan hechos siempre $y$ en todas partes a pagar estas tasas a como valen, en tiempos estériles y que los Corregidores y muchos vecinos siempre ejecutan esto, ninguno dellos pone capítulo alguno, entendiendo que es ya ley que se ha de guardar y que no tiene remedio el pedir justicia y assi era necesario, si fuera possible que un Fiscal del Rey de una de las Audiencias fuera el que en nombre de Su Magestad y de los indios pusiera capítulos a los corregidores que con la entereza que ellos tienen y la confianza de los indios con tan buen protector se satisficieran muchos daños que a la hacienda real y a la de los indios hacen $Y$ quiza fuera acertado que un fiscal destos saliera de quando en quando $y$ publicara que acudiesen a el los indios $y$ españoles para lo que hubiesen que pedir contra los Jueces $y$ otras qualesquier personas que los ubiesen agraviado y que como gastan su salario en la audiencia la gastaran en estas salidas y le señalaran una buena parte de las sentencias y condenaciones. Lo $3^{\circ}$ quando ven los corregidores que biene el tiempo de la residencia luego procuran granjear las personas de quien se temen les por- 
non capítulos, $\alpha$ unos dan indios para travajar, $\alpha$ otros prestan plata y a otros la dan $y$ en fin cierran estos portillos lo mejor que pueden, $y$ a veces a acontecido aver algunos de mas brio y no dejarse llevar destas dadivas y presentes y luego buscan los corregidores un par de soldados de los que llaman valentones y los llevan a su casa y mesa y granjeados por amigos dales algun presente como es a uno una mula a otro una espada $y$ lo ordinario es un golpe de plata y diceles que fulano y zutano le quieren poner capítulos en la residencia que le an de tomar y que son bellacos y mal intencionados y que no a querido desistir de su mal mirando por bien y buenos medios que les ruega den traza como callen: ellos lo hacen y amedrentan de suerte a los que querian pedir justicia que al fin callan de miedo y no a mucho tiempo que sucedió esto en cierta parte. Lo $4^{\circ}$ suelen muchos co rregidores en viniendo su sucesor, que es el que le toma la residencia dalle un muy buen presente $y$ como biene pobre recíbele con ambas manos $y$ hácese la residencia a pedir de boca, quando se teme que el corregidor que biene de nuebo no querra recibir plata entonces acuden a la parte mas flaca que es el escribano y danle un buen golpe della y como este biene pobre recibele y como es el que a de escribir contra él todo lo que pidieren los unos y los otros vá la mano también guiada que no ay que temer la resideicia y como los que suceden vienen a lo mismo y a grangear plata por los mismos medios $y$ de la misma manera que los que an precedido todo parece lícito y hacedero y cissi se da la sentencia como se desea y aunque se ciro al principio que salen sin costas eso es en lo escrito que en el hecho ai las pagas dobladas. Las razones principales pues que todo se fizo noche son Icss dichas.

\section{Cap. X.-En que se trata de los agravios que reciben los in- dios en los tambos.}

Por los muchos trabajos y ocupaciones que los indios tienen se an idn ausentando de manera que estan muchos tambos como se dijo al principio sin servicio por lo qual es mucha la incomodidad que padecen los pasajeros en allar el recado que an menester. y assi ay algunos y muchos que $\in n$ llegando a los pueblos van de casa en casa y a la primer india que topan la llevan que quiera que no quiera al tambo $y$ despues la mandan que traiga lo que han mercado aviendole tomado primero algunas prendas para obligalla $\alpha$ que buelva y coma los indios ban menos y los pasajeros siempre son mas cada dia, ay peor recaudo $y$ muchos yndios se esconden $Y$ huyen de los españoles quando los ven venir al tambo, por las muchas coces y azotes que les dan de antemano $y$ sin ocasion ninguna $y$ temen lo mucho que desto padezen, mientras los sirven $Y$ para que mejor se entienda la rrazon que tienen para excusarse y esconderse, dezirse ha brevemente lo que ordinariamente muchos de los pasajeros hacen. Lo $2^{\circ}$ hay algunos que en llegando al tambo, anie todas cosas dan una vuelta de azotes al Alcalde o Mitayo y luego le piden hierba y leña y huevos y todo el recado que han menester y para que esten cierios que bolverán, tómanles las mantas $y$ sombreros y si alguno les quiere yr a las manos $y$ les ruega que no usen de tanto rigor respóndenle que no conoce $\alpha$ los indios que si no es por mal Y a puros coces y azotes nunca hazen cosa buena. Que bien poco ha que passaron por la Prov. de Chucuito a Potosi dos soldados que hacian esto $Y$ se alavavan de avello hecho ansi en todos los tambos, desde que salieron de Lima $y$ los que esto hazen son muchos $y$ no solamente ellog sino tambien 
sus mismos yanaconas y negros castigan $y$ azotan a los indios con gran crueldad y este género de pasageros son los que de ordinario pagan peor o por mejor dezir dejan de pagar.

Otros ay que en llegando al tambo y en teniendo mitayo que le sirva lo primero que le manda es les traiga una india moza con quien ofenden a Dios $y$ son tantos los que esto hazen, que aunque se diga que de tres partes son las dos no se mentirá. Otros las buscan de casa en casa y para hazer mas a su salvo es que desean aposentarse entre las mismas casas de los indios. Otros se aprovechan de las mugeres de los mismos mitayos a los quales embian por lo uno y por lo otro para tener tiempo para aprovecharse de sus mugeres. Otros ay que se quitan destos embarazos y las traen consigo públicamente de unas partes a otras. Otros ay que para disimular su mal estado las visten en avito de indios y con esto se aseguran de que no se las quitará ningun juez Eclesiástico ni seglar y es tanta la disolucion que hay en este vicio $y$ el mal exemplo que se da a estos yndios que tiene necesidad de un rigurosísimo remedio. Algunos que se ben pobres usan de una maña estraña $y$ es que quando van de un tambo a otro llevan dos o tres apires que asi llaman a los carneros que llevan cargados con su ato y quando llegan a otro tambo comienzan a mirar y rebolver una petaca de las que truxo el yndio en sus carneros $y$ finge que le han hurta. do beynte baras de ruan ( $Y$ luego levantan la boz $y$ echan juramentos $Y$ abion muy reziō y asen del yndio diziendo que es un ladron y que asi son todos quantos ay y que le an hurtado tantas baras de ruan y que no conozen a estos yndios $\mathrm{y}$ al fin encarecen su negocio de manera que le toman tres o quatro carneros y el triste yndio ni save que dezirse ni que hazerse y por mas que diga que no a tomado tal como el pasajero hecha tantos juramentos $y$ aze tantos bisajes no se haze caso del $y$ al fin se buelve con perdida de treynta o quarenta pesos $Y$ con esta buena traza ay algunos que en breves dias grangean buen número de carneros, $y$ asi salen con ello $y$ los yndios quiedan por ladrones sin aver hurtado y aviendoles tomado su ganado. Otros en llegando al tambo piden muchas cossas de las ordinarias como es yerva, leña, pan, guevos y maiz para las cavalgaduras y carne y perdizes y comen muy bien. a la partida que es el tiempo de la paga van pidiendo al mitayo las cossas que le dieron para guardar y después que las a entregado pidenle los zapatos nuevos o borzeguies y el yndio responde la pura verdad que es no aver rezebido tal cosa y luego levantan estos tambien la boz, como se dixo de los otros y juran y dizen que son unos ladrones $y$ que an de pagar los borzeguies nuevos $y$, en fin, por medio de paz váse lo uno por lo otro $y$ quédanse sin pagar y esta misma maña tienen los yanaconas $y$ criados destos españoles o mestizos que porque los mirayos no les dan las cosas que ellos dizen les entregaron les toman sus mantas y sombreros $y$ se van con ello. muchos destos yanaconas $y$ aun de los pasajeros toman destas mantas $y$ sombreros $\alpha$ los Alcaldes $y$ mitayos para obligallos les traigan recado de yerva y leña y de las demas cosas $y$ despues no lo buelven y se van con ello.

Otros ay que por no embarcarse con tantas mantas y sombreros toman a las indias por via de prenda para obligallas a que traigan el recado dicho tres topos de plata, que son unos como punzones largos con una plancha al cabo que cada uno de ellos vale cien reales de los ordinarios $y$ los lleva. Otros ay que en llegando al tambo dan por cuenta algunas cosas al mitayo para que las guarde y luego disimuladamente esconden 2 camisas o 3 de las que entregaron. Despues al tiempo de la partida como faitan las camisas que escondieron hazen grandes ademanes y dizen con 
muchos juramentos al yndio que es un ladron y que le dió 6 camisas contadas y que le a hurtado las 3 dellas $y$ al fin se las hazen pagar sin remedio $y$ esto suelen hazer muy ordinariamente en lo que es espuelas $y$ frenos $y$ asi los yndios en rreciviendo algo desto que es $\alpha$ menudo, van corriendo a sus casas a guardallo, porque aunque no les den espuelas, se las suelen pedir y las más veces se las hacen pagar y asi hay hartos hombres que caminan muchas leguas y atraviesan el Perú sin tener un real, al tiempo que comenzaron su viaje y al fin de la jormada se hallan con harta plata, sobre lo que han comido $\mathrm{y}$ bebido.

Otros ay que piden cavalgaduras alquiladas de un tambo para otro y despues se los llevan y destos ay hartos $y$ en un tambo sucedió que en muy buen tiempo vinieron a tomar los pasajeros a los yndios diez y siete cavallos sin que jamás pudiesen cobrar ninguno. Un otro soldado salió una vez de Lima para Potosí y no llevava un solo peso para el camino pero traya un par de medias de seda $y$ en llegando al tambo despues de aver pedido leña yerva y pan y granos y lo demas que le parezia davalas al mitayo para que se las guardase el mitayo y luego partira con ellas a su cassa porque no se las coxiesen en el tambo por ser ordinario salir cada paso del por yerva y leña y agua y otras cossas que trahen. El español como veya que se yba asia del $y$ deziale que era un perro ladron y que las llevava para quedarse con ellas y mandavale que las colgase y pussiese donde las vie. se. el yndio por el miedo que le tenia lo hazia assi y luego que salia por algo, el español cojia la una media que estava metida en la otra y escondiala en la faltriquera. Despues a la partida pedia sus medias y el yndio como avia visto siempre colgada la media pareziale que estaria metida alli la otra, pero como faltava comenzava a dezir el español con grande enojo y muchas vozes: bien dezia yo que es un ladron este perro yndio y que queria llevarse las medias a su cassa para quedarse con ellas pues delante de mis ojos, me a hurtado la una de ellas por tantos $y$ quantos pesos $y$ que me las a de pagar $y$ despues de mill gritos $y$ amenazas venian a concertarlas en diez o doze pesos $y$ dava a entender que no queria sola una media pero luego dezia que no queria ser cruel con ellos $\mathrm{y}$ que descontase dos pesos de los diez o doze que le dava y que el llevaria aque. lla media y al fin las llevaria ambas y muy bien pagadas $\mathrm{y}$ esto mismo hizo en muchos tambos de manera que llego a Potosí con su par de medias de seda y setenta y tantos pesos en plata y comio y bevio en el camino lo que quiso sin aver sacado de Iima tan solo un real.

Otro agravio resciven los yndios en los tambos y particularmente quando estan algunos españoles en sus pueblos de asiento $y$ es que les hazen guardar quatro o seys cavallos o mulas en el campo y por cada dia pagan medio rreal no mas como se dixo quando guardan y apacientan el ganado de la tierra o de Castilla y consertan poca la paga si se pierde un cavallo o mulo o le hurta algun pasajero o otra persona que es muy ordinario hazerse cada dia lo a de pagar el triste yndio sin rremedio y el precio le pone el dueño del cavallo $y$ si valia veynte pesos antes de perderse despues de perdido vale cinquenta $y$ si era mula $y$ de poco precio por lo mas vale despues de perdida dozientos y cinquenta pesos $y$ asi de ordinario suceden estas cossas $y$ es lástima ver los lloros $y$ llantos de los yndios que como dalles medio rreal de paga que no tienen para almorzar como esta ya dicho les obligan a pagar tanta plata y en conclucion no ay pasa. jero por infame que sea aunque sea un negro o mulato que no acocee $y$ azote $y$ maltrate a estos yndios con mas rigor $y$ crueldad que si fueran esclavos y como todas estas cosas y las demas arriva referidas nunca afloxan 
un punto $y$ siempre van en continuación $y$ aumento tantos son mayores sus cargas $y$ travajos $Y$ por todas partes estan tan oprimidos y perseguidos que si no se pone muy eficaz remedio sera impossible restaurar sus cossas al ser que tenian algunos años atras. algunas cossas se an callado por justos respectos $y$ por ser tales que se podria señalar como con el dedo quien las ha hecho $y$ esto se dize para que se entienda, que, no solamente ay $y$ se hazen todas las cosas sobredichas pero también otras muchas mas de grande ofensa de Nro. Sr. Y deservicio de S.M. Y perjuizio Y daño de los yndios.

\section{Capítulo XI. - En que se trata como se han huydo y huyen mu- chos indios a diferentes partes por los travajos sobredichos.}

Las cosas sobredichas y algunas más que se han callado an sido cau. sa y son para que los yndios se hayan huido de sus pueblos a los valles y quebradas con tanto exceso que con ser la Prov. de Chucuito ó haver sido, por mejor decir, la mejor y mayor poblada de quantas tiene el Perú está el dia de oy tan sola y sin yndios que a quien la vió aora 10 y 6 as. Y la ve agora dirá no tener ninguno y en los pueblos donde avia $1600 \mathrm{y}$ en otros 2000 y en algunos más de 3000, el dia de oy no ay presentes 150. En el pueblo de Juli que es de los dos mejores el uno, quando agora 20 as. le tomaron los PP. de la Cía. avia 16 a 17000 almas de confesion y baptizavan caảa domingo de 27 a 30 niños y agora estos últimos años y particularmente en este de 96 no ay casi gente que confesar y la que ay son mugeres $y$ algunos viejos $y$ los niños que cada $D_{0 m}^{\circ}$ se baptizan son como 3 o 4 y muchas veces no más de 2 y algunas ninguno $\mathrm{y}$ de 3200 indios que se empadronaron en la última revisita aora 16 as. no hallaran en el pueblo 150 . ni los PP. pueden juntallos.

Esto mismo sin quitar ni poner pasa en los demas pueblos y en alg!tnos pareze que ay mas esterilidad de gente. Muchos Domingos arreo se contaron en Juli todos los yndios de tassa que se juntaron a la doctrina $y$ nunca llegaron a 24 y en alguno no se juntaron 6 y como sobre los pocos que ay en toda esta Prov. $Y$ en las demas cargan los travajos sobredichos es maravilla que aya ninguno. Algunos años haze se decia que avia en los Chunchos que es gente de guerra muchos yndios huidos de toda esta tierra $y$ en fin se dize sea verdad $y$ aora poco ha salió della una persona muy tidedigna que aunque no los vió ni supo dezir determinadamente que tantos sean afirma ser ansi $y$ que es muy grande el número dellos y que cada dia van en mucho augmento. Supo esto de los mismos chunchos que eran muy amigos suyos y save tambien los nombres de los pueblos los quales no estan mezclados ni metidos dentro de los mismos chuncros sino a un lado que los divide una sierrezuela. a la una parte $y$ otra de los pueblos es montaña muy espesa donde a cualquier ruido o rebato que pueda aver se meten como en una fortaleza de donde es como impossible sacarlos. Tienen grandes sementeras de maiz y muchos frisoles y mani y camotes y yucas y mucha fruta como es platanos y guayabas y piñas $y$ otras muchas de la tierra. Tienen mucha caza de monte como es venados $y$ puercos que tienen el ombligo en el espinazo y muchas pavas $y$ otras muchas aves $y$ en lo que es savana muchas perdizes y muy grandes. Tienen en sus casas muchos pavos y algunas gallinas de Castilla; en los rios ay infinito pescado, de manera que tienen todo quanto an menester con mucha abundancia y excusan todos los travajos que acá padezen. Todos se visten de algodon y son ya 
graindes flecheros, particularmente para cazar y quando van a sus chácaras llevan sus arcos y flechas para matar alguna caza y los muchachos y algunos de los mismos indios ya ombres llevan sus cerbatanas con que matan muchos pájaros para sustentarse $y$ en fin tienen quanto han menester. Los de mas edad estan baptizados $y$ los que an nacido $y$ nacen de nuevo quedon hechos gentiles $y$ asi los unos como los otros biven y mueren co. mo bestias sin confesion ni conocimiento de Nro. Sr. y la causa de condenarse toda esta gente que ya era christiana y de la Yglesia an sido los muchos travajos que tenían que por no podellos sufrir se atrevieron a desamparar su patria y tierra y yrse a bivir entre gente- de guerra donde les parecio hallarian mas seguridad $\mathrm{y}$ descanso $\mathrm{y}$ este es un grandísimo daño asi para la christiandad de los mismos yndios como para el bien de todo el reyno porque en lo uno $y$ en lo otro abrá gran pérdida si con tiempo no se pone remedio en las causas destos males.

Los que van a los valles calientes muchos dellos se meten en unas quebradas que no ay hallarlos $y$ estan siempre como a la mira si viene alguno por ellos para huyrse y esconderse y estos como tienen chácaras de que sustentarse no quieren mas haziendas ni otros bienes a trueque de excusarse de tantos $y$ tan ordinarios travajos como en sus pueblos padezen $y$ estos de la misma manera que los otros viven $y$ mueren como bestias sin confesion ni memoria de Dios N.S. Otros ay que quando se huyen a estos valles hazen asiento con algunos chacareros españoles los quales con las informaciones que dan tienen maña para sacar provisiones de la Audiencia para que se los den por yanaconas perpetuos. Muchos destos van amancebados y viven y mueren en su mal estado como los demas arriba referidos. Porque de ordinario tienen su asiento donde no hay Cura. Otros hay que se conciertan en estos valles con algun Caciqule $\mathrm{Y}$ indios principales, los quales tienen algunas casas pequeñas en sus chácaras donde viven estos yndios huidos y quando sus caciques van a buscarlos para reduzirlos, escondenlos de manera que no ay hallarlos.

Destas ausencias síguense muchos daños: el $1^{\circ}$ como está dicho el que rreciven en sus almas. El $2^{\circ}$ es que por la falta que ay de indios no se podrá enterar la mita de Potosí. El $3^{\circ}$ como los pueblos estan con poca gente y los travajos que ay se repartion entre muy pocos corgan sobre ellos, ni lo podran sufrir. Lo $4^{\circ}$ a los mismos españoles y al comercio comun de todos es muy dañoso la poca gente porque quanta mas ay se compra y vende mas $y$ quanto menos uviere será menos lo que se ganare. Lo $5^{\circ} \mathrm{H}$ mismo Rey pierde mucho de sus rentas reales $y$ el dia de oy en menos de 2 as. tiene sola la Prov. de Chucuito mas de 50,000 ps. ensayados por co. brar y será bien dificultoso enterallos por la falta que ay de indios. Lo $6 \mathrm{c}$ quando $a$ los que están en Potosi holgazanes $y$ que no acuden $a$ la labor de las minas por obligación los apremian a que travajen en lugar de los que avian de ir de sus pueblos, ese dia se huiran todos a donde no los hallen porque los an de tratar como a los indios de cédula azotóndolos y acoceándolos $\mathrm{y}$ dóndoles muy poca paga obligándoles a que paguen las tasas de los otros $y$ sera dificultosísimo detenerlos obligándolos a todas estas cosas, porque un indio de cédula no gona en una semana sino 2 ps: y medio y travajan con mas rigor que los que se alquilan de su vella gracia y sobre esto pagan cada año 30 ps. de tasa y los que se alquilan quando quieren no pagan esta tasa ni travajan con tanto rigor como los de cédula ni son tan maltratados y sobre eso paganles cada semana 9 y 10 y 11 ps. Y algunas veces más y por esto repito que el dia en que les obligaren a travajar con las obligaciones $y$ cargas que tienen los indios de cé. 
dula ese mismo dia se huiran $y$ querer referir todos los inconvenientes $Y$ daños que se siguen del huirse $y$ ausentarse los indios de la manera que lo an hecho $\mathrm{y}$ hazen seria nunca acavar $\mathrm{y}$ todos los que tienen alguna experiencia deste Reyno saben bien que el dia que no tubiera muchos indios no valdra nada. Solo se porná en último lugar el principal que se a seguido de los travajos que an tenido $y$ tienen $y$ del orusentarse tantos temiendo el yr a Potosí de la manera que van y del traginar de la manera que se haze $y$ de todas las demas cosas ya dichas $y$ es que no tienen tiempo para enterarse en los misterios de Nra. fe y a los que savian algo con las continuas ocupaciones que tienen se les olvida y muchos de los que trajinan mueren en las punas sin confesion y los que se huyen a los valles $y$ los que se an ydo entre infieles viven $y$ acaban como bestias $y$ pues se dize que el título que el Rey tiene para gozar destos reynos es dar sacerdotes como los da a su costa para que estos yndios sean christianos poco importa que lo haga si los Corregidores $y$ otras personas $y$ algunos caciques lo estorvan $y$ impiden de manera que esten atrasados $y$ tan a los principios en las cosas de nra. fe como si no los tubieran, pues es ansi que lo más del tiempo estan muy ocupados y fuera de sus pueblos y quando buelven a ellos no saben cosa ni aun los que vienen de Potosí donde tien'en curas y muchos religiosos que les predican en sus parrochias, por la mucha $\mathrm{y}$ ordinaria ocupacion que tienen. Siempre les falta tiempo para aprender lo que an menester $Y$ desto tienen larga experiencia, como esta dicho, los PP. de Juli que quando buelven a aquel pueblo algunos yndios de Potosí es mucho enseñarles de nuevo $y$ quando estos que asi buelven quieren aprender algo los ocupan en trajinar $y$ en el servicio de los tambos $y$ en otros travajos ya referidos que es muy dificultoso enterarse de los misterios de nra. fe.

Cosa es tan conocida la diferencia grande que ay entre los indios que tienen quietud $\mathrm{y}$ asiento en sus pueblos a los que andan ordinariamente fuera dellos, porque estos, como está dicho, por maravilla se enteran en los misterios de nra. fe $Y$ cometen muchos graves pecados con la ausencia de sus cassas $y$ mugeres $y$ no hoyen sermones ni ven missa $y$ por el contrario los otros como acuden tan ordinariamente a la doctrina y particularmente quando gozan de buenos curas que con buen exemplo $y$ sermones les enseñan vese claramente la mudanza en sus costumbres el confesarse mas a menudo el rezar el rosario apartarse del vicio $\mathrm{y}$ de todo género de ydolatrias tienen mas conocimiento de Nuestro Señor $y$ mas respecto a las cossas de la yglesia y de suyo frecuentan el oyr missa y a la ora de su muerte se confiessan con muchas veras $y$ dexan muy encargado les digan missas $y$ en fin es tan clara la diferencia que son estos como religiosos en comparacion de los demas. Y pues la grosedad del Perú son los yndios que ay desde el cuzco hasta Potosí $y$ en estos no se consigue lo que el rrey manda en negocio tan grave que es el fundamento por el qual goza deste reyno, justo es $y$ muy obligatorio en conciencia y mucho mas de lo que algunos piensan que los corregidores $y$ demas personas que mandan pongan en esto rremedio pues lo puede aver y que en primer lugar acudan al servicio de Dios Nuestro Señor $Y$ de Nuestro Rey y que se haga lo que manda y quiere que si supiese lo que passa cierto es no consentiria que el Govierno que ay impidiese a la Christiandad de los yndios sino que antes la ayudase pero como algunos vienen de prestado $Y$ ponen los ojos en el interes y con los cargos de conciencia sobre dichos no ay mas memoria desto que si los yndios fueran bestias $y$ asi en las mas partes ni ay yglesias ni nadie se acuerda de hazellas sino unas rramadas no mas y si por el cui- 
dado de algun cura se a traydo alguna madera para hazellas muchas vezes la toman los corregidores para, hacer sus casas y en algunas partes se quisso poner algun cuidado en esto hizieron, iglesias de los tambos y cavallerizas y como los indios ven esto, y que una misma cassa que a servido de cavalleriza para bestias sirva despues para dezir missa y celebrar los oficios divinos muchos dellos vienen a tener un concepto muy corto de nuestra tee a lo qual no poco les ayuda el mal exemplo que an visto $y$ ven en los españoles a la continua, de donde se puede inferir que no ay que maravillarse nadie no sean mejores christianos de lo que son que harto mas ha que comenzaron los españoles con mas luz $y$ entendimiento que ellos $y$ aviendo visto mejor exemplo que el que ellos an dado aca y con todo eso es una migaja lo que un yndio haze en comparación de lo que un español haze. Los del pueblo de Israel quando los sacó Dios del Egipto vieron grandissimas maravillas y milagros muy extraordinarios y con todo eso por un poco de tiempo que se detubo Moisés en el monte hablando con Dios, vinieron a ydolatra y pues estos yndios no an visto estas maravillas ni milagros sino siempre muy mal exemplo y que los roban $₹$ maltratan todos es harta maravilla que aya entre ellos el conocimiento que de Nuestro Señor tienen y que en muchas partes se aya arrancado ya la ydolatria.

$\bar{A}$ todos estos travajos referidos $\alpha$ sobrevenido otro y bien grande ocho años $\alpha$ y es aver sido todos muy esteriles y como los yndios son pocos quando se les yevan sus chácaras no tienen tiempo para aderezallas como lo suelen hazer quando ay mas con qué remediar gran parte del daño que los yelos hazen y agora está tal toda la Prov. de Chucuito y lo mas de toda esta sierra por la falta de indios que aunque los años de suyo sean buenos será poquísimo lo que cojerán porque ni ay quien siembre ni ay nadie que tenga que sęmbrar sino qual o qual ni se pone remedio ninguno en este mal que vien pudiera avelle que como en muchas partes toman los Corregidores mucha plata o la que hallan en las caxas del Rey la traen empleadas en sus granjerías mucho tiempo y despues que estan ricos la vuelven; pudieran muy bien emplearla en comida $y$ prestalla a los indios $y$ que al tiempo de la cosecha volvieran el valor de lo que rrecivieron con esto vivieran muchos mas yndios y los ausentes sabiendo el beneficio que se les avia de hazer en sus tierras bolvieran de mejor gana, pero como está dicho todos buscan su interes sin atender a mas.

\section{Cap. XII.- En que se trata la razon que ay para temer no se pierda este Reyno dil Perú ó alguna buena parte del.}

Muchos hombres doctos y de buena consciencia an temido y temen que si no se remedian las cossas sobre dichas querra nuestro Señor tomar la mano y castigar este rreyno con permitir se pierda pues ay tantast caussas $y$ fundamentos para esto como es todo lo referido y para que mejor se entienda se hara de todo un breve epílogo $y$ tras el se porna la razon en que se fundan los que temen el castigo sobre dicho.

Adviertase pues el numero que cada año a ydo a Potosí de la provincia de Chuquito y proporcionablemente se juzgue lo mesmo de todas las demas. desta an pasado siempre de siete mill almas las que an ydo cada año. La riqueza que llevan, el ganado y la comida vale mas de trescientos y veynte mill pesos. La yda de Potosí la hazen a su costa y tambien la buelta $y$ en España quando uno lleva una mula de alquiler la buelta la pagan cunque buelva bazia y la dan de comer a costa del que la alquiló. ' hazen. 
a estos desventurados dexen y desamparen sus pueblos y los azotan y trasquilon $\alpha$ los que en algo repugnan y a los que coxen de los que se huyen en Potosí les pagan en un mes onze pesos y gastan mas de veynte y ocho y sobre ser tan poca la paga les obligan a pagar quatro tanta tassa de la que pagan en sus pueblos cbliganlos $\alpha$ entrar en las minas muy peligrosas donde mueren muchos y se mancan $y$ descalabran muchos y sobre esto los mineros tienen gran dureza y rigor con ellos sino sacan todo el metal que quieren y los azotan y castigan con extraordinaria aspereza. quando buelven a sus pueblos de toda la rriqueza que llevaron no traen cossa $y$ en el traje luego los conozen todos sin preguntarlo que vienen de Potosí, hechos pedazos y muertos de hambre pidiendo limosna a quantos topan que quiebra el corazón vellos y en lugar de descanzar quando llegan a sus cassas luego los ocupan en trajinar y los obligan a que se ausenten de su patria de donde nace gran daño en sus chácaras y pérdida en su ganado que se lo hurtan $y$ mucho mayor en sus almas que no tienen tiempo para saver los misterios de nuestra fee y como andan lo mas del tiempo por despoblados cometen muchas ydolatrias y muchos pecados de los quales escusarían muchos y casi todos estando en poblado en compañía de sus mugeres y viendo missa y oyendo sermones. La paga que rresciven por un mes son cinco pesos y gastan mas de catorze en solo comer y sobre esto los obligan a que enteren todo el ganado y vino o coca o cualquier otra cossa que traian si falta aigo dello si manifiestamente no consta averse perdido sin culpa suya y como no pueden dar iestigos a quien crea el que trajina no tienen rremedio sino baxar los ombros y pagar. Los yndios de todo el Collao cada dia son menos, los españoles más y sobre los pocos a de cargar el travajo que repartia entre todos, el balor de todas las cossas a subido a mucho mas el precio que dan y lo que se paga $\alpha$ los tristes yndios siempre se esta en un ser, quando les mandan hazer rropa no les dan con mucho lo que mereze su trarvajo $y$ eso poco lo toman los caciques y ocupan tanto tiempo en esto a las yndias que no le tienen para acudir a sus chácaras y para hazer vestidos para si $y$ para sus hijos $y$ por verse tan apuradas a acontecido que unas se ahorcan otras matan a sus hijos por no tener tiempo para sustentarlos. Algunos se conciertan con los yndios por quarenta pesos para que les den el servicio que acostumbran que vale mas de trescientos $Y$ quatrocientos pesos otros reparten en sus corregimientos vino y otras mercaderías y obligon a los yndios que a pesar suyo las compren, otros los ruegan con un modo que es peor que mandallo, y cobran a mucho mas de lo que vale de que nace no poder pagar la tassa, porque an gastado la plata que tenian en pagar lo que contra su boluntad les hazian tomar. Otros compran la tassa que los yndios avian de pagar como es maiz o chuño, y como son corregidores scicanla por menos de lo que vale $\mathrm{y}$ fuera de que hurtan al Rey esa cantidad despues si el año a sido malo cobran de los yndios la tassa no a como ellos la sercaron sino a como anda y al precio mas riguroso como se dixo que sacan a 6 ps. la hanega y la cobran a 12 y 14 ps. y como los indios son pocos muchas veces pagan la tassa doblada por si y por los ausentes, porque los Corregidores apuran $\alpha$ los caciques $Y$ ellos no tienen de quien cobrar. Otras veces cobran de las hijas y hermanas de los ausentes $y$ de sus mujeres que es lóstima ver sus lloros, $y$ el rigor que en esto $\alpha y$ no por una vez sino por seys y ocho y mas años en los tambos los acooean $y$ dan bueltas de azotes y muchos hurtan y roban a los mitayos fingiendoles dieron a guardar algunas cossas no lo aviendo hecho $Y$ de otras maneras y los obligan a guardar dos o tres meses cavallos y mulas y por cada dia les pagan no mas de medio real y si se les huye o pierde un cavallo - mula lo pagan por entero y muchos yndios temiendo lo que an de gastar 
y dar y los azotes cue an de recivir y que no les an de pagar y sobre esio ies an de pedir lo que no deven, rehusan grandemente el servir en los tambos. Ios ganaderos hazen guardar ducientos y mas cameros a un solo yndio y la paga es no mas de medio real por cada dia y come en un mes mas de catorze pesos y obliganlos a que an de dar por entero toda la manada y si falta algun camero pagan ocho o diez pessos por cada uno y como son tantos se esparsen $y$ por poca ocasion se huyen $y$ espantan $y$ otras van tras las obejas que topan y sienten de lejos y es ynpusible guardallos todos porque si ban tras de el carnero luego se esparsen los que dejan y temiendo esto se queda guardando lo mas.

Considerando los yndios estos $y$ otros travajos $y$ agravios que reciven se huyen a donde les paresce que no los hallaran. Otros ynstigados y persuadidos del demonio se ahorcan y desesperan y la caussa de tan triste suerte $y$ desventura suya son estas cossas referidas y los azotes y castigos que reciven de los corregidores porque no acuden a sus grangerias y de los pasajeros en los tambos y de muchos caciques que por sus yntereses los matratan y de los mineros en Potosí. y tambien lo hazen biendo tantas perdidas en sus haziendas y que no gozan de un dia de descanso. Y juzguen pues agora no los theologos $y$ letrados sino los que menos supiaren como sea pusible que luzga plata ganada con tantas ofensas de Dios Nuestro Señor y con perdida de tantas almas como son las de los que se ahorcan $Y$ de los que se huyen a tierras extrañas y de los que se esconden donde los unos $y$ los otros biben y mueren como bestias sin sacerdote ni quien les diga noda de nuestra fee: y como es pusible que aproveche plata que se gana con obligaciones tan estrechas de restituyción y de pagar el travajo a los desventurados yndios que aun no les dan de tres partes la una de lo que en rigor de conciencia y de theologia ay obligación. Muchos ay que maldizen a Dios, unos con gran despecho y otros desabridos con la obligacion que padecen y dizen que como es pusible que sea bueno y misericordioso pues permite en ellos tantos travajos $y$ que sean tan perseguidos $y$ maltratados de todos y que no aya nadie que no los robe y que con ser los españoles tan crueles con ellos $y$ roballes $y$ andar amancebados $y$ cometer muchos pecados $y$ ser muy malos con todo eso triunfan $y$ comen $y$ beven $y$ que to do lo bueno es para ellos $y$ para si todo lo que es travajo $y$ de esta consideracion les nace a muchos el adorar sus guacas y ydolos pareciendoles que quisa hallaran por esta via lo que desean y no ay dubda sino que la aflicion destos tristes yndios y tantos como mueren en las minas de Potosí y los descalabrados y heridos que ay y los muchos que se ahorcan y desesperan $y$ la gran perdida que en sus haziendas y almas tienen $y$ el roballes todo tan a la clara que todo esto deve clamar delante de Dios para que tome la mano y lo remedia pues hasta agora nadie o ninguno se acuerda dello y en estos agravios se fundan muchos, castigará Nuestro Señor este Reyno si con tiempo no se remedia y para temer esto ay en la divina escriptura muchos exemplos y traerse an dos o tres no más para abrebiar este discurso.

Quando Dios quiso libertar su Pueblo de Egipto dijo a Moysés estas palabras: He visto la afliccion de mi Pueblo en Egipto y he oydo su clamor por la dureza de aquellos que asisten a sus tareas y travajos y saviendo su dolor he venido a libertallo de las manos de los Egipcios en las quales se a de notar, lo primero, que no dijo Dios Nuestro Señor que queria libertallos parque los egipcios no les pagavan su travajo. Lo segundo, tampoco dijo los queria libertar porque los sacaban de sus cassas y su Patria y apartavan de sus mugeres y los llevaban de unas partes a otras, de manera que no tenían tiempo para aprender su santa ley y guardalla. Lo $3^{\circ}$. tampoco dá por razon porque los ocupaban en cosas donde peligraba la vida de muchos 
y su salud. Lo $4^{\circ}$, tampoco dice queria volver por ellos porque los trabajos y ocupaciones que de parte de los egipcios les venian gastavan $Y$ consumian su ganado y hazienda que se yban enpovreziendo (sic) cada dia mas. Lo $5^{\circ}$, tanpoco da por razon por quanto se huyen a tierras estrañas y se apartavan de su abitacion y pueblos por los travajos que padescian y se yban $a$ donde no tenian quien les prodicase su santa ley, les enseñase $y$ persuadiese a bien vivir. de todo lo sobre dicho consta claramente con quanto exceso y quan a la continua padecen estas cinco cossas y otras muchas mas. los yndios de esta tierra de manera que solamente dio por caussa bastante para querellos libertar de tan duro cautiberio y de que bio su aflicion. y oyo su clamor, la aspereza y rigor que tenian los que asistian a sus tareas $y$ travajos. Bease pues agora la dureza y rigor que ay con estos desventurados haziendolos yr contra su voluntad $y$ por fuerza como si fueran esclavos a la labor de las minas de Potosí y consumiendo y gastando tanta hazienda como llevan. la aspereza que ay con los que se huyen por escusar. se de tantos travajos, cómo los aprisionan, cómo los azotan y trasquilan y usan con ellos $y$ otras cossas. y mirese la que tienen en Potosí los mineros con la crueldad que castigan por solo su interes y con ver que se descalabran tantos cada paso en las miñas y que destos mueren muchos. y que sobre esto pierden sus haziendas $y$ que cada año se ahorcan algunos dellos por acabar de una vez con tantos travajos. con todo eso no se afloxa un punto en este rigor. A esto se junta la crueldad de los corregidores quando los yndios no acuden a sus grangerias y quando lo hazen con qué rigor cobran lo que entre ellos reparten por mucho mas de lo que vale $y$ como los obligan a que enteren todas las averias que ay en el trajin y esto mesmo haren los soldados y muchos caciques. usan del mismo rigor con sus yndios lo qual an aprendido de los españoles, y no a faltado quien por sus pasiones ay $\alpha$ enterrado un yndio bibo fuera de otros que mata $\alpha$ azotes y como es. tos se quedan caciques no ay yndio que se atreba a poner capitulo ni dar la menor quexa por el miedo que les tienen que despues se vengaran como ultimamente. lo hazen $y$ an hecho con algunos que tubieron animo para quexarse dellos. $Y$ a esto se añade el ausentarlos $y$ apartarlos de sus mugeres lo qual es ocasion de muchos pecados que cometen muy a menudo. asi ellos como ellas y de que esten muy atrazados en la fee por el poco tiempo, que sosiegan, $y$ en fin todos son sus enemigos y como los hallan con tan poca resistencia $y$ que nadie los ampara ni favorece todos los ra. ban y maltratan y acozean. Pues siendo esto asi con quanta razon sie puede temer tomara nuestro Señor la mano de libertallos de tal cautiberio dandoles mas ser y brio como lo hizo a los de su Pueblo en Egipto. que pues los ocupavan en hazer adobes gente devia ser bien abatida y con todo eso las ensalso y engrandecio y no se contentó con libertallos sino que juntamente castiqó a pharaon y su ejército y a todos los primogenitos de Egipto. $\mathrm{Y}$ sabrá Dios asestar a los culpados y castigar como lo hizo a los que contra su ley tomaron ciertos dones offrecidos $\alpha$ los ydolos como quenta en el libro: segundo de los Machabeos en el Cap. en donde dize que en una batalla que tubo Judas Machabeo con sus enemigos solamente murieron los que avian faltado en tomar de los despojos que les era vedado y asi es justo se considere esto $y$ se tema el castigo y la pena, pues ay tantas culpas y quando Dios dé a estos el ser y brio que tienen otros muchos y no mas con el gran secreto que ellos siempre tienen bastará para que en una noche puedan bengarse y matar casi a quantos españoles tiene el Piru.

Dize el Ecco. en el Cap. X: Regnum a gente in qentem transfers propter injustitias et injurias et contumelias et diversos dolos, que quiere dezir: que el señorio de un Reyno pasa de unos en otros por las injusticias $y$ inju- 
rias y afrentas y diversos engaños. Explícase este lugar de manera que por las 4 palabras se entienden 2 vicios, el uno es la soberbia que significa por aquellas dos palabras ynjurias y afrentas. El otro es la codicia procuIando adquirir hazienda con engaños lo qual se entiende por aquellas dos palabras injusticias $y$ diversos engaños. Pues vease la sobervia que ay en este rreyno en todos generalmente hasta los infames de la misma tierra y los que han venido de España azotados y afrentados que alla eran lacayos y asemileros como tratan a estos tristes yndios. hasta los mismos mulatos y negros azotándolos $y$ acocé́ndolos por qualquier cossa que se les antoja y muchas vezes sin por que ni para que tratándolos siempre de ladrones y perros. Y con la crueldad que un turco trataria $\alpha$ un christiano cautivo - como un ombre aspero y duro a un mal esclavo y muchas vezes les toman sus hijas o sus mugeres $y$ las llevan $\alpha$ donde quieren $y$ si hablan algo los matan a palos, y dexado aparte esta crueldad que con ellos se usa no ay ombre de quantos vienen de España, aunque alla aya sido un ganapan y de muy baxa suerte que en llegando aca no tenga una altibez y soberbia y un trato tan altivo, que no ay quien le espere $y$ en fin desde el primero hasta el postrero, tratan estos yndios mucho neor que a esclaros que es lastima pensallo y como los que vienen de España entran en este rreyno pisando $y$ acoceando yndios y tratándolos con la tiranía que los tratan y los an tratado los que primero vinieron ya no ay nadie que repare en ello antes pareze que es ley inviolable segun que la guardan todos. Deste punto avia harto que dezir pero lo referido arriva baste para no hazer prolixo este discurso.

E lo otro de la codicia y los engaños con que se adquiere la hazierda esta bien declarado en los capitulos arriva puestos que por engaño hazen yr a Potosí tantos yndios de la manera que van a los quales en los principios les ofrecieron muchas ganancias $y$ que alla no travajarian siempre todos sino un terzio de ellos $y$ ver que travajan todos $y$ que buelven tan per. didos y que muchos quedan muertos $y$ otros perniquebrados $y$ que los españoles enriquezen con su sudor $y$ sangre $y$ que no les pagan de ocho partes la una que mereze su travajo que es bien grande el engaño que en esto ay. Mirese tambien lo que hazen los corregidores quando llegan a sus repartimientos como ofrecen $y$ prometen que an de hazer justicia $y$ an de bolver por los yndios amparándolos en todas sus cossas $y$ con esto procuran grangearlos para poder vender entre ellos lo que quieren a dos tanto de lo que vale $y$ despues los apuran $y$ destruyen $y$ roban como se dixo en las tassas que cobran dellos por dos tanto de a como se vendieron en la almoneda y quando por buenos medios no puedan venderles el vino $y$ otras cossas a pesar suyo y hazen que le tomen por fuerza y le paguen como esta ya dicho a mucho mas de lo que vale y asi en todo y por todo quedan robados $y$ destruidos. En el trajin apenas resciven la $4^{\frac{1}{4}}$ parte de lo que han menester para comer y sobre esto les obligan a enterar todo el ganado y averias. En la ropa que les mandan aun no les pagan la mitad de lo quie mereze su travajo y ocupanlos de manera que apurados y perseguidos ni tienen tiempo para pagar la tassa al Rey y cometen otros peccados como se dixo en el capítulo terzero. Muchos los obligan por el concierto que con ellos hazen con manifiesto fraude $y$ engaño que por precio de quarenta pesos les den lo que vale mas de trescientos. El engaño que ay en hazelles guardor gonado con tan poca paga obligándolos a que le enteren todo. Bien manifiesto es el que resciven en los tambos como se dixo en el Cap. X y las muchas pérdidas que en todo tienen y los mismos que compran alguna cosa de los indios es con mill engaños y embustes. Uno dijo $\alpha$ ciertos indios que queria comprar dellos una manada de carneros $y$ hecho ya el concierto hizo 
traer un cofre en que fingia tenia tener la plata para pagalles y disimuladamente hizo que se herrasen todos despues abrio el cofre delante de los yndios y candava rebolviendolo todo y como no avia plata no lo hallava $y$ haziendose de nuevo, dixo que no se acordava la avia prestado el dia de antes $\alpha$ un amigo suyo y que se la bolveria dentro de dos dias y les pagaría sin falta ninguna y como los carneros estavan ya señalados con su yerro se los llevo sin que se lo pudiesen estorvar y ni los pago ni los pagará porque se fue donde no se save del. Arto avia que dezir deste ultimo punto, pero lo rreferido arriva y la continuación que ay en estos engaños y otros muchos basta para que justamente se tema que sin culpa ninguna de nuestro catholico rrey que tan justas y christianas provisiones da siempre se pierda este rreyno o parte del que se si executaran con entereza que monda huviera mas justicia y menos agravios y engaños $y$ los yndios estuvieran mas descansados y fueran mejores christicmos y asi ay obligacion $a$ prevenir este azote dando orden $y$ traza que las cossas deste rreyno duren $Y$ vayan a la larga y la corona meal goze de los tributos y rentas del perpetuamente que para todo puede aver rremedio y la gracia de todo esto es que el pagar mas a los yndios y las obligaciones tan grandes que ay de restituylles es de personas particulares y no del Rey como consta por lo rreferidio pues a su misma hazienda hechas las quentas, como se an de hazer con las personas que han tenido cargo y mando en este reyno, se deve grandissima suma de plata.

En el terzer Libro de los Reyes, en el capítulo doze dize la divina escriptura que quando murio Salomón y heredó su hijo Roboan todos sus rreynos, fueron los principales del a rogalle les aliviase algo del imperio aspero y duro $Y$ del yugo tam pesado que su padre les impuso $Y$ consultando el este caso con los ancianos de su Corte $y$ los que asistian a su padre y que tenian buen zelo, dixeronle condescendiese con su pueblo y les hablase con suabidad y blandura y que asi le yria muy bien, no le contentó este consejo y tomó el que le dieron los que se avian criado con el y de creerles le devieron de lisonjear y la respuesta que dio fue que si su padre agravó su carga, que el la avia de augmentar mas y que si su padre los castigava con azotes el los avia de herir con escorpiones. Lo que sucedió de esta respuesta fue que de doze partes que tenia su meyno perdió luego las diez. Pues razon sera se tema que si en este reyno siempre an ydo augmentando las cargas y travajos y los tributos y tassas a los yndios y rresciven siempre tantos agravios y se les paga tan poco por sus travajos $y$ en todos ellos pierden tanto de sus haziendas y muchos dellos la vida y el alma. no suceda alguna desgracia en este rreyno y tome Dios la mano en castigallo y pareze viene muy a propósito de lo que hicieron los malos consejeros de Roboan que procuraron hablalle $\alpha$ su gusto y lisonjearle lo que muchos deste Rivno hazen que es escrivir a los virreyes y quiza al Rey que los quintos rreales van en augmento y que la tierra esta muy gruessa y que ss bien paguen los yndios mas tassa y que ay gran numero dellos y que conviene se saquen mas para el trajin y para las minas de Potosí, como dor falsas y lisonjeras, relaciones que el año pasado tubo el Marqués de Cañete mandó que de todas las provincias de arriva de los de Chucuito saliesen más indios de los gue solían para las minas de Potosí y vióse por experiencia quán mentirosa huviese sido esta noticia que tuvo, pues de sola la Provincia de Chucuito faltaron de los 2200 indios que yban cada año más de 1300 , por. que no los ubo ni se hailó traza para poderlos enterar quanto más para embiar más. Y este año de 96 con averse puesto todas las diligencias posibles de parte del Governador y haver venido un juez de Potosí para enterar este número $\mathrm{y}$ haver recojido los caciques todos los yndios que han podido 
de los valles y dexar la Provincia despoblada no se an sacado sino mill $y$ veynte yndios y no se sabe los que llegaran a Potosí, estos avissos que se dan a los virreyes es para tenellos mas propicios pareziendo que con ellos se les da particular gusto y contento y que asi los sustentaran mas tiempo en sus oticios que es lo que desean los corregidores con lo qual tienen más mano con los yndios y ellos conoziendo que el corregidor a de durar mas tiempo témenle más y acuden generalmente a su gusto y casi ninguno escrive la realidad de lo que passa ni los agravios que ellos hazen $\alpha$ los yndios como $\alpha$ la hazienda del Rey y que van $\alpha$ Potosí y buelven $\alpha$ su costa y que consumen grandíssima cantidad de hazienda y enrriquezen a todo el mundo y ellos buelven sin un real y que cada dia van a menos $y$ rresciven otros mill generos de agravios como esta ya dicho y se ahorcan muchos por verse tan apurados $y$ perseguidos $y$ que cada peso cuesta su sangre y hazienda y sus almas. Solamente se da quenta de lo que pareze a de aplazer a los virreyes o al Rey como si su magestad y sus virreyes no pusieran los ojos sino en lo que es plata aunque se adquiriese con agravio y perjuicio de los yndios y en conclusión casi no ay corregidor ni español y plega Dios no aya otros que no quieran enriquecer en un año o lo más presto que pudieren $y$ an de comer $y$ bever $y$ vestir $y$ jugar $y$ dar a quien se les antoja y algarse $y$ hazer vajilla de plata $y a$ de sobrar buen golpe dello al cabo del año, y el triste yndio a de reventar y gastar su hazienda y la paga que resciven es conforme se aya dicho arriva. Poco ha que cierto religioso con particular licencia de su prelado admitió la hazienda de un deudo suyo que murió para embialla a España para un hermano del mismo Religioso. el qual lo primero que hizo fue poner los ojos en satisfacer todo lo que hallase y pareziese dever su deudo. el qual todo el tiempo que vivió tubo particular cuidado de pagar a los yndios que sirvieron en diferentes cossas lo que pareziales era devido con todo eso miró esto más desapasionadamente y considerándolo no por via de piedad sino con todo rigor de justicia halló despues de dejallas las quentas una $\mathrm{y}$ dos vezes que de cinquenta mill pesos ensayados se devian mas de los veynte mill. los quales dió a pagó en barras y avia todo este daño en la hazienda con que su deudo pagó siempre lo que parezia se devia, pues que será donde claramente no se paga nada o muy poquito. En esta Relación como se ha visto no se han puesto sino algunos de los muchos agravios que reciven los yndios de las provincias que acuden a Potosí. Restava dezir los que padecen otras personas junto con parte de los dichos en los obrajes yngenios de azucar, chácaras y haziendas.

Agora sera bien se digan los rremedios que puede aver para estos daños y los que an parezido a personas de mucha experiencia ser lo mas eficaz y mejores para que asi goze su Magestad con mas continuación sus reales rrentas y los yndios vayan en mas augmento y acudan con mas descanzo a sus travajos $y$ el orden que se tubo en dezir sus daños $y$ agravios ese abra en dezir los rremedios.

\section{Cap. XIII.-Er. que se trata de que manera se podrá continuar la mita de Potosí sin tantos agravios de los yndios y con mas seguridad de conciencia.}

Lo primero supónese que el obligar a los indios a que vayan a las minas de Potosí no se quitará y asi para que no les sea de tanta carga ni lo repugnen tanto es justo y devido en conciencia que se les pague en Potosí por cada dia lo que an menester para comer y algo más con que puedan 
vestirse y pagar la tasa pues esta ley obliga que la paguen y el vestir $y$ comer es forzoso pues $\alpha$ un esclavo está obligado su amo $\alpha$ dalle de comer y vestir y si no lo hace se lo puede tomar lícitamente. Tambien se considera que el indio ha de sustentar su mujer e hijos, pues es libre y a pesar suyo le hazen travajar para bien del minero. Ay obligacion a que la paga sea conforme $\alpha$ rrazon y justicia y aqui se advierta un punto de grandissima importancia para que esta paga se haga con gran gusto de los mineros y es que en ninguna manera se vendan yndios sino que al que tuviere minas se los den y al que no, no se los den porque aconteze que hazen merced $\alpha$ un hombre de veynte yndios y este no tiene minas y vendelos $\alpha$ uno que los tenga y por cada yndio le dom cien pesos ensayados y por veynte dos mill, esta plata era con la que el minero avia de pagar lo que en conciencia se devia al yndio, y el minero harto haze en dar al yndio lo que otros pagan y sobre eso dar a cuyos eran los veynte yndios dos mill pesos ensayados y esta es la razón como se apuntó al principio porque tienen mas ganancia los que labran sus minas con los yndios que se alquilan con su vella gracia que no con los que son de cedula, porque muchas vezes son estos comprados y los otros no y asi le sale mas barato al minero. Síguese de aquí que el indio podrá pagar la tassa a su Magestad con mas descargo y su Magestad será asi mas servido y los mineros andarón más olgados y notese mucho que el Rey terna los mismos quintos de la una manera como de la otra y que en esto no se quita un solo rreal a su hazienda.

Algunos que tienen más favor y tienen yndios y solamente miran por su interes responden que si al yndio se le pagase cada dia ocho rreales o lo que dan a los que se alquilan casi no abria ganancia y por lo dicho consta, quan maliciosa sea la respuesta pues lo primero a los que se mingan dan tres tanto que a los yndios de cédula y de obligacion lo qual no hizieran sino tubieran ganancia. Lo $2^{\circ}$ el que da por veynte yndios dos mil pesos ensayados a la vista no lo hisiera si con todo eso no sacaran ganancia en labrar con ellos sus minas y si le quitan que no los de bien podra pagar a los yudios lo que en conciencia $y$ en rigor de justicia se les deve. Lo $3^{\circ}$ quando el mismo no ganara nada pues al yndio le ocupan a pesar suyo en su servicio y le hazen dexar su casa y patria y lo que tiene ay obligacion a pagalle conforme a lo que esta dicho. $Y$ otros dizen que los yndios hurtan metal y que con eso se suple lo que se le avia de pagar, a esto se respende que en tiempo de don Francisco de Toledo hurtavan tambien metal $y$ de mas ley que el que agora ay y con todo eso la paga que entonzes rrescivian. porque todas las cossas eran muy baratas, era bastante para suplir todas las cossas sobredichas y asi será razon que sin tener atencion_a lo que pueden hurtar particularmente valiendo los metales tampoco se les pague por aver subido tanto el valor de las cossas lo que han menester para comer y bestir y pagar la tassa de la manera que se a dicho. Lo $4^{\circ}$ no hurtan todos los yndios ni pueden por la vigilancia que tienen los que asizten en sus tareas $y$ si hurtan a otros no satisface con eso el que puso cuidado a que no le tomasen nada.

Lo $5^{\circ}$ se dize que los que se alquilan son los que mas hurtan porque como son de ruego los tratan bien los mineros $y$ asi tienen mas lugar y li. cencic: para coger algunos pedazos de metal $y$ con todo eso les pagan tres tanto que al yndio de cédula y queda el minero con qanancia y es justo que entre christianos no se de por razon que si uno dexa de pagar es porque permite que le hurten que quiza lo saca el yndio con mala consciencia y pareziendole ser mal hecho.

Puede advertirse que como en España y otras partes suben y bajan jos jornales y el precio de mercaderias por la abundancia o falta dellas asi 
de la misma manera es muy conforme a rrazon que el salario y jornal que por cada dia se huviere de pagar a los yndios no sea siempre uno mismo sino más o menos conforme al valor y precio de las cossas atendiendo siempre a que an de comer y bestir y pagar muy gruesa tassa, y gastar algunas mantas en sacar el metal para el minero y tambien a de sustentar su muger e hijos y en esto no pierde el Rey nada y lo que los mineros ganaren será con mejor título y más, seguridad de conciencia. Parece se podia cometer muy acertadamente el tassar y señalar lo que se ha de pagar a cada indio por su trabajo, ponderando la ida y vuelta a Potosí y lo que gastan $y$ lo que comen con sus mujeres e hijos y lo que visten y la gruesa tasa que pagan al corregidor y $a$ todos los prelados de las religiones de la villa de Potosí acompañándose con sendos religiosos y que con juramento y firmas suyas dixesen lo que les pareciese en conciencia se avia de dar a cada indio y que eso fuese lo que pagasen todos.

Donde la llaga es grande el remedio a de ser proporcionado y el cauterio de fuego mas riguroso y assi conviene que a qualquiera que se le dieren yndios con titulo de que tiene minas o que los aya ya rrescivido por la misma causa se le tome juramento solemne que el dia que no tuviere mi. nas o no las quisiere labrar no los venderá en ninguna manera ni por si ni por terzera persona ni rescivira nada aunque se le de de gracia y benebolencia y que desde luego haze donacion de qualquiera cosa que rresciviere por qualquier via que sea por respecto de los yndios que vendió o prestó lo. tercia parte $\alpha$ los yndios y la tercia parte $\alpha$ su Magestad y la otra parte al que denunciare del luego.

Lo $2^{\circ}$ conforme al parezer de los mas baquianos y demás experiencia deste Reyno es mucho mejor que los yndios que van a Potosí vayan de una vez y los pueblen en los valles mas cercanos y mejores que ay junto al cerro $y$ las razones que para esto se dan parezen eficaces. estos yndios lo primero an de estar reservados de todo genero de trajin y de ayudar $\alpha$ hozer chácaras $y$ cajas $y$ de traer madera $y$ sacar asequias $y$ de otros qualesquier travajos. Lo $2^{\circ}$ es justo $y$ muy devido en consciencia que no obliguen $\alpha$ yr tantos a las minas como el dia de oy van ques con tanto exceso que no queda gente ninguna en los pueblos y asi acudiran con mas suavidad y gusto a las minas. Lo $3^{\circ}$ estando poblados cerca $y$ en tierra templada y abundante bolverse an los yndios brevemente a sus pueblos y si no uviere tantos en Potosí será esto de más dura y sus chácaras y abundancia de comidas los conbidara a que buelvan con gusto. Lo $4^{\circ}$ estando asi reduzidos haran muy pocas ausencias de sus pueblos $y$ sera esto parte para que vayan en grande augmento como se ve por experiencia donde estan los yndios de asiento $y$ quando fueren a Potosí como sera cerca, llevarán sus mugeres y quando no como la ausencia a de ser de tres o quatro meses no más y esto de tarde en tarde impidirá muy poco a la generación y augmento dellos. Lo $5^{\circ}$ evitarse han grandes amancebamientos de yndios que con la larga ausencia de sus pueblos que estan distantes se ocultan y estando asi cerca y bolviendo presto sabran los curas y sus fiscales lo que ay. Lo $6^{\circ}$ se quitará el escrúpulo y cargo de consciencia que agora ay de que no se les paga nada por la yda y buelta de Potosí porque estando ellos cerca sera poca la costa aue haran y pagóndoseles más por su travajo como está dicho, se suplirá eso poco que gastaren en yr y bolver $a$ sus pueblos. Lo $7^{\circ}$ quando falien algunos yndios del número de los que an de yr a las minas no sera menester embiar Juezes con dias y salarios y hazer tantas costas a los pobres yndios como cada dia se les haze arora por que con avisallo al principal que los lleva o tiene obligación de llevarlos se rremediara muy fácil. -mente. Lo $8^{\circ}$ estando estas cossas con este asiento y bolviendo los yndios 
presto a sus pueblos seran mas bien doctrinados, y mejores christianos pues ay experiencia que la larga ausencia que suelen hazer de sus pueblos daña grandemente a sus almas y los curas destos pueblos podrán con mucha facilidad tener padron y memoria de los que van $y$ buelven $y$ tener riqor en pedir quenta del que falta $y$ hazer este servicio a Dios Nuestro Señor y a nuestro rrey don Felipe. Lo 9', seguirse a gran provecho a las rrentas reales de su magestad pues no abra tantos rezagos porque estando los yndios presentes $\mathrm{y}$ en tierra abundante de maiz y otras grangerias que ternan serles a muy facil de pagar sus tassas. otras razones avia que dezir pero las refsridas son las principales.

Agora resta dezir qué tantos yndios se an de reduzir y el parezer que en esto ay de gente entendida es que, hecha la revisita de toda la gente se saque de 10 uno $y$ si estos fueren 1500 se embien 3 mitas al respecto de 10 y uno, que es harto aviendo de ser cossa perpetua y basta esto augmentándolo por 3 veces y observando las Ordenanzas de D. Fco. de Toledo vienen a travajar en las minas de 3 en 3 años y no más de 6 meses en el tercer año que es harto alivio para los indios y muy llevadero.

Lo $4^{\circ}$ estos indios que se an de reduzir es muy conveniente que sean los que están en los valles huidos y los que están en las chácaras de los españoles porque ni los unos ni los otros tienen raizes que los detenga y lo que hazen asi divididos eso an de hazer estando juntos que es cultivar chácaras y aunque los chacareros lo sientan mas razones miran por el bien común y por el servicio de nuestro Rey y bien de sus yndios que por el particular de algunos chacareros y a los mismos yndios se les hará harto bien para sus almas reduzillos y poblalios donde tengan sacerdotes que los confiessen y enseñen las cossas de Dios Nuestro Señor y ayuden $\alpha$ que sean buenos christianos.

Replicarán los chacareros diziendo que ellos acuden al bien comun con las sementeras que hazen proveyendo de comida a toda la gente de Potosí y otros pueblos y que es quitar el sustento a la tierra. A esto se responde lo primero que lo que ellos quieren ante todas cosas es su bien particular y cumentar sus haziendas y que los otros compren sus sementeras muy caras $y$ escudan y encubren su propio interés con dezir que acuden al bien comun y asi conviene que la reduccion se haga con gran rigor y qus aunque tengan los chacareros provisiones de las audiencias y birreyes pasados las rrompan y tomen juramento a los mismos chacareros y a las demas personas que pudieren dar noticia de los yndios que ellos y los yndios de los valles tienen $y$ de los que oviere sueltos sin estar en cassa de nadie $y$ advertilles que seran castigados por perjuros sino manifestaren la verdad. Lo $2^{\circ}$ se rresponde mas propiamente que estos mismos yndios chacareros rreáuzidos a tierra templada y buena harán muchas chácaras y ternan mucha comida $y$ lo que travajan $y$ coxen en chácaras ajenas $y$ para otros sem. braran y coxeran en sus propias chácaras y para si y mirarán por ellos con tan buena gana $\mathrm{y}$ gusto como por las agenas $\mathrm{y}$ asi no se quita el bien $\infty$ mun pues acudiran $\alpha$ el con abundancia vendiendo su maiz al precio que corriere y haran ellos con mucho provecho suyo lo que hazian quatro o seys chácaras o los que ay, antes con esto se acudira mas al bien comun pues daran y proveeran de comida a la tierra como antes $y$ los mismos vndios seran más mejorados y viendo ellos el interes al ojo gustaran de reduzirse y sera gran bien para esto que se les de provision para que siempre que llevaren comida o otras cossas a vender a Potosí o otras partes se venda en primer lugar $\mathrm{Y}$ sean antepuestos $\alpha$ todos los que no fueren yndios $y$ a los que lo fueren siendo de otras partes, $y$ el farorezellos en esto será tenellos con mas gusto en sus pueblos para acudir a la labor de las minas. Lo $3^{\circ}$ 
se responde que para que se acuda al bien comun será muy acertado que eslos yndios paguen a su Magestad alguna parte de su tassa en comida como es media hanega de maiz cada año y descontalle de lo que pagan en plata que su Magestad ganara en esto pues lo vendera bien y a los yndios se les hará buena obra pues les será fácil dar media hanega a cada uno viviendo en parte templada y abundante de comida, y siendo quatro mill yndios los reduzidos abra tantas cargas de maiz y bien se acudira asi al bien comun y el año que fuere esteril sera muy justo se les de privilegio que paguen en partes la carga de maiz o los esperen a otro año mas fertil. Lo $4^{\circ}$ se responde que no todos los yanaconas que tienen los chacareros son de los yndios huidos porque en los mismos valles ay muchos yndios que no van a Potosí $y$ todos hazian $y$ hazen muchas sementeras sin los que agora an ydo de la provincia de Chuquito $y$ de otras partes. Lo $5^{\circ}$ será muy justo para que esta reduccion se haga con mas suavidad y seguridad de consciencia que del ganado de comunidad que ay en la dicha provincia y en cada pueblo en particular se les de una buena parte del y que por lo menos sea la mitad para que tengan con que chacanear desde sus chácaras hasta sus cassas y para llevar a Potosí su ato y lo que uvieren de vender y para que tengan corne que comer $y$ lana de que vestirse $y$ para hazer rropa y despues vendella $y$ aun se les podria mandar que toda la tassa la pagassen en comida y ropa, en lo que no perderia nada el rrey y antes ganaria $y$ el dalles este ganado los aficionara a yr viendo que les don $y$ los alivian de otros travajos y en ninguna cossa pudria emplearse mejor este ganado que en esto pues ha sido $y$ es de tanto embarazo $y$ de tanta costa para los inciios que es más que lo que ello vale, porque en muchos años se han ocupado como trecientos indios en guardallo a los quales no se les a dado nada por su travajo y sobre esto los obligavan a que diesen la manteca ne cesaria para curallo del carache $y$ de rigor de justicia se les deve todo $y$ mucho mas por su travajo y dandoseles a los que se poblan junto a Potosí de tres partes las dos o a lo menos la mitad de todo el. se dara algun des. cargo de la consciencia y sera gran bien para ellos, agora se a quitado un mayordomo español que cuidava de todo esto $y$ es lo mismo que antes porque los yndios se ocupan sin paga ninguna.

El resto de este ganado se podra dor a los que se redujeren a la provincia para que tengan con que pagar la tassa a su Magestad y se puedan sustentar y buelvan con algun gusto. no faltara quien diga que desta comunidad se sacan cada año quatrocientos $y$ mas carneros $y$ que se venden para su Magestad $y$ que perderá esta rrenta repartiéndose de la manera dicha. a esto se responde lo primero que si su Magestad a de pagar a los pasiores que guordan el ganado antes quedora adeudado que aprovechado en este casso y en consciencia ay obligación a pagar a los pastores. Lo $2^{\circ}$ quando pagados los pastores tuviera alguna ganancia que no abra sino mucha perdida, grangeara sin comparacion mas repartiendolo de la manera dicha pües se recojerán los yndios huidos y pagaran su tassa cada año y no abra los rezagos que ay porque en este y el pasado pasan de cinquenta miil pesos ensayados los que se an dejado de cobrar por la ausencia de los yndios y cada año abra más de diez mill rezagados segun estan y ban las cossas y lo que montara este ganado cada año con el cargo de consciencia ya dicho seran tres mill pesos corrientes y cun menos.

Lo $6^{\circ}$ sera muy hacertado que los pueblos sean muy grandes y que en cada uno aya quatro parrochias y asi abra entre ellos más policia y mas comersio y mas gusto y conviene grandemente que los curas que aqui se pusieren sean sacerdotes escojidos y de exemplar vida o religiosos que burlando ni deveras no tengan genero de cobdicia ni pretendan plata para si 
ni para deudos de donde se seguirá que los yndios estaran mas obligados pues no los ocuparan en cossas de minas ni en otros travajos ni en chácaras ni hazer rropa y podran acudir con mas gusto al servicio de su Magestad y a la labor de sus minas y los yndios seran mas bien enseñados y rescivirán buen exemplo y si se quisieran dar estas doctrinas a religiosos aunque es verdad que an repugnado a tener doctrinas por no estar solos conoziendo el peligro que en esto ay, çsa en este caso la respuesta dicha pues los yndios an de ser grandes $y$ podran estar muchos juntos en una cassa $y$ tener el orden que en un comienzo y el mismo concierto y este punto es muy necescrio para la conservación de los yndios.

Lo $7^{\circ}$ se podra provar no poner caciques perpetuos en estos pueblos sino como dizen cadañeros $y$ en esto no se hara agravio a nadie pues en ca. da pueblo abra yndios de diferentes pueblos de la provincia y $a$ estos de cada año se les a de señalar un buen salario y obligarlos a que cobren la tassa y cumplan la mita de Potosí y que para todo esto traigan bora alta $y$ tengan escrivanos $y$ oros oficiales como ay en los demas pueblos y adverillos que al cabo del año les an de tomar residencia de los agravios que hubieren hecho $Y$ de los yndios que uvieren ocupado en sus granjerias $y$ de los que ovieren dado o vendido para las minas. Executándose esto asi y deponiéndole al cabo del año, cualquier indio agraviado dará sus quejas con mucho ánimo y confianza y con el miedo de la residencia no se venderán indios para las minas ni los ocuparán en otros travajos ni los harán muchos agravios que resciven quando sus caciques nunca dan residencia destas cossas y assi estarán los indios más holgados para acudir al servicio del Rey y a sus propias granjerias y serán de más dura. Y ay muy larga experiencia y muy conozida que quando un cacique haze agravio $\alpha$ sus indios, siendo perpetuos como agora lo son todos, no ay indio que se quexe dei ni por el pensamiento, por el gran miedo que le tienen $y$ porque sabe que se venga de cualquier cossa con gran rigor $y$ que puede despues hazelle mil molestias, como se las hazen, $y$ aun entre españoles se usa no poner capítulos ni quejarse de un juez poderoso, si ven que este ha de quedar en su throno $y$ merced $y$ que es algo vengativo, quanto más los indios $\alpha$ su cacique porque es mayor el poder y señorio que con ellos tienen que el $\mathrm{Vi}$. rrey con los criados y aun con los más bajos de su casa.

A esta traza podra ser repugnen algunos caciques ó los más y aleguen muchas razones para contradezillo y lo que les moverá es parecerles que les quitan sus indios y que no podran aprovecharse más dellos y que quizá se acavará mañana su poder $y$ bolveran a sus pueblos $y$ los ternan de tirano. Tambien les moverá y mucho ver que perderán grán parte de lo que cobran de los ausentes, porque como saben de muchos dellos dexanlos estar donde tienen hecho su asiento para que cobren a sesenta y a setenta $y$ a mas pesos no ternan esta grageria.

La respuesta desto esta muy clara y con todo eso se dize: Lo primero que ante todas cossas se a de mirar por el bien comun y no por el particular de los caciques y advertir tambien que estos yndios mas son del Rey don Felipe que no suyos dellos. Lo segundo a ellos mismos se les haze mucho bien con esta traza porque no dexan de ser muy perseguidos de los corregidores porque no enteran la mita de Potosí y la tassa de su Magestad lo qual nace de la ausencia de los yndios que ay muy pocos presentes y están los pueblos destruidos y rexuziendose el resto de la gente que a de quedar junto a Potosí entablarse han los pueblos antiguos y teniéndolos presentes podran cobrar sus tassas y acudir a otras obligaciones y los mismos yndios yran en grandissimo augmeno particularmente si se pone rremedio en los trajines segun lo mandó el marquez de Cañete y se dira mas abaxo $\mathbf{v}$ 
para que mejor se entienda que los yndios yran cada dia a mas asistiendo en sus pueblos es bien se note $y$ advierta que en un valle de tierra templada que ay aca aniva avia los años atras en quatro pueblos que se llaman Camata, Charagani, Mocomoco y Ytalaque un solo sacerdote y en todos ellos no avia gente para mas que un cura estos oy dia an ido creciendo de manera que el dia de oy ay en cada uno su sacerdote y es tanta la gente que tienen que es bien dificultuoso que un solo sacerdote pueda doctrinar y confesar y administrar los demas Sacramentos a la parte que le cave. Y adviertase que solamente entran en este numero los naturales de los mismos pueblos y no los advenedizos. La razon deste augmento es no sacallos a la mita de Potosí ni tampoco a trajinar sino con alguna moderacion y bolvienda. se presto $\alpha$ sus casas y como siempre estan en ellas y hazen vida con sus mugeres $y$ todos se casan escusan muchos pecados $y$ an $y d o y$ ban siempre en grande augmento $\mathrm{y}$ lo mismo sera en la provincia de Chuquito $\mathrm{y}$ en todas las demas que ay desdel Cuzco a Potosí el dig que se diere traza de que no hagan las ausencias que hazen de sus casas y pueblos y desto no ay duda ninguna porque bien se save que antiguamente en solo el Collao $y$ tierra fria avia muchos yndios $y$ en los valles calientes muy pocos en comparacion desotros y arto mejor les esta a los caciques y al Rey que los yndios esten presentes y vayan en augmento que no dexarles perder todo.

A todo esto dira algun cacique y quiza algunos que son ya mas ladinos que el hazer dos pueblos junto a Potosí de los yndios de la provincia de Chuquito $y$ otros de las demas provincias y reduzirlos alli todos, dedicándolos para la mita de Potosí, que esto es condenallos a minas y que antiguamente los tiranos no tenían mayor rigor con los christianos quando les perdonavan la vida que condenallos a las minas de metal. A ello se responde $1^{\circ}$-que como estan las cossas de presente, todos los indios estan condenados a minas con otras muchas cargas de trajin y tambo y otros travajos ya dichos y ninguno se escusa de acudir a todos ellos. Lo $2^{\circ}$, no los condenan a que perpetuamente travajen en las minas como antiguamente lo hazian los tiranos con los christianos. Lo $3^{\circ}$, observándose las cossas aqui puestas ternan mas alivio para acudir con suavidad $y$ gusto a la labor de las minas pues los reservan de trajin y tambo y de ayudar a hazer chácaras y otros travajos y como gente que esta ya dedicada solamente al servicio del Rey es justo ser mas favorezida y amparada que otra ninguna $y$ que sea castigado el que los maltratare con mas rigor que si maltratara a otros. Lo $4^{\circ}$, dándoseles la paga que es razon con que puedan comer y vestir y pagor la tassa atendiendo a que an de sustentar muger e hijos viene a ser el travajo muy moderado y ternan mucho descanso. Solomente ay una dificultad grande $y$ es obligallos a entrar en minas donde mueren muchos $y$ otros se descalabran como se dijo arriva pero el mismo peligro tienen agora los que van alla, y asi es necesario se mande con mucho rigor a los veedores de las minas que las visiten muy a menudo $y$ con mucha puntualidad $y$ arisen con tiempo de las que estan peligrosas $y$ que esto se haga con gran cuidado y executandose asi podran entrar con mas seguri. dad y asi supuesto lo dicho no es rrazon se compare su travajo al que los tiranos imponian a los christianos que eran con gran crueldad no pagándoles nada $\mathrm{y}$ dándoles muy mal de comer $\mathrm{y}$ cortando a muchos una pierna $\mathrm{y}$ sacándoles un ojo y ocupándolos perpetuarmente en este travajo.

Lo $8^{\circ}$ se advierta que para que estos yndios vayan en augmento $y$ su servicio sea de mas dura conviene que en acavando su mita los hagan bolver con gran riqor aunque sea esto contra el gusto de muchos mineros porque en comenzando a afloxar en esto se deshara todo y cun se huyran a diferentes partes $y$ conviene se castigue muy bien a qualquiera persona que 
admitiere ningún indio destos para sus chácaras y otros servicios para que asi esten mas seguros $y$ vayan cada dia con mayor augmento.

Lo $9^{\circ}$ como esta ya dicho conviene mucho que los yndios que se huvieren de reduzir en primer lugar sean los que estan huydos en los valles de Moquehua y Zama y en todos los valles de Laricaxa y de Cochabamba y Mizque $y$ otros valles porque estos son los mas dificultosos de reduzir y si el Piey no manda seán estos despues será muy dificil traer lo restante a la povincia.

Con este orden se sabran los yndios que ay y las doctrinas que puede aver y abra assi mas descargo de la consciencia.

$\mathrm{Si}$ se huviere de hazer la misma reducion de las demas provincias se rá muy acertado y que quitara todo genero de confusion que todos los yndios que se poblaren se nombren y señalen para su Magestad y paguen la tassa conforme esta dicho y si se quitare algo a personas particulares, encomendadas en los pueblos de donde se sacaren estos se podra suplir en otras partes que el Rey tiene y vacan cada dia y advertir que quiza muchos no cobran por entero sus tassas porque no pueden y ponderar esto para la recompensa. E asentando todo lo que esta dicho cesan todos los gastos y agravios que los yndios resciven yendo a Potosí de tan lejos gastan poco en yda y buelta por estar cerca $y$ eso se recompensa con pagar algo mas los mineros, pueden pagar la tassa y sustentarse travajan con mas gusto y ánimo no ternan perdida en sus haziendas, pues bolveran brevemente a sus pueblos no peligraran en las minas haziendo aya gran rigor con los veedores, bolveran con gusto $\mathrm{y}$ de buena gana $\alpha$ sus pueblos porque saven que an de descansar y que no an de trajinar ni acudir a otros travajos y que los curas los an de amparar en todo $y$ por todo siendo tales como se a dicho.

Lo $10^{\circ}$, para que los caciques y todos acudan a esto con mas suavidad es necesario y devido que el Virrey haga un compromisso con ellos con mucha fijeza y que sea negocio inviolable y es que tomada la cantidad de los yndios que se señalaren nunca jamas se sacaran más de la provincia por ninguna via ni manera $y$ los caciques se an de obligar a que si algun indio de los que se poblaren junto a Potosí se viniere a la dicha provincia lo haran bolver luego sin admitillo, burlando ni deveras, y de la misma manera su Excelencia a de poner muy gran rigor que hará volver $\propto$ sus naturales pueblos a todos los inciios que se huyen de unas partes a otras y si fuere menester de poder a los caciques para que con vara alta vayan a donde quieran que se huyeren o hayan huido $y$ sin que nadie ni ninguna justicia se lo puedan impedir, los reduzgan y traigan, a sus pueblos para que ai paguen la tassa y el rrey no la pierda, y mande con qraves penas, que ninguna persona, ora sea español, o yndio, o de otra qualquiera suerte, ad. mita para sus chácaras o obrajes o otras qualesquier ocupaciones o travajos a yndio ninguno forastero $y$ si en esto ay rigor abra mas memedio $y$ orden en todo.

El Virrey $y$ el Rey $y$ todo el mundo este satisfecho que si no ay mucho rigor y gran puntualidad en las justicias en no faltar ni torcer un punto a su obligación, se perdera el Perú y es impossible aya orden ni concierto en cossa y como el Virrey castigue $\alpha$ los corregidores que hallare culpados conforme a lo que disponen las leyes los que uviere de aver viviran con más cuidado y en fin para todo y para todas las cossas conviene gran. disimamente aya rigor y justicia con los Juezes que los mas lo que hazen es augmentar su hazienda robando $\alpha$ los yndios y tomando algo $\alpha$ su Magestad.

Podria ser que algunos informasen de manera que por sus intereses díesen $\alpha$ entender que lo mejor es que vayan los yndios como an ydo siem. 
pre $\alpha$ Potosí, y buelvan los que bolvieren y si esto se huviese de continuar es necesario ante todas cosas reduzir los yndios ausentes con gran rigor y advertir que los yndios no tienen ya cossa en sus antiguos pueblos y traellos a que mueran de hambre, y paguen tassa no teniendo de que seria crueldad $y$ asi es muy justo $y$ muy devido den a los que se redujeren siendo pobres algo del ganado de comunidad con que comienzen por que de otra manera es impossible de tenellos y si no les acojieren en los valles se huyran a los chunchos como lo an hecho ya muchos y perdera el Rey mucha renta que es toda la tassa que avian de pagar los huidos y faltara gente para acudir a Potosí y $\alpha$ otros servicios de que al rey vienen muchas ganancias asi que conviene dar a los pobres con que comienzen. Lo segundo les an de pagar la yda y buelta $\alpha$ Potosí pues les hazen yr $\alpha$ pesar suyo y a beneficiar haziendas agenas y si fueran esctavos les avian de dar de comer y bestir pues mucha mas razon ay se de esto a los que son libres y los hazen travajar por fuerza. Lo tercero en llegando a Potosí han de hazer bolver los de la mita pasada con el rigor y puntualidad que los hazen yr y que cada Corregidor o los caciques tengan facultad del Virrey para embiar a Potosí par los que an dexado de bolver, señalando una persona, que vayan con dias y salarios, y si esto no se executa muy puntualmente por mas que sel reduzgan los ausentes se tomaran otra vez $\alpha$ huyr, $Y$ se destruyran $y$ asolaran los pueblos como lo estan de presente sin que en ello puedan aver reparo, porque como esta dicho los yndios cada dia son menos y el número de los españoles mayor y los travajos muchos mas. Lo $4^{\circ}$ sera necesario que en Potosí se paguen mas como esta dicho y se guarde en todo y por todo lo arriva puesto. Lo $5^{\circ}$ se advierta que yran muchos yndios muy pobres, como de presente van $y$ an $y$ do siempre, que no tienen carneros en que poder llevar su hatillo y comida y asi sera necescrio que del ganado de ca munidad se les de algo porque crunque parezca que por esta parte se desminuira pero por otra parte se recompensará bien con lo que el yndio dorra en Potosí con su travajo y tassa.

Adviertase mucho por remate deste capítulo que el rrey en todo lo dicho gana y continua sus rrentas rreales y terna los mismos quintos de una monera que de otra $y$ no se pide sino que los que quieren enriquezer lo hagan con buena consciencia y como gente christiana pagando lo que de rigor de justicia se deve y no quedándose con lo que es de los yndios que bien poco podra luzir, lo que se gana con tan grandes obligaciones de restitución, que quiza es esta la razon y aun sin quizá porque luze tan poco la plata de las yndias.

\section{Cạ. XIV.-Del Remedio que puede haber para tantos daños $Y$ crgravios como los indios reciben en el trailn.}

Siguese ahora tratar del remedio del trajin y diráse también el parecer de los más baquianos $y$ más entendidos $y$ de mejor conciencia $y$ muy brevemente. Lo primero conviene en todo caso que se guarde y observe muy puntualmente to que el marquez de Cañete tiene mandado y es que el trajin sea de una provincia de yndios a otra y no mas y que asi se lleve el vino o la coca o el maiz hasta Potosí o adonde tuviere uno facultad para trajinar y con esto el yndio se ausenta poco de su casa y no tiene ocasion para quedarse en otra provincia, bolverá presto y podrá acudir al multiplico de su ganado y al beneficio de sus chácaras y la generación de los yndios yra en augmento siendo breve la ausencia de sus casas y mugeres y lo que mas es $y$ de mayor ymportancia no haran tantos $y$ tan enormes peca- 
tianos acudiendo a la doctrina a menudo y remediarse a el escrupulo que ay de que con tantas ausencias como agora hazen no se descarga la consciencia real que es un punto este de mucha consideración y digno de que aya rremedio en el -algunas provincias estan algo apartadas de los puestos hasta donde an de llegar con la carga como es la de Cavana hasta Arequipa y la de Chuquito y Pacages a Moquegua para la saca del vino y a estas con pagarseles mas se suplira el ser mas travajadas. podra dezir alguno que la provincia de Paria y Chuquito esta muy distante de Potosí respecto de lo que otras se apartaran de las suyas y que no sera pareja la distribución. Respondese que a todas se les haze gran beneficio. Porque la de Paria ba el dia de oy hasta Paucartambo por coca que son mas de dazientas y treynta leguas de yda y buelta $y$ arto bien se le haze dexe de caminar todo esto y que solamente vaya hasta Potosí que es muchíssimo menos y si algunos destos pueblos estan algo apartados del camino pueden salir veynte leguas o lo que fuere a tomar la carga pues aorraran mas de dozientas y beynte con solo esto y quiza se podra dar traza que el trajin pase por sus pueblos y adviertase que la coca que se trajere del Cuzco puede llevarse por Omasuyo, en fin se trate que por ambas partes de la laguna sea el trajin. Lo segundo se a de mandar y con mucho rigor que el trajin en ninguna manera sea en tiempo de barbechar las chácaras y de sembrallas porque es manifiesto agravio el que rrescivirian, sacándolos en estos tiempos como hasta aqui se a dicho lo que a sido y es gran motivo $y$ ocasion para que se ausenten, sino que se haga en tiempo que esten mas desembarazados $y$ devido es que en todo sean favorecidos y asi trainaran con mas gusto. Lo tercero se a de mandar se les pague lo que jastan en comer $y$ bestir $y$ algo por su travajo, pues se deve esto en consciencia $y$ an de pagar tassa, ya se dixo que por lo menos gasta un yndio cada mes en el trajin quinze pesos podra ser la paga a rrazon de a diez y ocho pesos cada $m=s$ y que esta paga sea en plata $y$ adviertase $y$ mucho que en esto no pierd:? el rey nada antes gana mucho, pues mira por la justicia $y$ el bien de los noturales y pues los obliga a pagar tassa, favorezerlos de manera que puedan acudir a esto y orta desventura es de los tristes yndios que siempre salgan con perdida en todas las cossas que los ocupan los españoles. También se pondere que estando los yndios presentes y no sacandolos de sus pueblos como hasta aqui se a hecho aunque repugnen desto los que trajinan se sigue otro gran provecho para la hazienda rreal y es que no abra tantos rezagos como el dia de oy ay que como esta dicho en solos dos años ay mas de cinquenta mil pesos ensayados en la Provincia de Chuquito y esto cesa. rá porque podran los yndios estondo presentes pagar muy mejor la tassa particularmente pagándoseles su travajo lo que pareziere deverseles de rigor de justicia y si aconteciere que barataren las comidas y las demas cossas o encarecieren más, se podra tener atención a eso para que la paga sea mayor o menor. Tambien se advierta que la paga a de ser por todo el tiempo que casta hasta bolver a su casa de manera oue sea yda y buelta, porque si hicieran esa labor para todo este tiemro les havian de dar de co. mer y vastir y más razon es se dé a los que son libres y los hacen trabajar por fuerza y ha de haber grom rigor que la paga sea en plata pues los yndios pagan la tassa en plata $y$ si es en vino lo beben $y$ se emborrachan Y pierden su trabajo. Lo $4^{\circ}$ para que el trajin no sea con demasia importa mucho que, hecha la minuta del vino que será necesario en Potosí y Chuquisaca y tambien la coca, dé el Virrey provisiones a los beneméritos y ombres de bien y no perpetuas sino para un viaje y no más porque dándolas perpetuas esta cierto olvidanse de las que estan dadas $y$ que cada año $s$ dos y idolatrias como hazen con la laraa ausencia y seran mejores chris- 
den mas y que los que las tienen las den a otros y estos digan que es suyo el ganado y que se ganó la provision para si y es necesario cerrar bien este portillo $\mathrm{y}$ poner graves penas $\mathrm{y}$ perdimiento de todo el ganado $\mathrm{y}$ lo que en el llevare al que se ayudare de estas provisiones para mas que para un viaje o las diere a otro. Tambien importa mucho que al que se le diere la tal provision se le tome juramento que directa ni indirectamente no dara a nacile la dicha provission ni la vendera ni trajinara para otro y que por el mismo caso haze renunciacion de todas las ganancias a Su Magestad y mas de otros dos mill pesos al denunciador $\mathrm{y}$ con esto se remediara que si alguna persona quisiere trajinar no lo pueda hazer por el estado que tiene o por ser juez o por otras rrazones se remedio mucho de ello. Lo quinto en. tablado esto asi se sabra en cada provincia los yndios que an de acudir al trajin y los que les caven a cada pueblo y que los caciques y alcaldes no esten obligados a dar ningun yndio sin que se les muestre la provision. Lo sexto para que esto se haga con mas concierto es bien y conviene que de un pueblo se den a un español los yndios que le caven y no de diferentes pueblos y que llsven un principal el qual se obligue a bolvellos todos y quando alguno quiera huirse no le sera tan facil $y$ el cual sera justo haga minuta de los que van y a la buelta mire si falta alguno. De estar estas cossas con asierto se rremediara el gran agravio que resciven muchas yndias que es pagar la tassa por sus maridos y padres que no se save dellos muchos años $\alpha$. Seguirse $\alpha$ otro muy grande y muy digno de consideracion para la hazienda rreal $y$ es que como iran los yndios en grande augmento abra mas ynäios que paguen tassa $y$ asi abra mas rrenta $y$ en fin en todo sera Dios Nuestro Señor mas servido y el Rey y su hazienda rreal mas augmentodo y mandando que los corragidores no traten la plata que-cobran de Su Magestad embiarse ha mas a tiempo pues no la traeran empleada en sus tratos y grangerias que uno de los enemigos que tienen los yndios es la plata que esta en las caxas del rrey porque por medio della los ocupan los corregidores en trajinar $Y$ hazer rropa y otros travajos. Lo que se a dicho del trajin es necesario se execute de la manera dicha aun quando huviesen de reduzirse los pueblos ya dichos junto a Potosí, pero haziendose la reduccion alla que es lo que mas conviene no será necesario tanto trajin pues los yndios que estaran cerca de Potosí proveeran de mucha comida a aquella villa y ponderese tambien que tanto vino como se lleva a Potosí no le bevan todo los españoles sino los yndios $y$ no es razon se permita tal pues se sabe se emborrachan por poco que beban del y gastan en eso la plata que tienen y con la que avian de pagar la tassa. Fuera desto ya se van plantando viñas y coxiendo vino cerca de Potosí $y$ por todas vias ay razones para que el trajin sea con mas moderacion $y$ adviertase que en todo es menester rigor $y$ puntualidad en guardar justicia y no tanta codicia. Lo septimo se mande al que trajinare que el vaya en persona con los yndios que fueran de una provincia a otra con el ganado y carga o que mande un mayordomo que lo haga porque asi conste que la botija de vino que se quebrare o el carnero que se huyere o muriere fue sin culpa de los yndios y si la ubo se sepa lo que an de pagar, $y$ si an de obligar a los yndios a enterar todas las averias la paga a de ser mayor de rigor de justicia $y$ en consciencia pero yendo un mayordomo o yanacona con los yndios ni ellos hurtaran ni abra necesidad de eso. Lo $8^{\circ}$ conviene que la paga se haga antes que salgan de su pueblo los yndios como se suele hacer parte della, pero entablado el trajin como se ha mandado es mejor que toda la paga se haga de antemano y podráse tassar qué tanta havrá de ser, conforme a los dias que se tardarán que esta cuenta será fácil de hacer y concertar la ida y vuelta. 
Lo $9^{\circ}$, en llegando el ganado a otra provincia an de obligar al corregidor de aquel distrito que luego de pastores mientras salen los yndios y descansa el ganado para que los que fueren con el se buelvan luego con su principal como esta dicho.

Algunos españoles repugnan grandemente a esto porque sentiran mucho el sacar tantas vezes yndios y diran que el ganado pierde mucho en andar en tantas manos y querrion ganar plata con mas quietud y mas provecho. La respuesta esta en la mano que si se sacan como hasta aqui y hazen tantas ausencias se siguen todos los inconvenientes dichos y no es mucho que travaje y cuide que arto bien le hazen y a lo que es que el ganado no es bien ande por tantas manos. Se responde que no ay español que no lleve uno y dos yanaconas con el y llevan sus toldos y miron por el y les daran fastores y si es pobre, el lo podrá hazer a ratos y travajar que quiza en Castilla devia de cavar o andar al estribo de otro y no ay para que hazerse aca cavalleros.

Guardandose todas estas cossas se remedian todos los inconvenientes que se pusieren en lo del trajin y sera un grandissimo bien para los yndios y a cada sacerdote se le podra dar una provision moderada para que pueda traer el vino y arina que huviere menester para su casa y sino tubiere carneros tomalle juramento como se dijo arriva que no la dará ni venderá ni se aprovechara della: Los corregidores ternan cerrada la puerta a lo menos por parte del Virrey. Verlad es que para que no traten requiere remedio muy eficaz y riguroso y mill vezes riguroso.

Si se averiguare que algún Cacique o alcalde vende yndios o trajina a de aver rremedio muy eficaz y castigo exemplar y sin que aya perdon $y$ que sepan los yndios y se les diga que si no ay provision y les pagan muy bien que nadie los puede obligar. Verdad es que es tan grande el miedo que tienen a los Caciques que sino les atan bien las manos no dexaran de dallos por los cohechos que resciven pero como se castiguen bien se remediorra.

\section{Cap. XV. - Del remedio que a de aver para la ropa que hazen hazer los Juezes para que ni los yndios ni Su Magestad sean defraudados en nada.}

En lo de la Ropa se dize en una palabra que el remedio es mandar con extraordinario rigor que no se haga ni aya corregidor ni sacerdote ni hombre nacido que la pueda mandar hazer. Lo segundo que los correjidores en ninguna manera la puedan comprar para si quando se vende alguna partida della. Lo tercero que tampoco obliguen a los yndios a pagar la tassa en ropa si tienen privilegio para poder pagar en plata porque lo ordinario va'e mas la rropa que lo que esta tassado en plata y eso demas se lo toma el comegidor para si. Seguirse ha de aqui que los yndios enrriquezeran porque venderan la rropa a mas y pagaran la tassa con mas facilidad y estaran mas presentes en sus pueblos viendo que no los apremian a hazella como hasta aqui se ha hecho y los años esteriles ternan con que comprar comida que lo que suelen hazer es llevar dos o tres piezas de ropa a los valles y con ellas rescatan maiz, y todo esto es bien de la hazienda rreal que estaran los yndios mas ricos y mas olgados para pagar la tassa.

El rigor que en esto a de aver a de ser muy grande y tambien en los caciques para que no cobren de sus yndios la tassa en rropa. Si ellos quie. ren $y$ pueden y esta a su eleccion el pagalla en plata porque vendiendo el 
yndio la pieza de rropa gana más de 10 pesos y estos, los toma el cacique el dia que cobra la tassa en ropa porque entera la caxa a como está tasada la rropa y véndela a como anda que casi es a dos tanto.

Lo $4^{\circ}$ no sucederan los casos que an sucedido por apremiar las Justicias a hazer ropa que a sido ahorcarse algunas indias y otras matar a sus hijos por no tener tiempa para contentarlos. Lo $5^{\circ}$ estando los indios más holgados no habrá rezagos de las tassas reales y en conclusión justicia y vigor y más justicia en los que mandan.

\section{Cap. XVI.-En que se trata del remedio que a de aver para las mitas que hazen los yndios.}

El remedio para las mitas que suelen hazer los yndios donde dan mas trezientos pesos de cossas por precio de quarenta es claro y facilissimo si se executa y el que aya grandissimo rigor en los españoles que no rescivan de los yndios ni yerva ni leña ni guevos ni cossa ninguna sino es pagándolo luego de antemano y en esto no se haze agravio a ninguno y sera bien que $\alpha$ los sacerdotes, se les pongan penas graves de parte de sus perlados para que executen esto, y a los rreligiosos sus provinciales y quando algun seglar o eclesiástico faltase plata como la buscan para jugar y contratar mas rrazon sera la busquen para pagar lo que piden y toman. Y porque en este rreyno ay muy pocos menudos y son muy necesarios para poder pagar lo que cada paso se compra sera muy justo se mande fundir en Potosí muchos reales senEillos y medios rreales y asi se executara esto con mas facilidad y suavidad, porque ay muchos que amontonan algunas deudillas por no tener menudos con que pagar y despues como se van unos $\alpha$ unas partes y otros a otras quedomse mill cossas sin darse a sus dueños: Executóndose lo sobre dicho se sigue: Lo primero que viviran todos con mas seguridad de consciencia y sin escrupulos que por maravilla ay quien dexe de tenellos que no pagare de la munera dicha. Lo segundo muchos que son muy largos en gastar miraran lo que hazen y se yran a la mano, y particularmente viendo que an de pagar a todos los mitayos aorraran de no tener tantos y será esto gran bien para todos que no aya tantos yndios ocupados en servir que acontece que si es uno casado ay mitayos para el marido y mitayos para la muger, para el hijo y para la hija y para la criada y como lo hallan todo barato y que no se paga nada o casi nada rresciven los pobres yndios un travajo incomportab!e. Y adviertase que es menester hazer pagar bien a los mitayos y asi no abra tanta rotura en esto que llega ya a tanto que hasta los negros dan mitayos en algunas partes, y con las alas y favor de sus amos hazen mill maldades. Este punto se concluye como los pasados y es que aya rigor y justiticia y muchas veras en executar esto que asi en lo dicho como en todo lo que se dira no se pide misericordia para los yndios sino justicia y mas justicia, algunos clérigos podría ser alegasen que los yndios suelen dalles pescado y otras cossas de gracia, y cierto cura que dezia esto, una vez que le mudaron a otra parte, luego le pidieron la paga dal pescado que le dieron en tres años y la pagó y dezia que era costumbre dallo de gracia, en todo es justo aya remedio. 


\section{Cap. XVII.-Del remedio que ay para los agravios que muchos corregidores hazen a los yrdios de su repartimiento ven- diendoles algunas cossas a mas de lo que valen.}

Facilíssimo es el remediar los daños que los corregidores hazen en sus distritos como se execute lo que está mandado y es que no traten ni contraten, pero toda la tierra a hecho burla deste mandato porque tratan agora tanto $y$ mas que antes. Algunos han querido denunciar a ciertos corregidores porque trataban y contrataban teniendo esperanzas que elejecutoria lo que el Marqués de Cañete habia mundado. Pero ellos supieron informar de manera que todo se hizo noche y supieron sacar provisiones para continuar lo que avian comenzado y hasta agora no se ha visto castigar a nadie por estos contratos de la manera que el dicho Marqués de Cañete lo mandó.

Tambien dizen muchos que si antes contratava el corregidor con algunos paniaguados aora an de contratar muchos mas para que absueltos dellos puedan ellos tambien contratar y para que se halle por escrito que son otros los que compran y venden y con esto con cumplir con la corteza de la ley que les pareze satisfacen a Dios $y$ al mundo $y$ todas las cossas vedadas $y$ prohibidas permiten se vendun entre los yndios por ser lo mas suyo dellos y antes cue huvierc esta prematica tratava el corregidor en su nombre. Verdad es que todo anda ton roto que casi no ay ninguno que haga caso dello y pareze que expresamente se a mandado que traten $y$ contraten haziendo los agravios que pudieren. Bien se pudiera remediar todo esto como huviese mas justicia pero no aviendo mas de la que ay y aviendo corregidores con dificultad abrá remedio. Ya se dixeron los daños que se siguen de sus contratos, los provechos que pueda aver no aviendolos son los siguientes. El primero como los yndios no ayan de comprar por fuerza estaran mas olgados para pagar la tassa y no abra tontos rezagos. Lo segundo no se ausentaran de sus pueblos que por las vejaciones que rresciven forzándolos $a$ que tomen y paguen lo que no an menester se huyen a diferentes partes $y$ estando preseries y escusando estos agravios abra cada dia mas yndios y mas tassa. Lo tercero no diran tantas maldiciones a Dios ni haran tantas ydolatrias viendo que lo que se les dize no conforma con lo que se haze y que no ay fuerza en nada ni se la hazen a que a pesar suyo compren lo que no han menester $y$ a precios tan excesivos que de verse tan apurados cometen muchissimos pecados de despecho y de desesperacion. Lo quarto se advienta que en todas estas cossas es Su Magestad mas servido y quedan los yndios con mas caudal para acudir a pagar sus tassas y a servir en sus minas y averiguadamente son mejores christianos, y descarga Su Magestad mejor su consciencia $y$ en conclusion como aya rigor $\mathrm{y}$ justicia se remediaran estas cossas.

\section{Cap. XVIII.-Del remedio que a de aver para que las tassas del Rey se vendan por lo que valieren.}

Ya se dixeron los grandes daños que se siguen, de sacar los correqidores las tassas para si y de la manera que lo hazen donde o hurtan a Su Mcaestad o roban a los yndios. el remedio de todo esto es facil si se exeta. Lo primero si la tassa que deven los yndios es comida y el año es esteril entonces y siempre que lo fuere se a de mandar que enteren la caxa en anda que es a mucho más de a como se remató, si es ropa la que se ven- 
plata a como esta tassada la misma comida. Porque ora sea el año bueno ora esteril la comida en muchas partes esta tassada de una manera y quando el corregidor cobra de los yndios la comida en plata a dos tanto de $\alpha$ como esta tasada por el rey o de a como se rremato en el almoneda todo aquello demas se toma para si, y lo roba a los yndios. Lo segundo se a de mandar con extraordinario rigor, por que el ordinario no bastará que el corregidor ni por si ni por terzera persona ni por ninguna via, ni para si ni para otro so pena de pertimiento de bienes $y$ de mucho mas que esto no pueda sacar la tassa pa si quando anduviere en pregones (aviendo sido el año bueno) sino que la saque el que mas diere de donde nacera que se pujara el balor de lo que se vende y en mucha cuantía y todo eso terna de mas Su Magestad y no se lo hurtaran los corregidores como se a hecho hasta aqui, que si se huviera de restituyr, lo que por esta via se a hurtado, pasa de un millon y si se dijese más quizá se diria verdad. Lo terzero para que esto se haga como deve, conviene que en ningun caso ni por ninguna via se venda nimguna cossa destas asi de comida como ropa o ganado sino es estando las cossas presentes, para que no sean molestados después los indios que en esto haya grandissimo rigor y porque quando se vende la comida, no estando presente el que la saca y en quien se remata, cóbrala haciendo medir la hanega muy colmada y si no hay comida cobra a como anda que es a mucho más de a como se remató, si es ropa la que se vendió por pregones, despues para cobralla hazen la hazer muy buena y que valga por lo menos a dos tanto de a como la dan al Rey. Si son carneros cobran los escojidos y que valen tambien dos tanto de a como el Rey tiene mandado se den $y$ cobren de manera que roban a los yndios en grandissima cantia $y$ ay tan gran rigor en esto $y$ tantos azotes $y$ tanta aspereza que la que ay en las galeras es regalo $y$ asi conviene $y$ mucho que no se venda nada sino es estando presente y que no compelan a los yndios $\alpha$ dar mas comida ni mejor ropa ni carneros que como Su Magestad lo tiene mandaāo. Executándose esto los yndios quedan mas olgados, y pueden acudir mejor a pagar la tassa a Su Magestad y a servir en las minas, $y$ destos robos se sigue el huyrse los yndios a diferentes partes y daño a la hazienda rreal por los rezagos que ay por los ausentes $y$ en conclusion atar bien las manos a los Corregidores $y$ oficiales, reales $y$ justicia y rigor $y$ entablallo bien que si esto falta no se hará nada.

\section{Caro. XIX.-Del remedio que a de aver para no cobrar do los yndios la tassa doblada.}

Remediadas las cossas referidas y haziendo pueblos junto a Potosí como esta dicho y asentando el trajin como se apunto y dando el orden que es rrazon en todo lo demas los yndios no estaran ausentes sino muy presentes y asi no se cobrara la tassa de los presentes por los ausentes porque estos no los abrá ni las mugeres pagaran por sus maridos que no se save dellos ni las hijas por los padres ni las hermanas por los hermanos y será muy facil hazer la revisita a menudo $y$ si creciere el número de los yndios crecerá la tassa y si se disminuyere sera menor, pero es cierto que yran a mas $y$ en todo abra orden y concierto asi que el rremedio deste punto esta en remediar lo demas y remediarse ha que los caciques no hurten tanto como algunos hurton como se a apuntado. 


\section{Cap. XX.-Del remedio que ha de aver para el agravio que los yndios resciven en guardar ganado.}

Muy notorio es el gran daño y agravio que los yndios rresciven en guardar ganado asi de la tierra como de Castilla, como se dixo crriva y el remedio que a de tener es: Lo primero que se les pague lo que han menester, para comer mas o menos, conforme al valor de las cossas que esto claro esta es devido en consciencia y so pena de restituir y no ay barbaro que en esto ponga duda. Lo segundo en España fuera de lo que es comer se paga mas a un pastor aunque no pague el tributo que estos yndios pagan y assi es devido tambien se les pague mas para ayuda de su tassa y al vestirse y sustentar su muger e hijos. Verdad es que les podran dar a estos alguna paga en came para que coman pero el resto a de ser en plata con que paguen la tassa y compren comida. Lo $3^{\circ}$ se note y pondere que la paga sobre dicha se da en España por solamente apasentar el ganado en partes donde engorde, $y$ asi si an de obligar al yndio a que entere el carnero que se huye $\mathrm{y}$ qualquiera otro de que no pueda dar señal clara y manifiesta que murió de biejo o de enfermedad. Tambien ay obligacion a que la paga sea más por solo este punto, como lo dizen todos los telogos y que tanta aya de ser esta paga, podránlo dezir dos o tres letrados enterados del vaior del ganado y del riesgo que a cada paso hay de que otros hurten del. que poco ha pasó un indio por las estancias de ganado hacia Potosí, como que iba de camino $y$ a las tardes oteaba donde podia hurtar y a la media noche hacia su lance. Despues los pastores como guardan tanto ganado no pueden contallo cada paso y quando quieran como ay tantas quebradas $\mathrm{y}$ cuestezuelas entienden que andan por allí $\mathrm{y}$ entre estas $\mathrm{y}$ estas el ladrón va caminando con su hurto, y por no perder la manada que tíene dexa de yr tras el ladron y assi este vino a meter en Potosí como treynta y siete carneros rasos que valian más de tresientos y cinquenta pesos y camo los pastores no pudieron dar señal de que se murieron o los mataron leones o zorras uvieron de encojer los ombros y desembolsar. Y assi conviene se les pague aparte mas por solo esto pues los obligan a enterar la manada siempre que no dan clara escusa de que no fue su culpa el faltar algun carnero, y si esto no se executa assi y con rigor abra gran traviajo para los pastores. Lo $4^{\circ}$ Conviene y es muy necesario que a los mismos caciques los obliguen con gran rigor a que paguen a sus pastores que muchos o casi todos no lo hazen, y tienen en esto muy gran falta... y seguirse $\alpha$ deste rremedio gran provecho para los yndios pues acudira a sus tassas con mas facilidad y no hurtaran el cuerpo $\alpha$ este travajo tanto ni ternan tanta ocassion de huyrse comn la tienen por la perdida que allaan siempre. Item los mismos españoles se ajustaran mas $Y$ andaran mas moderados sin dar tanto travajo a los yndios viendo que la paga a de ser mas y conforme a justicia y no todo de mogollón.

\section{Cap. XXI.-En que se trata del remedio que a de aver para que los pasajeros tengan buen avio en los tambos y los yn- dios no rrescivan tantos agravios en ellos.}

Para que en los tambos aya algun remedio requierese alguna mu danza como en todo lo demas aunque en algunas partes se baya entablando lo que aqui se dirá. Lo primero será muy conveniente y aun muy forzoso que en cada tambo aya un español ombre de brio y ser que se encar- 
gue del y de recado a los pasajeros, y que para ellos solos el solo puleda vender maiz y vino y carne. Lo $2^{\circ}$ los $\alpha$ de proveer de lo que pidieren los caminantes conforme al puesto en que estuviere de tal manera que ni en lo poco ni en lo mucho no an de acudir a nada a los yndios ni an de tener que entrar y salir en cossa con ellos. Lo tercero para que esto se haga mejor los alcaldes del pueblo donde estuviere el tambo o los que estan obligados a dar indios si el tambo esta despoblado al tiempo de cojer la hierva an de acudir a ayudallo para que la recoja y pueda hinchir dos buhios, o mas della para que despues acuda a dar recado con mas suavidad porqup si acaso no la hallan en tiempo seco pueda echar mano de la que tiene guardada. Lo $4^{\circ}$ an de acudir los yndios a dar toda la leña que pudieran al mismo tambero para que provea della a los pasajeros y asi la hierva como la leña y qualquiera otra cossa que, dieren los yndios se les a de pagar de manera que casi an de dar los indios lo mismo que agora. Lo quinto el tambero como esta ya dícho $\alpha$ de ser hombre de brio y para las vezes que se desvergonzare algun pasajero con algun yndio a de tener bara y comission dey Virrey para prendelle y hazelle informacion $y$ remitillo al juez mas cercano aviendo primero satisfecho al injuriado $y$ en algunos casos como es coces o buelta de cavellos o azotes o otras cossas semejantes y de poco agravio se le podra dar comission para que sentencie al que hiziere algo desto. Lo sexto conviene $y$ mucho que en llegando el pasajero pidiendo lo que ha menester ante todas cossas dé la plata para que se le traiga y podrá quedar presente un Alcalde hasta que se le entregue la leña y yerba y carne y maiz o lo que pidió y le dejen en el tambo sin tener más dares y tomares con el y que no haya obligacion a dalle mitayo para que le sirva, porque si es pobre el mirara por lo que tiene y se aderezará de comer y acudirá a lo que uviere menester. Y si fuere rico y aunque sea de moderado caudal siempre trae uno o dos yanaconas $Y$ estos podran aderezar de comer, $y$ dar recado a las cavalgaduras $y$ hazer todo lo demas $y$ harta comodidad y muy mucha se la haze al pasajero en dalle lo que a menester y lo que se puede hallar en el paraje donde se halla. de executarse esto ansi siguense grandes provechos para los yndios porque de antemano quedan pagados lo que an dado, y como no se encargan de guardar nada de lo que trae el pasajero no terna despues que pedillas, como lo hazen muchos sin avello dado ni pagaran tanto los indios como siempre pagan $y$ estas dos cosas son muy diạnas de rremedio. Lo otro aviendo tambero a quien respeten los pasajeros no pediran cossas que no las ay ni puedien dallas los yndios, que muchas vezes los azotan y acocean, porque no acuden luego con ello $\mathrm{y}$ en algunas partes piden gallinas aviendo muy pocas y costando al triste yndio una gallina un peso y $\alpha$ vezes diez reales, vienen a dalla por quatro $y$ piden destas cossas al tambero el respondera con libertad, si las ay o no 0 a como se an de pagar, y quedara rremediada la molestia, que los yndios padecen, y a algunos pasajeros les estara bien ahorrar la plata que avian de gastar con los mitayos que avian de servilles en los tambos y quiza se remediara con esto alguna parte del gran abuso que ay de pedir al mitayo le traigan una yndia para ofender a Dios y podra ser se escusen algunas ofensas que se hazen contra su divina Magestad. Lo septimo es necesario que la leña y yerva y guevos $y$ otras cossas, $y$ las perdizes se tasen por mas plata, y en algunas partes que ay menos destas cossas, sea mayor el precio porque cuesta grandissimo travajo $\alpha$ los yndios el hallarlas y traellas, aconteze muchas vezes comprar un yndio diez guevos, por quatro rreales y en el aranzel dize que se dé por uno, y el pasajero como apura y azota al ynaio para que se los traiga viene a darselos por un rreal, y lo mismo su- 
cede en las perdizes que las compran $\alpha$ tres $y$ a quatro rreales, y despues las dan las que son mayores $\alpha$ rreal y las menores a medio rreal, conforme el aranzel manda y lo mismo es en otras muchas cosas, y como los que hazen mita en los tambos se ven obligados a dar estas cossas, y los pasajeros los maltratan y acozean para que las traigan a trueque de no padezer tanto, dan por un rieal lo que les costo quatro $y$ por quatro, lo que les costo ocho, $y$ todas estas cossas quedan rremediadas con que aya tambero a quien acudan a pedillas $y$ a quien las ayan de pagar, y no seran algunos tan largos en gastar y pagar sean las cossas como valen, y sera tambien muy conveniente que como se dixo paguen ante mano estas cossas porque ay muchos pasajeros que no lo quieren hazer, porque dizen que no vale tanto, $y$ otros ay que quando les piden la paga de dos o tres cargas de yerva, si acaso sus cavalgaduras no las an comido toda aunque quede pisada $y$ esparzida $y$ sin provecho dizenle al yndio que la recoja y que no le an de pagar más de las dos cargas de las tres que trajo, y en fin quedan rremediadas muchas cossas destas con pagar de antemano y que aya tambero a quien las pidan $y$ buelva por los yndios. Lo octavo ordinariamente $y$ siempre tiene el tambero en su cassa tozino y carne $Y$ quesos y pescado $Y$ pasas $y$ higos $y$ miel y pan $y$ vino y otras cossas para los pasajeros y los proveerá muy bien y ellos se alegrarán de que haya este recaudo donde quiera que llegaren que será de grande alivio para todos hallar que comer porque la rrazon que a muchos caminantes les mueven a mal tratar a los yndios es porque no les dan lo que piden para comer, y como muchos llegan con ambre o todos al tambo no ay que espantar que algunos maltraten $\alpha$ los yndios. Lo nono sera muy conveniente que si a un yndio le hazen guardar cavalgaduras en el campo lo primero le paguen por cada dia al respecto de lo que comen quando irajinan, pues gastan eso mismo quando guardan las cavalgaduras, y conforme al valor de las cossas podra ser mas o menos lo que se les diere. Lo segundo si obligaren a estos yndios a que paguen lo que faltare es devido en consciencia se les de otra paga diferente de la que Iresciven por apasentar los cavallos y siendo assi podra ser que los pasajeros viendo que les cuesta toda mas plata no se detengan tanto $y$ justo es pues un yndio a de comer $y$ vestir y pagar tassa y sustentar hijos y muger y le mandan que juntamente con traer las cavalgaduras en buenos pastos pague la que faltare sea la paga conforme a mazon $y$ justicia teniendo atencion a todas estas cossas. Lo decimo se a de mandar que quando los ha. rieros llegan a los tambos y embian sus requas al campo vaya siempre un yanacona o negro suyo con las mulas y que no obliguen $\alpha$ un solo yndio a que las guarde y las asegure. harto hara en que vaya con el yanacona - negro $y$ las lleve a buen pasto porque ay muchas mulas que buelven a la querencia y el yndio que las guarda como no save donde es queda obligado a pagalla fuera de que muchos pasajeros se ven con necesidad y hurtan muchas cavalgaduras. Lo undezimo para que aya moderacion en algunas demasías es justo se mande que no aya obligacion a dar yerva para tanias mulas regaladas y de carga como traen algunos pasajeros unas vezes por su regalo y otras por otros fines. Lo duodecimo es necesario se mande con mucho rigor se execute lo que don Francisco de Toledo mando $y$ es que no den $\alpha$ un pasajero sino dos carneros el uno para la cama y el otro para la petaca, porçue ay alqunos que llevan tanto carnaje que dejan despoblados los tambos y son tantos y tan ordinarios los pasajeros que no es posible dar recaudo a todos $y$ muchas veces acontece detenerse un dia y cios por no hallar un apire para passar adelante y pues desde la ciudad de Lima hasta la del Cuzco no dan apires y quando dan un cavallo alqui- 
lado cuesta tanta plata. justo es que oya tambien rremedio en esto de aca arriva. Item es devido de justicia que por cada apire se pague mas de lo que se paga cada dia recompensando la yda y buelta de manera que por cada legua se pague un rreal a cada apire $y$ al yndio que fuere con el se de medio tambien por cada legua y con esto queda recompensada la buelta y ponderando lo que a de comer el yndio y lo que se suele llevar por fletar cameros vara ser esta paga muy devida. Ytem no an de obligar al yndio a enterar mill baratijas y cossas que les entregan sino sola la cama y si rresciviere otra cossa que se la den bien liada y que lo entere de la manera que lo rresciviere y con esto se evitaran muchos agravios y daños que hasta aqui siempre an rrescivido perpetuamente de los pasajeros que les piden lo que no les dieron $y$ hazen tantos juramentos con tantas amenazas que el yndio no tiene otro rremedio sino encojer los ombros y dalles los carneros que lleva. Lo dezimo tercio conviene que si el pasajero no quisiere pagar al yndio su travajo pueda el tambero que esta en el pueblo adonde llega abligalla a que lo haga y si fuere menester le prenda pora que con esto acudan los yndios de mejor gana a servir a los pasajeros pues estan ciertos que los an de pagar. Lo decimo quarto se a de mandar con mucho rigor que los caciques y alcaldes acudan al tambero con las cossas que se puedan hallar segun el asiento y puesto del tambo como son guevos $y$ pescado y otras cosillas para que asi aya mejor recado para los pasajeros. Yten an de estar obligados a tener leña y yerva para todos los pasajeros, la qual se lá an de pagar de antemano como se a dicho. Támbien es necesario que a sus tiempos, con parecer del Cura y Cacique y del Corregidor si estuviere cerca, le den al tambero los indios que hubiere menester para traer maiz y otras cossas para la provision del tambo y que el dicho tambero pague a los indios por su trabajo lo que es razón. Lo $15^{\circ}$ por quanto los tamberos ganarán mucha plata en estos tambos es bien que se arrienden cada añe y que la mitad se de a Su Magestad y la otra a los yndios y esta ultima mitad se podra repartir de la manera que pareziere al Corregidor $y$ al cura y al vicario.

De aver tamberos de la manera dicha se seguira gran provecho y ea que a!gunos pasajeros no hurtaran con tanta facilidad tantos cavallos $y$ otras cossas como hurtan pues sabran que los an de seguir los yndios $Y$ an de haliar juezes que los prendan y agan pagar en qualquier pueblo que llegaren.

Dexados los provechos ya dichos que se seguiran del executar estae cossas abra uno muy porticular y es que como no an de robar a los yndios como lo han hecho hasta agora muchos pasajeros y sobre esto los an de pagar lo que es justo y no los an de maltratar con azotes y cozes no se huy. rau de los pueblos como lo an hecho y hazen por temor del servicio del tambo $\mathrm{y}$ ternan con que pagar mas descansadamente su tassa y biviran con menos carga. Iten abra muchos yndios $y$ yndias que traigan algunas cossas $\alpha$ vender a la plaza viendo que se guarda justicia y los pasajeros ternon mejor recado $y$ esto se a comenzado ya hazer en una 0 dos partes $y$ es grande alivio para todos. Yten aviendo tambero se podra acudir al servicio del tambo con menos yndios. Yten los pasajeros a una mano ternan mas alivio y descargo particularmente los de buen termino y ombres de bien hailando en cada tambo lo que an menester. aunque cueste mas plata. Yten los mulatos y negros $Y$ muchos mestizos no haran tantos agravios ni robos ni tantas fuerzas como cada día hazen y en conclusion asi para los españoles como para los mismos yndios es muy buena esta traza y tambien se re- 
mediará los grandes $y$ inumerables peccados que cada dia ay sirviendo las indias en los tambos por no aver indios.

\section{Cap. XXII.-Ers que se pone el remedio de algunas cosscrs que arriva se tocaron y se apuntan otras con que se conclu- Ye este tratado.}

Ya esta dicho que a los yndios que se redujeren a sus pueblos por quanto vernan pobres $\mathrm{y}$ sin ganado ni otra cossa ninguna sera muy conveniente les den alguno de la comunidad y de lo restante seria acertadissimo para los años esteriles se vendiese una buena parte del $Y$ se comprase semilia y se prestase $\alpha$ los pobres para que tubiesen que sembrar y al tiempo de la cosecha la pagasen y con esto no se huyrian y abria mas seguridad en cobrar la tassa $\mathrm{Y}$ aun a los mismos que de nuevo se redujeren es muy necesario se les preste semilla con que puedan comenzar y buelvan con mas gusto, de que se seguira cobrarse la tassa por entero. Bien acertado fuera que un gran golpe de semilla quedara en deposito para semejantes necesidades que si el ynga se aprovechaba desta prevencion y tenia en muchas partes destos Reynos muy grandes depósitos de comida con que rremediava los años estériles y los gastos de guerra, harta razon avia para que governando christianos y de más conocimiento y policía que él, tubieran en esto alguna semejanza $y$ que huviera prevención para los años estériles, que si asi se huviera hecho no huviera tantos ausentes ni huidos ni tantos rezagos en la tassa y ellos con la asistencia en sus pueblos fueran mejores christionos y huvieran acudido mejor a otras muchas cossas que agora no pueden. El remediar la necesidad de los pobres en años estériles y el ejecutar lo que aqu se apunta se podria cometer en cada provincia al corregidor y al vicario della y a otros sacerdotes y en la de Chuquito se podría añadir el Rector de la Compañía de Jesús de Juli, y siendo tantos evitarse ya que no se aprovechasen destos depósitos porque entre tres o quatro puede aver mal concierto siendo todos diferentes y como dizen quando uno no quiere dos no barajan.

Remediadas las cossas ya dichas se responde a la amenaza que justamente se teme que es aviendo justicia y procurgndo que en todo se haga lo que Dios y las leyes mandan se podra esperar de su misericordia que este reyno yra siempre mas adelante y sera Nuestro Señor servido que luzga mas la plata que despues de rremediadas estas cossas se sacare de lo que hasta aqui a luzido la que se a llevado a España que no es mucho se deshaga como la sal en el agua la que va manchada con tantas obligaciones de restitucion y con tantos pecados como los yndios cometen por verse tan apurados y perseguidos de los españoles ahorcándose y despeñándose y otras vezes maldiziendo a Dios como a cruel, que tantos travajos permite vengan sobre ellos.

A todo lo dicho se podra añadir o quitar lo que mejor pareziere que en esto no se pretende sino que Dios Nuestro Señor no sea tam ofendido y que se rremedien tantos pecados y agravios como ay y que Su Magestad sea mas servido $Y$ sus vasallos sean bien tratados conforme $\alpha$ justicia y que goze con mas perpetuidad $y$ seguridad de consciencia de los tributos y rrentas deste reyno. 
Otros muchos agravios que resciven los yndios se pudieran referir como es el servirse muchos vezinos de los de su encomienda pagándoles muy poco o nada y en esto tienen algunos grandíssimo exceso y en cobrar las tassas en especie cumpliendo los yndios con su obligación pagóndblas en plata que es la mitad mas $y$ sus mayordomos hazen $a$ vezes muchos agravios y los que hazen los oficiales y alguaziles de corregidores son inmumerables y particularmente los que suelen embiar a algunas estancias para reduzir los que estan en ellas $\alpha$ los pueblos los quales no executan con rigoi el quemar todas las estancias y traer los yndios a poblado sino que rresciven muchos cohechos destos yndios $y$ otras vezes les toman lo que tienen diziendo que estan obligados a pagalle sus derechos y a la postre se quedan como de antes y siempre quedan estancias que reduzir $y$ una buena occision para robar a los yndios y los que esto an mirado de cerca todos afirman que las personas que embian los corregidores a hazer estas reducciones no pueden llevar ningun salario de los yndios quanto mas roballos sino que el corregidor esta obligado a reduzillos en persona y que lo que gasta y come en un pueblo eso mismo gaste en hazer estas reducciones $Y$ si huviere de embiar alguno lo haga a su costa.

Tambien rresciven grandes agravios de los chacareros que les pagan poco y les hazen travajir mucho y en los obrajes que en muchos de ellos se an ahorcado algunos de los yndios por la gran crueldad y tirania que con ellos usan fuera de otros muchos pecados que cometen por estar tantos juntos y tan a la continua. Y aora estos ultimos dias ay en todos los tambos muchissimos pecados por la falta de los yndios que en su lugar hazen mita $y$ irven las yndias $y$ muchachas $y$ en conclusion se rrequiere una vissita general y que se cometc a personas de ser $y$ brio $y$ de mucha verdad $y$ que sean desinteresadas y que hagan justicia con mucha rectitud y que los salarios se les señalen de bienes de comunidad y de culpados $y$ que no sean de los yndios por los muchos inconvenientes y murmuraciones y agravios que la experiencia a enseñado ay quando dellos se cobran. Y en la misma vissita se descubrirán muchas cossas, como es los yndios que ocultan los caciques y se sabrá lo que ay en esto y pagarán la tassa a Su Magestad $y$ algunas cossas que se callan de propósito se entenderón mejor después $y$ en tin se reformará en gran parte este rreyno, y se ara gran ser' vicio a Dios Nuestro Señor y al Rey y ayudará mucho para que aya continuacion en sus rrentas reales y mucho augmento en la cristiondad y bienes de los indios. Muchos caciques hay que se obligarán a entonar su tassa y a dar los indios para el trajin de la manera dicha, si les quitan que no tengan Corregidores y casi todos los yndios alzaran las manos al cielo el dia cr.e se vean sin ellos y al Rey ahorrará todos los salarios que les da y mas lo que a Su Magestad le toman todos los años de la manera que se a ya äicho y los yndios quedaran mas descansados para serville y pagar su tacsa y gustaran de vivir en sus pueblos y poco se podra aventurar en pro. var esto en tres o quatro años y asegurarse ha de que la plata que toman de las caxas y la traen ampleada en sus grangerias de lo qual es bien poco servido Su Magestad se embie con tiempo a España que todo esto y otras :inzchas cossas se encubren con dezir que vienen a hazer justicia $y$ favorecer a los naturales y con la bara del Rey se aprovechan muy a su gusto de la misma hazienda del Rey, y para los agravios que pueden hazer los espa. ñoles a los yndios y para las diferencias que ay entre los mismos españoles puede nombrarse algunos alcaldes $y$ estos por muy breve tiempo $y$ de ranera que no tengan que entrar ni salir en cossa ninguna de los yndios ni puedan cobrar tassa ni repartir yndios ni hazer otra cossa ninguna en- 
tre ellos y como esta dicho haziendose visita general se advertira de otras cossas mas particulares.

Si con todo lo dicho pareciere que aya corregidores, que bien pocos ay de los desapasionados que tal digan, son necescrias dos cossas. La primera es que pues se les manda que no traten ni contraten se les de un buen salario con que puedan sustentarse porque el que agora tienen no les basta para tres meses. Lo segundo es necesario se les tome juramento delante de + y de un escrivano real que no tratarom en ninguna manera con los ynóios ni por si ni por terzera persona, ni en su corregimiento ni fuera del, porque no se concierten uno con otro y que no solamente no contrataran para si de la mamera dicha pero ni aun para sus deudos ni parientes ni para otra ninguna persona y que por el mismo caso hazen donacion desde luego de todas las ganancias y del principal que pusieren la una parte para el Rey y la otra para los yndios donde trataren y la otra para el que denunciorre aviendo primero prgado $y$ satisfecho los daños $y$ agravios que huvieren hecho a los yndios fuera de que an de estar sujetos a las penas que le fueren impuestas como perjuro y quebrantador de las leyes del Reyno y sto se a de escrivir delante de los testigos $y$ firmarlo el mismo corregidor, authorizarlo el escrivano $\mathrm{y}$ luego tomarselo $\alpha$ leer $\mathrm{y}$ hazer que se rectifique en el juramento $y$ cun plegue a Dios que con todo esto se remedie.

Hecha la revisita general no ay duda sino que segun estan los pueblos se quitaran algunas dectrinas por la poca gente que ay para doctrinar y quando no se quiten es necesario que el salario de los sacerdotes sea mayor particularmente donde es muy tenue el pie de altar porque quando agora diez y seis años y algunos antes se señaló lo que se avia de dar era mucho y agora es al reves que todas las cossas cuestan mucho y el pie de altar en todo lo que es puna casi no vale nada y aumentándose estos salarios quítase la ocasion que algunos sacerdotes pobres podrían tener de tratar y contratar $y$ en la visita general se entendera mejor que tanta cantidad se aya de añadir a cada docrina $y$ en quales no se aya de añadir.

Un muy grande abuso ay en este rreyno y es que los vezinos ricos y crintratan con tanta demasía que los pobres soldados siempre andan arrag. trados $y$ un yndio que hallan les cuesta de coechos $Y$ dádivas tres tanto de y los corregidores y otras personas de caudal y mando son las que tratan lo que estos otros pagan y uno de los fundamentos que puede aver para temer aya algun alzamien:s es ver tantos soldados pobres $y$ que no tienen tras que parar ni cómo poder ganar la vida y que todo se lo llevan los que mandan $y$ los vezinos $y$ otros ombres de caudal $y$ asi sera muy necesario para asegurar por todas partes este rreyno, que los vezinos ni los corregidores ni otras personas que mandan ni otros poderosos puedan tratar ni contratar ni por si ni por otra persona de la manera que se ha dicho de los Corregidores sino que solamente traten $y$ sontraten los soldados pobres que viéndose ocupados en grangear hazienda con la cobdicia del interes ternan los ánimos quietos y sosegados $\mathrm{y}$ si les cierran la puerta para estas grangerias no es mucho tengun pensamientos altivos $y$ siendo los soldados pobres los que an de trates y contratar no maltrataran a los yndios como lo hazen los que mas pueden.

Finalmente, conviene que no aya de asiento españoles entre yndios porque les hazen muchos agravios $y$ ocupan en su servicio a muchos dellos $y$ les pagan poco $y$ harto ternan que hazir en acudir al tambo $y$ al trajin $y$ en cultivar sus chácaras y aumentar su ganado $y$ finalmente quando aya revisita se advertiran ds ctras cossas muy necesarias para el remedio de los ynciios. 
Par conclusion deste capitulo y tratado se note mucho $y$ muy mucho que una de las desgracias que este Reyno a tenido y tiene para que no se sepan estas cossas $Y$ otras muchas es que las mas de las personas graves $y$ de suerte que en el a crido y ay no saben mas dellas que si estubieran en España, porque los inquisidores y oydores que viven en lima solamente saben lo que oyen $y$ en sus ofticios tienen tanto que hacer que no es posible poderse enterar de raiz destas cossas particularmente siendo tan poquitos o ninguno los que puedan o quieran dar noticia dellas y los partidos que $\alpha \alpha v$. do en el Cuzco y la Plata eran tan biejos que el tiempo que vivieron no pudieron salir de sus casas y quando algun personaje grave pasa por estas provincias van tan de paso que no sabe dellas que si nunca las ubiera visto y todo su trato es con los correjidores $y$ algunos sacerdotes $y$ todo se va en cumplimientos y vanquetes y aunque algunos sacerdotes digan algo siempre son preferidos los corregidores que estan en lugar del Rey y como ellos hayan sido los que pretenden interes temporal informan en derecho de su lado nadie ay que diga las vejaciones y agravios que a los yndios se hacen particularmente las cossas que cometen los mismos corregidores y como estas personas son dé suerte no a de faltar indios en los tambos para su servicio que los buscan los corregidores debajo de la tierra y piensan que siempre es assi $y$ escriben a los Virreyes $y$ si es menester al rey que ay muchos yndios $y$ quien mejor conoce esto es el pobre pasajero a quien no se tienen estos respetos y si un virrey o el mismo rey quisiera tener noticia de todas las cossas que aqui van puestos $y$ de otras muchas mas en ninguna manera avia de embiar a nadie con nombre de Visitador o gobernador porque sin duda se le ocultarión muchas cossas y el servicio y recado que el allaría por los caminos pensaría que le abria siempre lo que se avia de hacer era embiar dos personas de grandissima confianza $y$ verdad $y$ que no tuesen conocidas $y$ tubiesen hacienda $y$ caudal $y$ se les prometiese una buena paga las quales andubiesen de por si de provincia en provincia y en cada una se detubiesen algunos meses $y$ que andubiesen como soldados pobres de manera que no se recatase nadie dellos $y$ por otra parte fuesen hombres de buen entendi miento $y$ muy esparcidos $y$ con esto ternian entrada con todos $y$ verion como tratan los corregidores y los agravios que hazen a los indios y las molestias que padecen cada día $y$ en los tambos verian lo que pasa y se enterarian de muchissimas cossas $y$ podria traer cada uno un escribano real consigo para que diese fee de lo que viesen y no solamente podrían enterarse muy de raiz de todas las cossas de los indios pero también de todas las demas del Perú que hacen los que tienen officios del Rey y si fuesen personas que no ubiesen estado en este reyno seria mejor porque notarian con mas advertencia muchas cossas que el uso y vellas cada dia hace que no se repara $\alpha$ los mas que $\alpha$ algun tiempo que estan aca y no faltaría quien con el secreto que era razon les advirtiese de muchas cossas para que con mas facilidad y brevedad se enterasen de todo lo que ay. Parece que los oydores de Chuquisaca podrian tener mas noticia destas cossas como la tienen y particularmente de las de Potosí pero lo mas que saben es de oydas y es muy diferente el concepto que dellas se tiene quando por vista de ojos se entera uno de los agravios y maltratamientos de los yndios y de otras cossas que ay $\mathrm{y}$ arto tienen que hacer en sus officios $\mathrm{y}$ satisfacer a tantos pleytos como tienen los negociantes. de las personas religiosas las más graves son los Provinciales $y$ visitadores $y$ estos son los que menos saben destas cossas, porque de ordinario assisten en Lima, que es como la orilla de España $y$ quando visitan sus conventos y doctrinas solamente se detienen lo que basta para enterarse de lo que ay y gobernar sus religiosos y proveer los superiores 
que a de aver y arto tienen que hacer en esto y si de otras cossas saben algo es de paso y a veces reciben pena de entendellas por el poco remedio que tienen y asi los dejon, de donde se sigue que en las consultas que con ellos se hacen en Lima podrán decir poco, porque si no hay mucha experiencia y conocimiento destas cossas con dificultad se dan los medios necesarios pa. ra remediar los daños que ay y hasta los mismos lectores de Teulogia se engañan quando confiesan un corregidor o otra persona que aya hecho las cossas arriba referidas porque quando digan que lo an vendido ha sido por lo que vale $Y$ que si an comprado algo a sido de la misma manera $y$ que an pagado a los yndios las cossas que an recibido dellos sino saben de la manera que hacen estas cossas pasaran de largo sin inquirillo $y$ en conclusion los que mas saben dellas son los que an vivido mucho tiempo entre indios y particularmente los de recta vida y exemplo conoceran mas desapasionadamente todo lo malo y assi los que podran dar mas puntual noticia y mejores medios para remediar todas estas cossas son muchos sacerdotes doctrinantes y en especial los de mejor entendimiento y de los de por aqui cerca de la Provincia de Chuquito los que an vivido on Nuestra Señora de Copacavana que son Padres Agustinos y también los que an vivido y asistido algun tiempo en Juli que son los Padres de la Compañía de Jesús, y muchos soldados $\mathrm{y}$ algunos escribanos que on vivido entre indios todos estos saben bien destas cossas y todos los demas, muy poco solamente por no aver vividos entre indios.

Dejólo quando murió el Pe. Antonio de Ayanz de la Compañía de Jesús.

(Continuaró). 